\title{
Deep, diverse and definitely different: unique attributes of the world's largest ecosystem
}

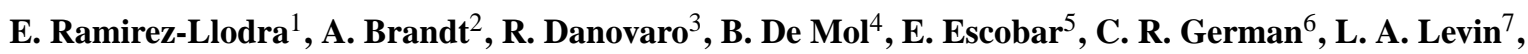 \\ P. Martinez Arbizu ${ }^{8}$, L. Menot $^{9}$, P. Buhl-Mortensen ${ }^{10}$, B. E. Narayanaswamy ${ }^{11}$, C. R. Smith ${ }^{12}$, D. P. Tittensor ${ }^{13}$, \\ P. A. Tyler $^{14}$, A. Vanreusel $^{15}$, and M. Vecchione ${ }^{16}$ \\ ${ }^{1}$ Institut de Ciències del Mar, CSIC. Passeig Marítim de la Barceloneta 37-49, 08003 Barcelona, Spain \\ ${ }^{2}$ Biocentrum Grindel and Zoological Museum, Martin-Luther-King-Platz 3, 20146 Hamburg, Germany \\ ${ }^{3}$ Department of Marine Sciences, Polytechnic University of Marche, Via Brecce Bianche, 60131 Ancona, Italy \\ ${ }^{4}$ GRC Geociències Marines, Parc Científic de Barcelona, Universitat de Barcelona, Adolf Florensa 8, 08028 Barcelona, Spain \\ ${ }^{5}$ Universidad Nacional Autónoma de México, Instituto de Ciencias del Mar y Limnología, A.P. 70-305 Ciudad Universitaria, \\ 04510 Mèxico, México \\ ${ }^{6}$ Woods Hole Oceanographic Institution, MS \#24, Woods Hole, MA 02543, USA \\ ${ }^{7}$ Integrative Oceanography Division, Scripps Institution of Oceanography, La Jolla, CA 92093-0218, USA \\ ${ }^{8}$ Deutsches Zentrum für Marine Biodiversitätsforschung, Südstrand 44, 26382 Wilhelmshaven, Germany \\ ${ }^{9}$ Ifremer Brest, DEEP/LEP, BP 70, 29280 Plouzane, France \\ ${ }^{10}$ Institute of Marine Research, P.O. Box 1870, Nordnes, 5817 Bergen, Norway \\ ${ }^{11}$ Scottish Association for Marine Science, Scottish Marine Institute, Oban, Argyll, PA37 1QA, UK \\ ${ }^{12}$ Department of Oceanography, University of Hawaii, 1000 Pope Road, Honolulu, HI 97822, USA \\ ${ }^{13}$ Department of Biology, Dalhousie University, Halifax, NS, Canada \\ ${ }^{14}$ National Oceanography Centre, University of Southampton, European Way, Southampton, SO14 3ZH, UK \\ ${ }^{15}$ University Ghent, Marine Biology, Krijgslaan 281, 9000 Ghent, Belgium \\ ${ }^{16}$ National Museum of Natural History, NMFS National Systematics Laboratory, Washington, DC, 20013-7012, USA
}

Received: 22 December 2009 - Published in Biogeosciences Discuss.: 7 April 2010

Revised: 13 September 2010 - Accepted: 15 September 2010 - Published: 22 September 2010

\begin{abstract}
The deep sea, the largest biome on Earth, has a series of characteristics that make this environment both distinct from other marine and land ecosystems and unique for the entire planet. This review describes these patterns and processes, from geological settings to biological processes, biodiversity and biogeographical patterns. It concludes with a brief discussion of current threats from anthropogenic activities to deep-sea habitats and their fauna.

Investigations of deep-sea habitats and their fauna began in the late 19th century. In the intervening years, technological developments and stimulating discoveries have promoted deep-sea research and changed our way of understanding life on the planet. Nevertheless, the deep sea is still mostly unknown and current discovery rates of both habitats and species remain high. The geological, physical and
\end{abstract}

Correspondence to: E. Ramirez-Llodra (ezr@icm.csic.es) geochemical settings of the deep-sea floor and the water column form a series of different habitats with unique characteristics that support specific faunal communities. Since 1840, 28 new habitats/ecosystems have been discovered from the shelf break to the deep trenches and discoveries of new habitats are still happening in the early 21 st century. However, for most of these habitats the global area covered is unknown or has been only very roughly estimated; an even smaller - indeed, minimal - proportion has actually been sampled and investigated. We currently perceive most of the deep-sea ecosystems as heterotrophic, depending ultimately on the flux on organic matter produced in the overlying surface ocean through photosynthesis. The resulting strong food limitation thus shapes deep-sea biota and communities, with exceptions only in reducing ecosystems such as inter alia hydrothermal vents or cold seeps. Here, chemoautolithotrophic bacteria play the role of primary producers fuelled by chemical energy sources rather than sunlight. Other ecosystems, such as seamounts, canyons or cold-water corals have an

Published by Copernicus Publications on behalf of the European Geosciences Union. 
increased productivity through specific physical processes, such as topographic modification of currents and enhanced transport of particles and detrital matter. Because of its unique abiotic attributes, the deep sea hosts a specialized fauna. Although there are no phyla unique to deep waters, at lower taxonomic levels the composition of the fauna is distinct from that found in the upper ocean. Amongst other characteristic patterns, deep-sea species may exhibit either gigantism or dwarfism, related to the decrease in food availability with depth. Food limitation on the seafloor and water column is also reflected in the trophic structure of heterotrophic deep-sea communities, which are adapted to low energy availability. In most of these heterotrophic habitats, the dominant megafauna is composed of detritivores, while filter feeders are abundant in habitats with hard substrata (e.g. mid-ocean ridges, seamounts, canyon walls and coral reefs). Chemoautotrophy through symbiotic relationships is dominant in reducing habitats.

Deep-sea biodiversity is among of the highest on the planet, mainly composed of macro and meiofauna, with high evenness. This is true for most of the continental margins and abyssal plains with hot spots of diversity such as seamounts or cold-water corals. However, in some ecosystems with particularly "extreme" physicochemical processes (e.g. hydrothermal vents), biodiversity is low but abundance and biomass are high and the communities are dominated by a few species. Two large-scale diversity patterns have been discussed for deep-sea benthic communities. First, a unimodal relationship between diversity and depth is observed, with a peak at intermediate depths $(2000-3000 \mathrm{~m})$, although this is not universal and particular abiotic processes can modify the trend. Secondly, a poleward trend of decreasing diversity has been discussed, but this remains controversial and studies with larger and more robust data sets are needed. Because of the paucity in our knowledge of habitat coverage and species composition, biogeographic studies are mostly based on regional data or on specific taxonomic groups. Recently, global biogeographic provinces for the pelagic and benthic deep ocean have been described, using environmental and, where data were available, taxonomic information. This classification described 30 pelagic provinces and 38 benthic provinces divided into 4 depth ranges, as well as 10 hydrothermal vent provinces. One of the major issues faced by deep-sea biodiversity and biogeographical studies is related to the high number of species new to science that are collected regularly, together with the slow description rates for these new species. Taxonomic coordination at the global scale is particularly difficult, but is essential if we are to analyse large diversity and biogeographic trends.

Because of their remoteness, anthropogenic impacts on deep-sea ecosystems have not been addressed very thoroughly until recently. The depletion of biological and mineral resources on land and in shallow waters, coupled with technological developments, are promoting the increased interest in services provided by deep-water resources.
Although often largely unknown, evidence for the effects of human activities in deep-water ecosystems - such as deepsea mining, hydrocarbon exploration and exploitation, fishing, dumping and littering - is already accumulating. Because of our limited knowledge of deep-sea biodiversity and ecosystem functioning and because of the specific lifehistory adaptations of many deep-sea species (e.g. slow growth and delayed maturity), it is essential that the scientific community works closely with industry, conservation organisations and policy makers to develop robust and efficient conservation and management options.

\section{Introduction}

\section{Exploration of the last frontier on earth}

Although the largest ecosystem on Earth, the deep ocean is also the least explored and understood. The oceans cover $71 \%$ of the planet's surface, with $50 \%$ below $3000 \mathrm{~m}$ depth and a mean depth of $3800 \mathrm{~m}$. Only $5 \%$ of the deep sea has been explored with remote instruments and less than $0.01 \%$ of the deep sea-floor (the equivalent of a few football fields) has been sampled and studied in detail. Nevertheless, what little we know indicates that the deep sea supports one of the highest levels of biodiversity on Earth (Hessler and Sanders, 1967; Sanders, 1968; Grassle and Macioleck, 1992; Etter and Mullineaux, 2001; Snelgrove and Smith, 2002; Stuart et al., 2003), as well as important biological and mineral resources (UNEP, 2007; Baker and German, 2009). Whereas the surface waters have played a central role in the development of human civilization, being used for transport of goods and people, fishing and leisure, recently the development of marine technologies have allowed us to enter the depths of the oceans, to explore, investigate and exploit its resources.

The first record of deep-sea fauna, the ophiuroid Gorgonocephalus caputmedusae (as Astrophyton linckii), was collected by Sir John Ross in 1818, while dredging at $1600 \mathrm{~m}$ during his exploration for the Northwest Passage (Menzies et al., 1973). This discovery remained hidden and when Edward Forbes, dredging in the Aegean down to $420 \mathrm{~m}$ depth (H. M. S. Beacon, 1841-1842), found fewer species with increasing depth, he concluded that no life was present in the oceans below $600 \mathrm{~m}$ in what became known as the "Azoic Theory" (Forbes, 1844). This theory stimulated debate and investigation. In the years that followed, evidence of life in deep-sea systems accumulated. Some of the most relevant examples include the deep-water species list published by M. Sars and his son G. O. Sars from below $600 \mathrm{~m}$ depth and the sampling of the solitary coral Caryophyllia borealis by F. Jenkin on a submarine cable from $2184 \mathrm{~m}$ in the Mediterranean. The increasing evidence stimulated the organisation of deep-sea expeditions in the Atlantic and Mediterranean in the late 1860s on board H. M. S. Lightning and H. M. S. Porcupine, leading finally 
to the H. M. S. Challenger circumglobal expedition (18721876 ) led by C. W. Thomson to study physical, chemical and biological processes in the deep ocean. This cruise is considered to mark the birth of modern oceanography (Murray and Hjort, 1912; Menzies et al., 1973). There then followed a period of intense scientific activity in the deep sea, sometimes known as the "heroic age", where the deep ocean was sampled systematically, making important contributions in the improvement of deep-sea techniques and greatly extending the taxonomic knowledge of deep-sea fauna. This era of exploration culminated in the Galathea expedition (19501952) that collected live animals from the greatest ocean depths in the Philippines Trench, at $10190 \mathrm{~m}$ depth (Gage and Tyler, 1991). With the exception of anoxic deep-sea environments such as the Black Sea, animals were living at all depths in the ocean.

In the 1960s and 1970s, deep-sea research moved from description to an ecological and experimental approach, with the introduction of sampling equipment such as the boxcorer and epibenthic sled to obtain quantitative samples of deep-sea communities (Hessler and Sanders, 1967; Grassle and Sanders, 1973; Grassle, 1977; Sanders, 1979) and developing sample-size independent statistical approaches to facilitate inter-sample comparison (Sanders, 1968). Nevertheless, the conquest of the oceans could not be complete without the development of means of observing, exploring and experimenting in situ. Parallel to the remarkable developments in navigation and oceanographic technologies, there is the history of diving, from the diving bells used in the 17 th century for short dives in shallow waters (down to $18 \mathrm{~m}$ ) to Beebe's Bathysphere in 1930, the first deepwater vehicle for observation of the seabed (Beebe, 1939; Sweeney, 1970; Ballard, 2000). In little more than 50 years, the advances in deep-sea technology have led to the development of modern-day submersibles, Remotely Operated Vehicles (ROVs), Autonomous Underwater Vehicles (AUVs) and deep-sea permanent observatories, with ever increasing capabilities for exploration, sampling and experimentation (Gage and Tyler, 1991; German et al., 2008). The last 3 decades have been marked by the discoveries of unique habitats, such as hydrothermal vents, cold seeps, whale falls and cold-water corals, and by significant improvements in our understanding of the biodiversity and functioning of deep-sea ecosystems. These discoveries have been made possible only through technological developments and international collaboration.

This review is the result of a coordinated international effort in the framework of the Census of Marine Life deep-sea synthesis project SYNDEEP. The focus is to describe major abiotic and biotic characteristics that make the deep sea a unique environment. Our goals are to (a) describe the geological settings of deep-sea habitats that sustain specific faunal communities, (b) explain productivity issues and their effects on deep-sea fauna composition, (c) discuss metazoan community composition and structure and biodiversity patterns specific to deep-sea ecosystems, and (d) describe current anthropogenic threats to deep-sea systems. The review focuses on metazoan organisms, while deep-sea microbial diversity patterns and function have been covered in other recent reviews, both for pelagic (Sogin et al., 2006; Arítstegui et al., 2009) and benthic microbes (Jorgensen and Boetius, 2007). Furhthermore, much of our knowledge of the deep sea is based on benthic sampling, particularly using deepdiving research submersibles. By contrast, substantially less effort has been made toward sampling pelagic metazoans, mainly because the difficulty of sampling these communities is much in the huge volume of the deep-pelagic environment. Accordingly, the balance of this review directly reflects the relative efforts that have been expended within the scientific community to-date to study these two systems. That said, we recognize that it is the deep-ocean pelagic realm that provides the far larger continous habitat and a detailed understanding of this realm will continue to present an important future challenge for marine biology.

\section{Unique geological settings that shape unique deep-sea habitats}

\subsection{Habitat discovery rate}

The deep ocean hosts a wide diversity of geological and ecological settings that might not be apparent to the casual observer sailing across the surface of these deep waters (Fig. 1). Taking Forbes' dredging cruise in 1842 as the start of deepsea research, twenty-two new deep-sea habitats and ecosystems have been discovered in the past 170 years (Table 1). This is an average of 1 new habitat every 8 years. However, discoveries have not occurred at a constant rate. Figure 2 shows the discovery rate of new geological features, ecosystems or specific habitats since Forbes. The graph suggests 3 distinct periods of discovery. The first period, between 1840 and 1880 reflects the pioneer work conducted in the deep sea from Forbes to the Albatross cruise that sampled trenches for the first time. In the next 50 years, the rate of deep-sea discoveries decreased, reflecting both technological limitations to explore and sample accurately the deep seafloor and world conflicts such as the two world wars. Since the 1940s, new habitats and ecosystems have been described and investigated at an increased pace, with a particularly intense discovery period in the last 30 years, when chemosynthetic ecosystems, including vents, seeps and whale falls, were found. This increase in discoveries was facilitated by significant technological developments, such as the improvement of remote sensing using hull-mounted and towed side-scan sonars for high resolution bathymetry mapping and, in particular, the use of submersibles, ROVs and AUVs for direct exploration and experimentation. 


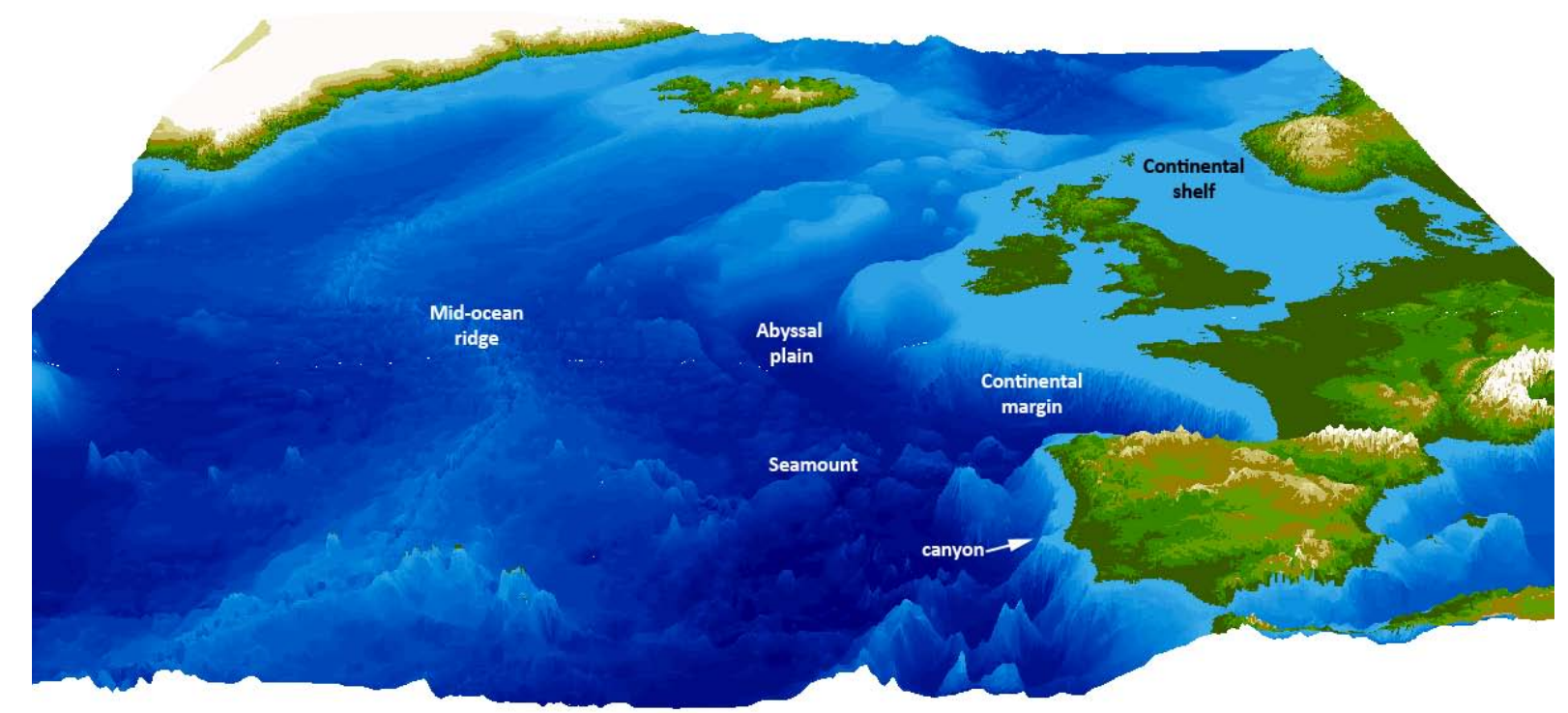

Fig. 1. The NE Atlantic seafloor showing some of the distinct deep-sea ecosystems: continental margins (which can include canyons - arrow, cold seeps and cold water corals), abyssal plains, seamounts and the mid-ocean ridge, where hydrothermal vents are found. () Åge Høines, MAR-ECO.

Table 1. Year of discovery of new habitats and/or ecosystems from Forbe's Azoic Theory to date. OMZ, Oxygen Minimum Zone; MOR, Mid-Ocean Ridge.

\begin{tabular}{lcl}
\hline Deep-sea habitat & Year & Reference \\
\hline Fine sediment $(400 \mathrm{~m})$ & 1840 & Forbes, 1844 \\
Fine sediment $(600 \mathrm{~m})$ & 1849 & Sars, 1849 \\
Fine sediment $(2000 \mathrm{~m})$ & 1862 & Jenkin, 1862 \\
Submarine canyons & 1863 & Dana, 1863 \\
Seamounts (geologic feature) & 1869 & Ankarcrona, 1869 \\
Sponge fields & 1870 & Thomson, 1873 \\
Open water & 1876 & Challenger Report, 1885 \\
Fine sediment (abyssal) & 1876 & Challenger Report, 1885 \\
Manganese nodules & 1876 & Challenger Report, 1885 \\
Cold-water corals (as distinct ecosystem) & 1922 & Broch, 1922 \\
OMZ pelagic & 1925 & Hentschel, 1936 \\
OMZ benthic & 1928 & Spiess, 1928 \\
Whale falls (as source of food) & 1934 & Krogh, 1934 \\
Mud volcanoes & 1934 & Chhibber, 1934 \\
Trenches & 1948 & Belyaev, 1989 \\
Wood falls & 1952 & Galathea Report, 1956 \\
MOR (as spreading ridges) & 1963 & Vine and Mathews, 1963 \\
Back-arc basins & 1971 & Karig, 1971 \\
MOR (fast spreading) & 1977 & Lonsdale, 1977 \\
Xenophyophore fields & 1979 & Rice et al., 1979 \\
Deep hypersaline anoxic basins & 1983 & Jongsma, 1983 \\
Cold seeps & 1984 & Paull et al., 1984 \\
MOR (slow spreading) & 1986 & Rona et al., 1986 \\
Whale falls (as chemosynthetic habitat) & 1989 & Smith et al., 1989 \\
Brine pool (as chemosynthetic habitat) & 1990 & MacDonald et al., 1990 \\
Asphalt habitat (Chapopote) & 2004 & MacDonald et al., 2004 \\
Large bare rock region South Pacific & 2006 & Rea et al., 2006 \\
\hline & & \\
& & \\
\hline
\end{tabular}

Biogeosciences, 7, 2851-2899, 2010

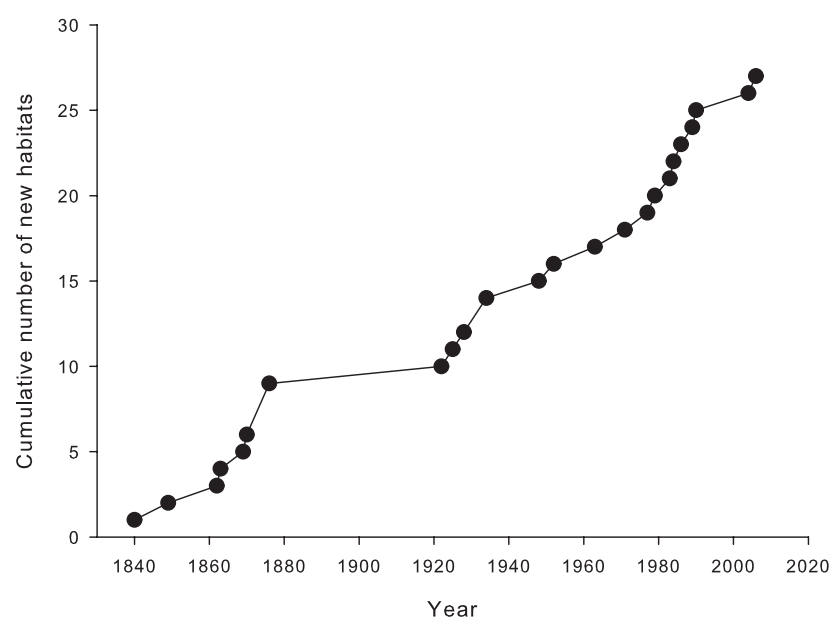

Fig. 2. Habitat discovery rate from Forbes' Azoic theory to date. For details of habitats considered, see Table 1.

\subsection{Habitat coverage}

Of the 510 million $\mathrm{km}^{2}$ of Earth's surface, 362 million $\mathrm{km}^{2}$ are ocean seafloor, with roughly $90 \%$ of the oceans being deep sea. The deep seafloor is formed by hundreds of millions of kilometres square of continental slope and abyssal plains. Embedded within these slopes and deep basins are other geological structures, including mid-ocean ridges, canyons, seamounts, cold-water coral reefs, hydrothermal vents, methane seeps, mud volcanoes, faults and trenches, which support unique microbiological and faunal communities. The deep-sea pelagic environment is even larger, 
adding a third dimension (depth). Familiar terrestrial life is tightly bound to the surface of the land, with interactions amongst organisms essentially two dimensional. In contrast, the pelagic is a three-dimensional environment, most of which has little or no direct interaction with the interfaces at the ocean's bottom and surface. The deep-sea pelagic encompasses over 1 billion $\left(1 \times 10^{9}\right) \mathrm{km}^{3}$ (Herring, 2002), with animals and microbes growing, feeding and reproducing throughout that volume (Robison, 2008). Unlike air, the density of water allows organisms to attain neutral buoyancy that frees them from the restraint of life on the bottom.

The exact coverage of each different deep-sea habitat is not known, as the vast bulk of the deep sea remains unexplored. However, from present geological and geochemical knowledge, accurate bathymetry and remote sensing, we are able to provide estimates of area coverage for each habitat, extrapolated from available data (Table 2). Of the benthic systems, the abyssal plains account for $76 \%$ of the seafloor, followed by continental margins (10\%) and the ridge system (9\%). Seamounts (2.6\%) and trenches (2\%) also comprise a significant part of the seafloor, while other habitats such as vents, seeps, whale falls, benthic Oxygen Minimum Zones (OMZ) and cold-water corals are much smaller and localised. Because of the smaller global area coverage, the proportion of these latter ecosystems that has been explored and investigated is relatively significant (up to 10\%) compared to the unknown expanses of abyssal plains and continental margins $(<1 \%)$ (Table 2).

\subsection{Deep-sea volcanic chains}

Mid-ocean ridges, a linear range of volcanic mountains, extend 50-60000 km across the floor of the ocean basins. The new ocean crust that is formed there is relatively thin (about $6 \mathrm{~km}$ thick on average) when compared to continental crust (typically $20-30 \mathrm{~km}$ thick), which can be significantly thicker in large mountain chains such as the Himalayas ( $>50 \mathrm{~km}$ thick and sometimes up to $70 \mathrm{~km}$ ). By contrast, it is rare to find ocean crust on the seafloor that is thicker than $7 \mathrm{~km}$, with obvious exceptions found where ocean geophysical hotspots raise the seafloor, some to above sea level in places like Iceland in the North Atlantic and Hawaii in the central Pacific. Along mid ocean ridges, about $3 \mathrm{~km}^{2}$ of new seafloor is generated each year (OU, 1998).

On mid-ocean ridges, the variability of habitats for life is striking (Holland et al., 2005; Vinogradov, 2005). Here, we find rocky substratum exposed in the middle of the deep ocean resulting in a rugged terrain that includes a variety of habitats, from hills and seamounts a few hundred meters deep, to axial valleys and fracture zones dropping to more than $4000 \mathrm{~m}$ depth and often covered with sediment (Bergstad et al., 2008). The presence of these ridges affects the distribution of both pelagic and bathyal organisms. The rocky substratum contrasts with the surrounding abyssal plains, providing habitat for a variety of sessile fauna, many of which are filter feeders taking advantage of specific hydrographic conditions created around the ridge. Productivity over the ridge is a major factor influencing patterns of megafaunal abundance and distribution (King et al., 2006; Bergstad et al., 2008). In addition, a very specific environmental niche was discovered along the young volcanicallyformed seafloor of the mid-ocean ridges in the late 1970s: the submarine hydrothermal vents. These arise when cold oxygenated seawater seeps down into, and reacts with fresh ocean crust to generate hot (up to $407^{\circ} \mathrm{C}$ ), chemically-laden fluids (Corliss et al., 1979). A unique type of habitat is found here (Van Dover, 2000; Tyler et al., 2003), fuelled by energy released by chemical reactions rather than the input of energy in the form of photons from the sun (see Sect. 3.2).

\subsection{The great expanse: abyssal plains}

The regions of ocean crust where slopes and ridge flanks flatten out represent perhaps the single largest contiguous feature of our planet and also the least explored: the extensive abyssal plains (Smith et al., 2008; Ebbe et al., 2010). Abyssal sediments consist of terrigenous particles derived from rock weathering on land as well as biological particles produced in the surface layers by plancktonic organisms. The latter can be siliceous if formed from diatoms, silicoflagellates and radioloarians, or calcareous from foraminiferans, pteropods and coccolithophores (Thistle, 2003). The sediment layer covering abyssal plains can reach thousands of meters in thickness and is mostly inorganic, excluding the top layers that receive organic input from the water column. Some of the major abiotic characteristics of abyssal plains are relatively uniform: temperature is $\sim 2{ }^{\circ} \mathrm{C}$ (except in the Mediterranean $-14{ }^{\circ} \mathrm{C}-$ and Red Sea $-21^{\circ} \mathrm{C}$ ); salinity is $\sim 35 \%$ o (except in the Mediterranean and Red sea $>39 \%$ ) ; dissolved oxygen is near saturation: $5-6 \mathrm{ml} \mathrm{l}^{-1}$ (except in OMZs); pressure increases at 1 atmosphere every $10 \mathrm{~m}$ depth; and photosynthetically useful light is absent below $\sim 200 \mathrm{~m}$. Based on these parameters, abyssal plains were long considered to be constant and stable environments where physical and biological processes were unchanged over short and long time-scales. However, evidence accumulated since the 1960s has shown that the deep sea is in fact a dynamic environment (reviewed by Tyler, 1988; Gage, 2003) with regular (e.g. tidal currents, seasonal deposition of phytodetritus) and episodic disturbances (e.g. benthic storms) that affect the benthic fauna in some regions. The seasonal deposition of phytodetritus under productive areas (Billett et al., 1983; Lampitt, 1985; Thiel et al., 1990; Smith et al., 1996; Lampitt and Antia, 1997; Beaulieu and Smith, 1998) provides abyssal communities with a high-quality food resource that triggers specific responses from the fauna, such as opportunistic use of the food and seasonal reproduction (reviewed in Tyler, 1988; Ramirez-Llodra, 2002; Gage, 2003; Young, 2003). Although visually similar to a desert, with only a few obvious detritus feeders (e.g. holothurians) and 
Table 2. Area coverage (known or estimated) of the major deep-sea habitats, with indications of the proportion of ocean floor covered and the proportion that has been investigated to date.

\begin{tabular}{|c|c|c|c|c|}
\hline Habitat & Area $\left(\mathrm{km}^{2}\right)$ & $\begin{array}{r}\% \text { of ocean } \\
\text { floor }\end{array}$ & $\begin{array}{r}\text { Proportion } \\
\text { investigated }\end{array}$ & References \\
\hline $\begin{array}{l}\text { Deep water } \\
\text { (pelagic) }\end{array}$ & $\begin{array}{r}1000000000 \\
\mathrm{~km}^{3}\end{array}$ & $\begin{array}{r}73 \% \text { of water } \\
\text { in oceans }\end{array}$ & $<<0.0001 \%$ & $\begin{array}{l}\text { Herring, 2002; } \\
\text { M. Vecchione, personal } \\
\text { communication, } 2009\end{array}$ \\
\hline Deep seafloor & $\begin{array}{r}326000000 \\
\mathrm{~km}^{2}\end{array}$ & $100 \%$ & $0.0001 \%$ & Tyler, 2003 \\
\hline Abyssal plains & $\begin{array}{r}244360000 \\
\mathrm{~km}^{2}\end{array}$ & $75 \%$ & $<1 \%$ & Gerlach, 1994 \\
\hline $\begin{array}{l}\text { Continental } \\
\text { slope ( } 150 \text { to } \\
3500 \mathrm{~m} \text { depth) }\end{array}$ & $\begin{array}{r}40000000 \\
\mathrm{~km}^{2}\end{array}$ & $11 \%$ & minimal & $\begin{array}{l}\text { L. Menot, } \\
\text { unpublished } \\
\text { data }\end{array}$ \\
\hline Ridges & $\begin{array}{r}55000 \mathrm{~km} \text { long. } \\
30000000 \\
\mathrm{~km}^{2} \text { (young } \\
\text { crest }<1 \text { myr) }\end{array}$ & $9.20 \%$ & $10 \%$ & $\begin{array}{l}\text { Area: German, } \\
\text { estimated from } \\
\text { German et al. } \\
\text { (2004). } \\
\text { Exploration: } \\
\text { Baker and } \\
\text { German, } 2004\end{array}$ \\
\hline Seamounts & $\begin{array}{r}8500000 \\
\mathrm{~km}^{2}\end{array}$ & $2.6 \%$ & $\begin{array}{r}0.25-0.28 \% \\
(250-280 \\
\text { seamounts } \\
\text { sampled of ca. } \\
100000)\end{array}$ & $\begin{array}{l}\text { Seamounts } \\
\text { Online, } 2009 \\
\text { http://seamounts } \\
\text {.sdsc.edu }\end{array}$ \\
\hline Hadal zone & $\begin{array}{r}37 \text { trenches } \\
(\text { area not } \\
\text { estimated })\end{array}$ & $1 \%$ & minimal & $\begin{array}{l}\text { Blankenship- } \\
\text { Williams and } \\
\text { Levin, } 2009\end{array}$ \\
\hline Canyons & $\begin{array}{r}448 \text { canyons } \\
\text { with a total } \\
\text { estimated } \\
\text { lenght of } \\
25000 \mathrm{~km} . \\
\text { Area } \\
\text { unknown. }\end{array}$ & unknown & minimal & $\begin{array}{l}\text { Estimated from } \\
\text { Shepard and } \\
\text { Dill, 1966 } \\
\text { and GEBCO }\end{array}$ \\
\hline $\begin{array}{l}\text { OMZ } \\
\text { (benthic) }\end{array}$ & $\begin{array}{r}1148000 \\
\mathrm{~km}^{2}\end{array}$ & $0.35 \%$ & $<1 \%$ & $\begin{array}{l}\text { Helly and } \\
\text { Levin, } 2004\end{array}$ \\
\hline $\begin{array}{l}\text { Cold-water } \\
\text { coral reefs }\end{array}$ & $\begin{array}{r}\text { estimated } \\
280000 \mathrm{~km}^{2}\end{array}$ & $0.08 \%$ & minimal & $\begin{array}{l}\text { UNEP, } \\
\text { http://www.unep } \\
\text {.org/cold_water } \\
\text { _reefs/comparison } \\
\text {.htm }\end{array}$ \\
\hline $\begin{array}{l}\text { Hydrothermal } \\
\text { vents }\end{array}$ & $\begin{array}{r}\text { Approx. } 2000 \\
\text { vents. Area } \\
\text { unknown. }\end{array}$ & unknown & $\begin{array}{r}10 \%(200 \\
\text { known vents } \\
\text { of ca. } 2000)\end{array}$ & $\begin{array}{l}\text { German et al., } \\
2004\end{array}$ \\
\hline
\end{tabular}


Table 2. Continued.

\begin{tabular}{|c|c|c|c|c|}
\hline Habitat & Area $\left(\mathrm{km}^{2}\right)$ & $\begin{array}{r}\% \text { of ocean } \\
\text { floor }\end{array}$ & $\begin{array}{r}\text { Proportion } \\
\text { investigated }\end{array}$ & References \\
\hline Cold seeps & $10000 \mathrm{~km}^{2}$ & $0.003 \%$ & $2 \%$ & $\begin{array}{l}\text { E. E. Cordes, personal } \\
\text { communication, } 2009\end{array}$ \\
\hline Whale falls & $\begin{array}{r}\sim 35 \mathrm{~km}^{2} \\
(690000 \\
\text { whale falls } \\
\text { with ca. } 50 \\
\left.\mathrm{~m}^{2} \text { per fall }\right)\end{array}$ & $0.00001 \%$ & $\begin{array}{r}0.005 \%(\sim 30 \\
\text { out of } 690000 \\
\text { estimated } \\
\text { sulfide-rich } \\
\text { whale falls })\end{array}$ & $\begin{array}{l}\text { Smith and Baco, } \\
\text { 2003; Smith, } \\
\text { 2006; Treude et } \\
\text { al., } 2009\end{array}$ \\
\hline
\end{tabular}

scavengers (e.g. crustaceans and demersal fish), the top centimetres of sediments of abyssal plains are colonised by very rich communities of macro- and meiofauna with very high biodiversity levels (see Sect. 5.1 and 5.2).

Much of the sediment-covered abyssal seafloor is characterized by sluggish bottom currents and little current scouring. However, beneath western boundary currents such as the Gulf Stream, the Kuroshio and the East Australian Current, bottom flow can reach relatively high velocities and scour sediments to ocean depths of $\sim 1500 \mathrm{~m}$ along the continental slope. Where the western boundary currents turn eastward into the open ocean, losing the steering effects of the continental slope, current meanders and high eddy energy may be generated to great depths (Tomczak and Godfrey, 1994), producing intermittent currents capable of eroding fine sediments at $4000 \mathrm{~m}$ on the abyssal seafloor (Hollister and McCave, 1984). One abyssal area characterized by high flows has been studied in the northwest Atlantic during the HEBBLE project (Hollister and McCave, 1984). In the HEBBLE study area, benthic communities are characterized by unusually high abundances of bacteria and macrofauna, compared to other deep-sea areas, possibly related to enhanced food flux associated with the currents (Thistle et al., 1985, 1991). Community structure is also unusual in that juveniles dominate many macrofaunal populations and sediment-surface dwelling crustaceans are much less abundant than in other deep-sea areas, presumably as a consequence of physical disturbance from sediment erosion (Thistle et al., 1991; Thistle and Wilson, 1987, 1996). Slope and abyssal areas characterized by such currents of erosive magnitude could cover $\sim 10 \%$ of the deep seafloor (Hollister and McCave, 1984).

\subsection{Diversity of habitats on continental margins}

The most geologically diverse components of the deep-ocean floor are continental margins, with high habitat heterogeneity (Levin and Dayton, 2009; Menot et al., 2010; Levin et al., 2010a). Initially, margins can be divided into active and passive. Passive margins occur where an ocean rift has split two parts of a continent in two, generating an ocean basin in between. This process can be seen in its infancy today in the Red Sea where the Arabian subcontinent is being separated from Africa. Other, better established examples include the West Coast of India and the East Coast of Africa, which are being pushed apart by the Central Indian Ridge at a rate of $\sim 4 \mathrm{~cm} / \mathrm{yr}$, and in the Atlantic, where the eastern margins of North and South America and the western margins of Europe and Africa are separating at $2-3 \mathrm{~cm} / \mathrm{yr}$. Along the lengths of these ocean margins, habitats for life can be extremely diverse, affected by processes such as the composition of the continental rocks that abut the ocean seafloor and predate the ridge formation, the topography of the adjacent land masses that influence detrital sediment delivery rates, the productivity and seasonality of the overlying surface ocean that constrains the supply of nutrients, and availability of oxygen in the deep waters. In addition to all of these processes, a range of subsurface and sub-seafloor geological processes can also influence the environment. These include run-out of groundwater discharge that escapes from the continents into the oceans below the seabed along submerged aquifers, as well as through rivers and estuaries. Processes associated with maturation of buried organic matter as it becomes compressed and heated under layer upon layer of sediments also have an effect in the habitat. These processes give rise to flows of chemically altered fresh- and saltwater and include methane release from cold seeps (Sibuet and Olu, 1998; Levin, 2005), destabilization of gas hydrates and much more viscous flows such as oil seeps, asphalt eruptions (MacDonald et al., 2004) and, in the extreme, large mud volcanoes (Mikov, 2000). The geological and geochemical characteristics of the environment result in the formation of distinct habitats, including sedimentary slopes, submarine canyons that form conduits of particles from the shelf to the deep basin, cold-water corals that form reefs in the absence of sunlight and cold seeps and asphalt eruptions that support chemosynthetically-based communities. The specific biological process and patterns that single out these ecosystems are described in Sects. 3 and 5.

Along active margins, the variability of habitats for life is even more striking. Such margins are found where the ocean floor has cooled so extensively that it becomes too dense to continue to float across the underlying ductile mantle 
and it sinks back into the Earth's interior, forming deepocean trenches along subduction zones. Subduction zones extend almost the entire length of the East Pacific margin from the southernmost tip of Chile to the Aleutian Islands of Alaska and along the western margin of the Pacific, too, from the Kamchatka margin of NE Russia to the southern tip of the South Island of New Zealand. Along these margins, three distinct geological systems can arise. First, deepocean trenches form slivers of narrow, elongate ocean floor that plunge from depths of $6000 \mathrm{~m}$ to $>10000 \mathrm{~m}$ deep. Indeed, the deepest trenches fall farther below the sea surface than mountain ranges extend high: Mount Everest, flipped upside down, could be swallowed up in the Challenger Deep of the Marianas Trench with a couple of kilometres of seawater to spare. As an ocean plate sinks beneath the seafloor, some of the material is carried down and melts, leading to chains of volcanoes immediately beyond the line of subduction (OU, 1998). When this process happens close to a continent, massive sub-aerial mountain chains occur such as the Andes of South America, the southern Alps of New Zealand or the Cascade mountains of the United States' Pacific Northwest. When the same subduction process happens at sea, the volcanic activity that results can generate large islands such as Sakhalin Island and Japan. More typically, this results in an archipelago of smaller volcanic constructs, some of which may rise high enough above the seafloor to form islands interspersed with submerged volcanoes, termed seamounts. Excellent examples of such "island arcs" are seen along the Marianas Islands, the Tongan archipelago and the Isu-Bonin arc of the west Pacific. A final subset of geologic terrain associated with active margins lies beyond the island arcs of ocean-ocean subduction zones. Here, as oceanic crust is distorted by the forces of two tectonic plates colliding, rupturing occurs that allows fresh lavas to erupt onto depressions in the seafloor. These are the back-arc basins, which in essence represent something akin to mid-ocean ridges in miniature and the same combination of habitats for life as on mid-ocean ridges applies (Desbruyères et al., 2007).

\subsection{Chapopote: asphalt eruption habitats}

Hydrocarbon seepage is in general an abundant phenomenon in the southern Gulf of Mexico (GoM). In 2003, fluid and gas venting were investigated in several GoM knolls, in relation to asphalt volcanism (MacDonald et al., 2004; Brüning et al., 2010). The uniqueness of these systems is the episodic intrusions of semi-solid hydrocarbons that spread laterally over an extended area, producing structures with significant vertical relief. Chapopote belongs to the type of knolls with pronounced crater-like structures (300-400 $\mathrm{m}$ in diameter). Asphalt volcanism in the southern GoM is a secondary result of salt tectonism and differs from oil and gas seepage previously known. Results obtained from seafloor imagery, mapping of individual flows and faults and recovered samples indicate that the asphalt deposits originate from seepage of heavy petroleum, which, as it is released, forms characteristic flow structures at the seafloor with surfaces similar to magmatic lava flows. Temperature measurements showed that the temperature is similar to the bottom water temperature (Ding et al., 2008).

The asphalts present diverse types of forms, from fresh gooey and sticky asphalt, to older, brittle fragmented pieces that underwent processes of volume reduction leading to the formation of visible cracks in the asphalt surface and fragmentation of the entire deposit. These asphalts occur with different generations of asphalt flows and support chemosynthetically-driven faunal communities. Petroleum seepage from below the asphalt deposits occur promoting local heterogeneity of microhabitats with up-doming of the seafloor and whip-shaped extrusion structures. The asphalt deposits occur at the south-western rim bordering the central, crater-like depression. The most recent asphalt deposit at Chapopote is the main asphalt field covering an area of $\sim 2000 \mathrm{~m}^{2}$. The main asphalt field is probably over twenty years old, based on maximum length of the vestimentiferan tubeworms observed and age determination methods for this group (Cordes et al., 2003).

\subsection{Seamounts}

Seamounts are topographically-isolated peaks rising more than $1000 \mathrm{~m}$ above the surrounding seabed (Rogers, 1994; Consalvey et al., 2010; Schlacher et al., 2010), often with a rocky substratum that is quite distinct from the sedimented deep-ocean floor. Few seamounts have been mapped, but satellite gravimetry data and modern mapping has already revealed more than 100000 seamounts that rise more than $1000 \mathrm{~m}$ above the surrounding deep-ocean floor (Koslow et al., 2001; Kitchingman and Lai, 2004). Long chains of such seamounts can also occur as the trace of "hotspots" - locales at which plumes of anomalously hot and buoyant material rise from deep within the Earth's mantle and score a trail across the floor of the over-riding tectonic plate. Perhaps the clearest and most familiar example of such a process is found in the Hawaiian Islands in the central North Pacific and Tahiti and the associated Society Islands of the South Pacific. Even in these famous sub-aerial examples, however, much of the activity - and associated habitats - lies in the submarine deep-ocean environment. For example, the youngest and most volcanically active of the Hawaiian Islands lies to the southeast of this island chain, but even farther southeast we find the volcanically and hydrothermally active Loihi seamount (Malahoff, 1987). This seamount, at its shallowest, approaches within $1000 \mathrm{~m}$ of the ocean surface, hence several thousands of meters above the floor of the Pacific abyssal plain. This presently is the point at which the Pacific Plate sits directly above the Hawaiian hot-spot plume, but as the plate continues to migrate further to the northwest, given enough time and volcanic activity, new seamounts and additional Hawaiian Islands will emerge. Conversely, to the 
northwest, as the various islands migrate further from the influence of the hotspot and become dormant, eustatic subduction and sub-aerial erosion will wear these islands away until they sink beneath the ocean surface once more. The exception would be when, given the correct combination of water quality, sunlight and nutrient supply, coral reefs will overgrow the submerging rocky substratum and then continue to grow upward toward the sunlit upper ocean, keeping pace with the rates at which the otherwise passive rocky substratum would subside beneath the waves. The specific topography of seamounts creates distinct habitats elevated from the ocean floor, characterised by particular hydrography, substratum types and productivity that influences the diversity of the fauna and functioning of the ecosystem (see Sect. 3.4).

\subsection{Trenches}

The term "deep-sea trench" not only refers to a habitat in a certain depth range (e.g. below abyssal depths at $>6000 \mathrm{~m}$ ), but it corresponds also to a specific geo-morphological feature of the seafloor, which includes certain trenches at depths less than $6 \mathrm{~km}$. The Mediterranean basin includes the Hellenic trench south of Crete with depths close to $4000 \mathrm{~m}$. By the mid 1950s, it was already evident that the deep-ocean troughs at depths $>6-7 \mathrm{~km}$ were unique and therefore should be differentiated from the abyssal habitats. The trench crossprofiles have a characteristic V-shape and the seafloor relief is typically characterized by extreme topographic complexity, with narrow, flat floor and terraces where some fine sediment preferentially accumulates (Belyaev, 1989). Moreover, trenches are typically very narrow and their width generally does not exceed $40 \mathrm{~km}$. Their slopes can be up to $45^{\circ}$ or more, making trenches extremely difficult to sample remotely. The trench floor is characterized by fine-grained non-calcareous sediments. Currents near the bottom have velocities that range from 10 to $32 \mathrm{~cm} \mathrm{~s}^{-1}$ (at $9800 \mathrm{~m}$ depth). Trenches are often characterized by the presence of turbidity currents, slides and collapses that can have catastrophic consequences on the local benthos. One of the main factors that characterises the hadal systems is the high hydrostatic pressure, which at these depths reaches 600-1100 atmospheres. For organisms inhabiting almost $98.5 \%$ of the ocean floor, these pressures are beyond tolerable conditions. Conversely, temperature, salinity and oxygen content in trenches are not so different from abyssal habitats. Temperature in hadal systems are stable and typically close to $2{ }^{\circ} \mathrm{C}$ (ranging from -0.3 to $4.5^{\circ} \mathrm{C}$; Belyaev, 1989). The only exception is the shallower Mediterranean Hellenic Trench, where temperature remains close to $14^{\circ} \mathrm{C}$ (Tselepides and Lampadariou, 2004). Temperature range within each trench does not exceed $0.9^{\circ} \mathrm{C}$ and temperature might slightly increase with increasing depth (adiabatic temperature rise). Water temperature at hadal depths could be higher than at abyssal depths in the same region. The salinity is similar to that of abyssal regions: ca. $34.7 \pm 0.2$. Oxygen concentrations can vary significantly among trenches and within the same trench in different periods (from ca. 2.0 to ca. $6.9 \mathrm{mll}^{-1}$ ), but are generally sufficient for supporting the respiration of an abundant and diversified benthic fauna (Belyaev, 1989). Deepsea trenches are giant sedimentation tanks that accumulate both particles from the water surface layers and those transported from the ocean bottom sections adjoining the trenches (Danovaro et al., 2003). Sediments of the trench floor located in the ocean productive regions are characterized by considerably higher organic matter content than sediments in adjacent abyssal plains. The Atacama Trench, the deepest ecosystem of the southern Pacific Ocean (ca. $8000 \mathrm{~m}$ depth), for instance, has extremely large amounts of sediment organic matter, phytopigments, proteins, carbohydrates and lipids (Danovaro et al., 2003). These values were coupled with high bacterial abundance, biomass and carbon production and extracellular enzymatic activities, with values one to two orders of magnitude higher than their average values at abyssal depths (Danovaro et al., 2003). These findings indicate that the Atacama trench behaves as a deep oceanic trap for organic material where, despite the extreme conditions, benthic microbial processes are accelerated as a result of organic enrichment.

\subsection{The pelagic system}

The major structuring variable in the water column is depth and its covariance with temperature and the penetration of sunlight (Angel, 2003; Bucklin et al., 2010). This structuring results in a layering of the ecosystems of the open-ocean pelagic (Robison, 2004). The pelagic deep ocean is generally considered to mean deeper than the penetration of sunlight sufficient to support photosynthesis. That, of course, varies geographically but is generally found around $200 \mathrm{~m}$ depth and coincides with the maximum depth of seasonal variability in temperature, the seasonal thermocline (Herring, 2002). Closest to this surface zone (or epipelagic), the deep layer where sunlight penetrates during the day but with insufficient intensity to support primary production is called the mesopelagic (Robinson et al., 2010) or, in popular literature, the "twilight zone". At $200-1000 \mathrm{~m}$ depth, this zone is about four times as thick as the epipelagic and is coincident with the vertical temperature gradient known as the permanent thermocline. In some geographic areas, microbial degradation of organic matter sinking from the surface zone results in low oxygen concentrations in the mesopelagic, forming pelagic OMZs (see Sect. 3.3). Below the depth to which sunlight can penetrate - about $1000 \mathrm{~m}$ at noon on a sunny day in clear water (Angel, 2003) - we find the largest layer of the deep pelagic and by far the largest ecosystem on our planet, the bathypelagic (Robison, 2008). The bathypelagic comprises almost $75 \%$ of the volume of the ocean and is generally remote from the influence of the bottom and its ecological communities. Once within the benthic boundary layer, where both physical and biological interactions 
with the bottom occur, the nature of the pelagic ecosystem is altered by these interactions and is termed benthopelagic (or abyssopelagic over abyssal areas). Animals of the benthopelagic include some that spend their lives drifting and swimming above the bottom and others that live on the bottom but occasionally swim up into the water and then return to the bottom (demersal animals) (Marshall, 1979). The transitions between the various vertical layers are gradients, not fixed surfaces, so ecological distinctions among the zones are somewhat "fuzzy" across the transitions.

The Global Thermohaline Conveyor Belt drives the ocean circulation system, forced primarily by the cooling of surface ocean waters at high latitudes (e.g. in the NorwegianGreenland Sea and around the Antarctic Continent). The cooler water sinks and flows toward lower latitudes to establish the presently prevailing current deep-ocean circulation patterns (Gage and Tyler, 1991). In the North Atlantic, this leads to the formation of North Atlantic Deep Water (NADW), which flows south through the Atlantic Ocean before being deflected East around South Africa and then north into the Indian and Pacific Oceans (Gage and Tyler, 1991). Similarly, Antarctic Bottom Water flows north from the Antarctic into the Atlantic Ocean, as well as into the Indian and Pacific Oceans. A significant proportion of this deep water is also channelled into the Circumpolar Deep Water (Clarke, 2003) that can serve to help isolate deep-water communities around the Antarctic from those in the other major oceans. In the Arctic, by contrast, the topography of the seafloor restricts significantly deep-water circulation and the lack of, rather than abundance of lateral deep-water flow can also lead to restrictions on gene-flow in the deep ocean (Clarke, 2003). This deep-ocean circulation plays a major role in the distribution of pelagic species and gene flow both for pelagic and benthic species that disperse and colonise new habitat through pelagic larvae.

\section{Productivity issues}

\subsection{A food-poor environment with scattered oases of life}

A unique characteristic of deep-sea ecosystems is the lack of photosynthetically-usable sunlight below $\sim 200 \mathrm{~m}$ (Thistle, 2003). In the absence of photosynthesis, most of the deep sea is heterotrophic, where food must sink or be advected from the euphotic zone. The total net primary production on Earth exceeds 100 billion tons of carbon per year, with about half occurring in the oceans by phytoplankton (Behrenfeld et al., 2006). This plays a major role in carbon re-cycling through the fixation of carbon from inorganic into organic matter and transferring it from the sun-lit layers to the deep sea by grazing, sinking and active transport by vertically migrating pelagic animals (Robinson et al., 2010). The oceans' surface primary productivity varies both regionally (Yool et al., 2007) and seasonally (Lampitt et al., 1985), depending on the physical conditions of each region throughout the annual cycle. These variations result in spatio-temporal differences of organic matter input to the seafloor (Billett et al., 1983). It has been calculated that only 0.5 to $2 \%$ of the net primary production in the euphotic zone reaches the deep seafloor below $2000 \mathrm{~m}$ (Buesseler et al., 2007). Deep-sea benthic communities are thus among the most food-limited on the globe (Smith et al., 2008), yielding low faunal biomass and productivity (Rex et al., 2006; Rowe et al., 2008). However, the deep-sea is not uniformly food poor - embedded within this oligotrophic matrix are extraordinary oases of high productivity. Such habitats occur when organic material from the euphotic zone becomes concentrated by canyons, whale falls, wood falls, and OMZs (Levin, 2003; Smith and Baco, 2003; Smith, 2006; Vetter et al., 2010). Food-rich oases also occur where seafloor effluxes of chemical energy at hydrothermal vents and cold seeps support intense chemolithoautotrophic primary production. Even though these food-rich habitats are often small in area, extremely isolated and ephemeral at the seafloor (e.g., spanning 10s of meters, separated by $100 \mathrm{~s}$ of kilometres and lasting for years to decades in the case of vents and whale falls), they all support remarkable communities highly distinct from those of the background deep sea. Substantial adaptive radiations leading to extraordinary evolutionary novelty and contributing fundamentally to biodiversity (Van Dover, 2000; Smith and Baco, 2003; Smith, 2006; Fujiwara et al., 2007; Samedi et al., 2007; Lorion et al., 2009) have sustained many of these habitat types, including vents, seeps, whale falls and wood falls. In contrast, at shelf depths where in situ photosynthesis leads to much greater background levels of productivity, some of these same habitat islands (e.g. vents, seeps, low-oxygen zones) may have yielded relatively few adaptive radiations and little evolutionary novelty (Levin, 2003; Tarasov et al., 2005; Smith, 2006). Thus, the extraordinary oligotrophic nature of the general deep sea has exerted remarkable selective pressure on eutrophic specialists, creating truly extraordinary adaptations, levels of community heterogeneity and patterns of biodiversity.

\subsection{Life driven by chemical energy}

The discovery of hydrothermal vents in 1977 (see Sect. 2.3) changed our understanding of primary production in the oceans (Baker et al., 2010a). The superheated hydrothermal fluid is charged with sulphide, hydrogen, methane, manganese and other metals and depleted of magnesium and oxygen. In investigations of how the exuberant populations thriving on vents were sustained, the presence of sulphide in the vent fluid and abundance of bacterial mats provided the first clues. At hydrothermal vents, micoorganisms play the role of primary producers, using reduced compounds (mainly $\mathrm{H}_{2} \mathrm{~S}$ and $\mathrm{CH}_{4}$ ) as sources of energy, and inorganic carbon to produce organic matter in a process known as chemosynthesis, fuelling faunal communities that are believed to be 


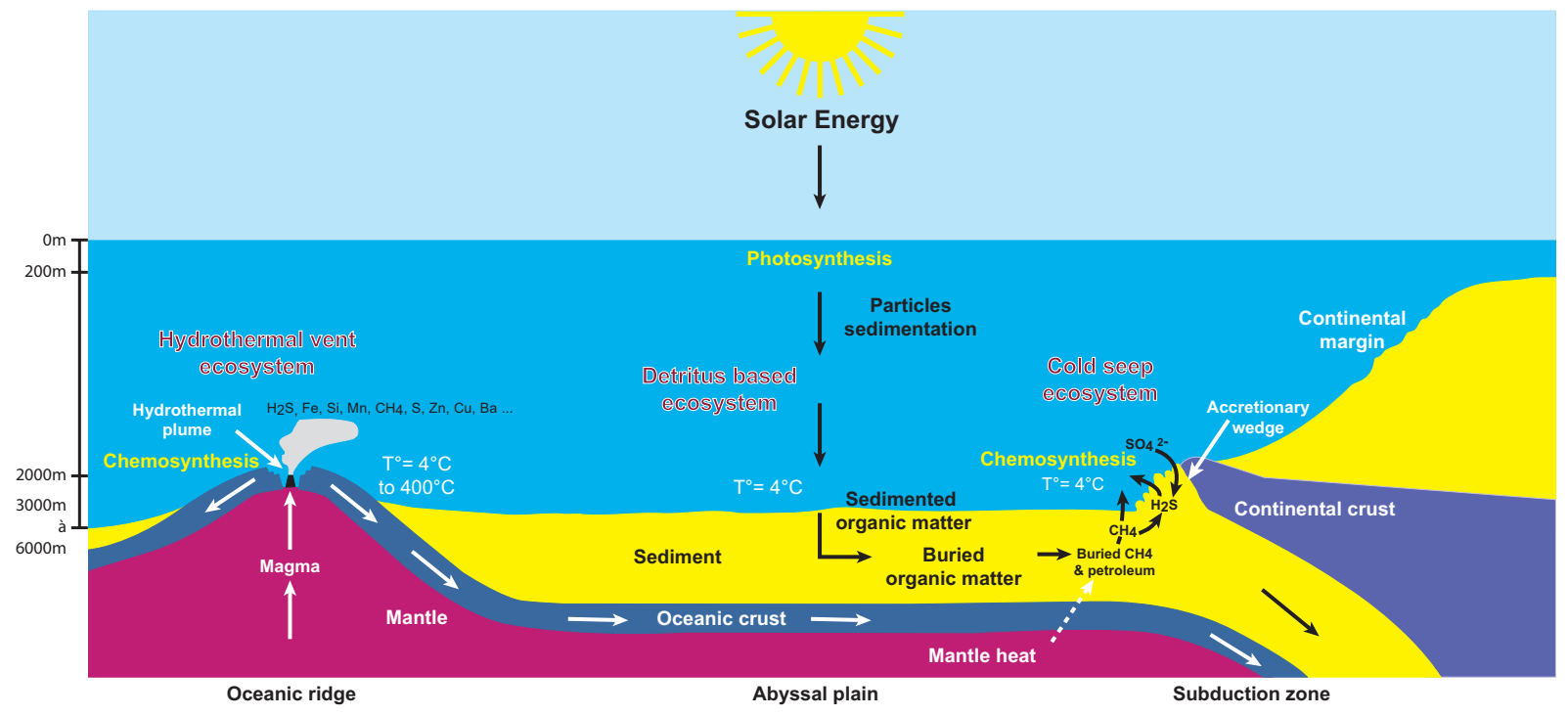

Fig. 3. Energy input in different deep-sea ecosystems. Heterotrophic communities are fuelled by primary production of phytoplankton in the surface layers of the ocean that use solar energy (photosynthesis) as the source of energy. Chemosynthetic communities are fuelled by primary production of microorganisms that use chemical energy from reduced chemical compounds (chemosynthesis) coming from the Earth's interior, or by large detrital parcels, such as whale falls and wood falls. Modified from Sibuet and Olu-Leroy (2002).

amongst the most productive on Earth (reviewed in Van Dover, 2000; Cavanaugh et al., 2006). In shallow-water habitats, organic matter in the sediment is oxidised by sulphatereducing bacteria that use seawater sulphate in anoxic conditions. This generates sulphide, which, in aerobic conditions, is oxidised by microorganisms producing organic matter. In this process, there is no gain of organic matter, since organic material must be oxidised to produce sulphide. In hydrothermal vents, sulphide originates geochemically in the ocean's crust through the interactions of seawater and hot rock, providing the necessary energy to generate organic matter from $\mathrm{CO}_{2}$ with a net gain of organic carbon (Jannasch and Mottl, 1985). The vent microorganisms play the same role as green plants and algae on land and in shallow waters: whereas plants and algae use solar energy (photosynthesis), vent bacteria use reduced chemicals as source of energy (chemosynthesis) (Fig. 3). However, vent ecosystems are not completely independent of sunlight. All animals and some microorganisms at vents need, for their metabolism, dissolved oxygen, which is produced during photosynthesis. This closely links the surface euphotic layers with the deepsea communities (Van Dover, 2000; Dubilier et al., 2008).

The reduced compounds in the vent fluid ensure a constant and abundant source of energy for microbial primary production and chemosynthetic bacteria are found both free living, forming bacterial mats, and in symbiosis with many of the macro- and megafauna (Dubilier et al., 2008). The first symbiotic relationship to be analysed from vents was that of the giant tubeworm Riftia pachyptila and its endosymbionts. R. pachyptila has very specific adaptations, lacking a mouth and digestive tract. Instead, this species has an organ called the trophosome densely packed with endosymbiotic chemoautotrphic bacteria (reviewed in Cavanaugh et al., 2006). Before the discovery of $R$. pachytila and their endosymbionts, the only trophic symbiotic relationships known were shallow water phototrophic symbiosis such as the ones found in corals, and heterotrophic symbiosis such as the ones that take place in the rumen of ruminant animals. It was thus with the discovery of vents that the first chemoautotrophic symbiotic relationship was described (Dubilier et al., 2008). It is only in deep-water reducing ecosystems, such as vents and seeps, where communities are dominated by fauna with chemosynthetic symbiosis. In shallow waters, where primary productivity is based on photosynthesis and the fauna can gain enough energy from this source, chemosynthesis is never dominant (Dubilier et al., 2008). This is the case even in shallow water vents and seeps, where typical vent fauna is rare (Tarasov et al., 2005), with one known exception in a vent community at $100 \mathrm{~m}$ depth off the coast of Japan, where the tubeworm Lamellibrachia satsuma dominates (Hashimoto et al., 1993). It has been suggested that the distinction between shallow- and deep-water chemosynthetic communities is not clear cut, but rather an ecological continuum where heterotrophy dominates in shallow waters and fauna relying on chemoautotrophic microorganisms dominate in deep benthic systems (Little et al., 2002).

The constant availability of energy and symbiosis between chemoautotrophic microorganisms and fauna are responsible for the success of vent communities and the high biomass observed. The luxuriant abundance of exotic life-forms found at vents contrast with the apparently bare surrounding deepsea floor, bringing to mind the analogy with oases on land 
(Carney, 1994). Since the discovery of vents in the late 1970s, over 600 species have been described from these habitats (Desbruyères et al., 2006; Baker et al., 2010b), 70\% of species being endemic to vents. In spite of this, diversity at hydrothermal vents is low when compared to the surrounding deep-sea benthos. Although the bathyal and abyssal heterotrophic deep seafloor was believed to be a monotonous and poor ecosystem, we know now that it supports biodiversities among the highest on Earth (see Sect. 5), mainly of small benthic macro- and meiofauna (Hessler and Sanders, 1967; Grassle and Macioleck, 1992; Snelgrove and Smith, 2002). Whereas in soft-sediment deep-sea habitats the abundance of species is evenly distributed with the most abundant species not exceeding 20\% of the total (Grassle et al., 1985), at vents, the communities are dominated by a few species ( 1 or 2 species can account for up to $70-90 \%$ of the total abundance) highly adapted to the environment (Van Dover, 2000). Vents are dynamic systems where catastrophic eruptions can wipe out whole communities in very short periods of time. The environmental conditions are also extreme to most fauna, with steep temperature gradients and high concentrations of hydrogen sulphide, which fuels chemosynthesis but is toxic to aerobic metazoans. These physicochemical factors select for a small number of taxa, which have developed very specific physiological adaptations (Tunnicliffe et al., 2003).

Following the discovery of hydrothermal vents, other reducing ecosystems where chemoautotrophic microorganisms are at the base of food webs supporting dense communities of highly adapted organisms have been found at bathyal and abyssal depths (reviewed in Tunnicliffe et al., 2003). Coldseep communities were first discovered in the Gulf of Mexico in 1984 (Paull et al., 1984). Cold seeps are found both on passive and active margins and are characterised by seepage through the sediment of cold fluid with high concentrations of methane. The methane can have a biological origin from the anoxic microbial decomposition of organic matter, or a thermogenic origin from fast transformation of organic matter by high temperatures (Sibuet and Olu, 1998; Tunnicliffe et al., 2003; Levin, 2005). Cold seeps can also have high concentrations of sulphides in the sediment, produced by microbial sulphate reduction. As in vents, free-living and symbiotic chemoautotrophic microorganisms use the reduced compounds in the habitat to produce organic matter, supporting dense communities of fauna. Megafaunal biomass is significantly higher than that of the surrounding sediments, with a fauna similar to those from hydrothermal vents, especially at high taxonomic levels (i.e. genus and family) (Tunnicliffe et al., 1996; Sibuet and Olu, 1998). The major faunal groups found in cold seeps are bivalves (mytilids, vesicomyids, lucinids and thyasirids) and siboglinid tubeworms, decapod crustaceans (shrimp and crabs), gastropods and cladorhizid sponges (reviewed in Levin, 2005).

In the specific case of asphalt eruption habitats (e.g. Chapopote; see Sect. 2.6), siboglinid tubeworms root their posterior end below individual flows and occur at sites with high concentration of volatile hydrocarbons. There, they probably take up hydrogen sulphide resulting from the microbial-mediated hydrocarbon degradation at the base of the asphalt deposit that is in contact with sediments (Freytag et al., 2001). Heavily altered asphalts lack chemosynthesisbased communities, with only a few exceptions (i.e. vestimentiferans tubeworm and mytilid mussels) that are found in the locations where active gas venting has been documented (MacDonald et al., 2004). Mytilids are present in close proximity to the seep site in the absence of asphalt. Vesicomyid clams and bacterial mats are found in sediments close to asphalt deposits, asphalt fissures and at visible cracks in the asphalt surface. Bacterial mats cover the areas of freshest flow and occur as small patches in cavities on the asphalt. However, the dependence of the bacteria on the asphalts is still unclear. Heterotrophic fauna are also abundant around Chapopote (MacDonald et al., 2004). Alvinocarid shrimps, the holothurian Chiridota heheva and the galatheid Munidopsis occur within the vestimentiferan tube aggregations and mussel beds. Small gastropods occur in large densities along the vertical walls of asphalt at the rising gas hydrate site. Macrofaunal and meiofaunal samples were obtained from the superficial soft sediment close to the asphalt structures, showing a large abundance of harpacticoid copepods and tanaidaceans.

Chemosynthetically-driven communities can also derive from sunlight-related systems. In 1989, a chance discovery of a skeleton of a whale during a dive of the submersible Alvin led to new findings related to chemosyntheticallydriven communities (Smith et al., 1989). Whale falls have been described to pass through at least three successional stages (Smith and Baco, 2003). During the scavenger stage, large animals such as sharks, fish and crabs are attracted by the sudden input of organic matter and the flesh of the whale is eaten. An opportunistic stage follows, where small opportunistic fauna such as polychaetes and small crustaceans clean up the bones and colonise the enriched sediments surrounding the whale skeleton. The third phase is the sulphophilic stage, during which the oil-rich whale skeleton (up to $70 \%$ of lipid by weight) is decomposed by anaerobic bacteria to produce reduced chemicals (e.g. sulphide), which are in turn used by chemosynthetic bacteria producing organic matter. More than 50 new species have been reported from whale falls in the North Pacific alone, and fossil communities from reducing environments occur on fossil whale falls from 10-20 million years ago (Amano et al., 2007). Because of the specific characteristics of reducing deep-sea ecosystems (vents, seeps and whale falls), the fauna described from whale falls also have many phylogenetic similarities at the genus and family level with vent and seep faunas (Smith and Baco, 2003; Tunnicliffe et al., 2003). 


\subsection{Life under hypoxic conditions}

Mid-water oxygen minimum zones (OMZ, with $<0.5 \mathrm{ml}^{-1}$ or $22 \mu \mathrm{MO}_{2}$ ) occur naturally in the oceans under areas of intensive upwelling and surface productivity, particularly where circulation is sluggish and source waters are relatively old. In these areas of intense upwelling, phytoplankton productivity is high and carbon availability exceeds metazoan capability to consume it. The excess carbon sinks to a pycnocline or the sediment, where it is decomposed by heterotrophic microbial activity. The increased microbial respiration forms severely oxygen-depleted zones that vary in thickness from 200 to $1000 \mathrm{~m}$ (Wyrtki, 1962; Levin, 2003; Levin et al., 2009). These occur mainly along the eastern Pacific Ocean, northern Indian Ocean and western Africa and, where they intercept the continental margin, can create seafloor OMZs covering over 1.1 million $\mathrm{km}^{2}$ (Helly and Levin, 2004). These zones of permanent hypoxia may last for thousands of years (Reichart et al., 1998) and are major sites of carbon burial on continental margins. Studies initiated in the early 1960s showed that OMZs support extensive autotrophic bacterial mats despite intense oxygen depletion (Gallardo, 1963, 1977; Fossing et al., 1995; Gallardo and Espinoza, 2007). Protozoan and metazoan communities also thrive in these ecosystems but with greatly reduced diversity and specific adaptations to hypoxia. Metazoan adaptations include larger respiratory surfaces, specific blood pigments such as haemoglobin, higher number of pyruvate oxidoreducatases, small thin bodies and support structures for living in soupy sediments. In some cases, organisms may also house sulphide-oxidising symbionts and have chemosyntheticallybased trophic adaptations similar to those found in vents and seeps (reviewed in Levin, 2003). Mats of sulphide-oxidising bacteria (Thioploca, Beggiatoa, Thiomargarita) are often found in the lowest-oxygen core regions of OMZs. Dense aggregations of protists and metazoan meiofauna including calcareous foraminifera also abound there. In contrast, macro and megafauna densities are higher at the edges of the OMZs, with low diversity, low species richness and high dominance (Sanders, 1969; Levin, 2003, 2009; Gooday et al., 2009).

\subsection{Seamounts: topographic enhanced productivity}

Seamounts provide dramatic contrast to the surrounding flat abyssal plains and edges of continental margins. Most have a complex topography and are colonised by a range of mainly epifaunal, suspension-feeding organisms dominated by cnidarians (gorgonians, zoanthids, antipatharian corals, actinians, pennatulids and hydroids), with sponges, cirripeds, molluscs, crinoids and ascidians also prominent (Rogers, 1994; Consalvey et al., 2010). Other groups recorded include ophiuroids, asteroids and holothurians (Narayanaswamy et al., 2006; Roberts et al., 2008).

Seamounts in some areas act as biological hotspots in the oceans and often attract a high abundance and diversity of top-level predators (Worm et al., 2003; Dower and Brodeur, 2004). For increased productivity over seamounts to occur, nutrient-rich water must reside over the seamount for long enough to enhance phytoplankton growth and for this to be transferred to higher trophic levels. Whilst there is evidence of increased primary productivity over seamounts, data are sparse and difficult to relate to the increased populations of pelagic and benthic predators (Uchida and Tagami, 1984; Parin et al., 1997). Zooplankton trapped by currents over the summits of seamounts, suggest that this is an important mechanism of trophic focusing over many of these features (Genin, 2004). Whether this occurs or not depends on the depth of the seamount summit with respect to the depths over which the deep scattering layers (DSL) of plankton migrate, as well as on the intensity of horizontal currents that advect the DSL over the seamount at night. Studies of fish populations over seamounts have shown that the fish prey on the migrating zooplankton and may be concentrated around the margins of the summit in order to maximise chances of encountering the zooplankton (Rogers, 1994; Fock et al., 2002). These mechanisms may also be important in the nutrition of abundant benthic communities on seamounts. Other mechanisms of concentration of food may also operate around seamounts associated with eddies or up- or downwelling currents (Genin, 2004).

\subsection{Submarine canyons: essential habitats on continental margins}

Submarine canyons are major topographic structures that form deep incisions in the shelf and continental margins around the globe. Because of their rugged topography and difficult access, detailed multidisciplinary (geological, physical and biological) studies have developed only in the last two decades, in parallel with advances in marine technology such as swath bathymetry, remote sensing, long-term moorings and ROVs. Such studies have defined canyons as essential habitats for the local fauna (Sardà et al., 2009). Essential habitats are ecosystems used by the fauna for a critical stage of their life cycle, ecosystems with a particular combination of abiotic and biological characteristics, with a highly complex structure and/or those that favour critical aspects of life such as reproduction, feeding and refuge. Canyons are complex habitats with specific hydrographic, sedimentological and geochemical characteristics (Durieu de Madron et al., 1996; Turchetto et al., 2007; Flexas et al., 2008) that influence faunal community structure, diversity and abundance (Schlacher et al., 2010). Important effects of submarine canyons on the environment include the modification of local current regimes and their role as major conduits for transport of particulated organic carbon (Heussner et al., 1996; Puig et al., 2003) and macrophytes (Vetter and Dayton, 1999) from the coast or shelf to bathyal and abyssal depths. Canyons are also major deposition centres of sediment in margins (Oliveria et al., 2007) and can play an important role in intensifying 
episodic events such as dense water cascading (Canals et al., 2006), with important ecological implications on the benthopelagic populations (Company et al., 2008).

Furthermore, canyons are heterogeneous habitats. The canyon head and walls can present rocky outcrops suitable for sessile filter feeders such as cnidarians and sponges, while the axis of the canyon can accumulate soft sediment and have a fauna dominated by deposit feeders, scavengers and predators such as echinoderms, crustaceans and fish. Because of their higher habitat heterogeneity and accumulation of organic matter, canyons are predicted to support a higher diversity and biomass than the adjacent slope. While this is true in some cases (Rowe et al., 1982; Sardà et al., 1994; Gage et al., 1995; Vetter and Dayton, 1999; Ramirez-Llodra et al., 2008, 2010), other studies have shown no significant differences in biomass and abundance of benthic fauna between the slope and canyon habitat (Houston and Haedrich, 1984) or lower biomass and abundance in the canyon (Maurer et al., 1994). The modified currents within the canyon can shape faunal distribution patterns by modulating disturbance intensity over the seafloor (Sardà et al., 1994a, b, 2009). It has also been shown that certain pelagic species are retained within the canyon, resulting in increased abundance and diversity (Gili et al., 1999; Albaina and Irigoien, 2007; Robison et al., 2010). Finally, the hydrography and increased food availability of canyons provide favourable areas for recruitment and maintenance of certain megafaunal species, including some of commercial value (Sardà et al., 1994b, 1997; Stefanescu et al., 1994; Tyler and Ramirez-Llodra, 2002).

\subsection{Cold-water corals: reefs in the absence of sunlight}

Cold-water corals are important habitats for many species in the deep sea. Such habitats can be massive, forming reefs where the seabed underneath the habitat-forming organism is made up of an accumulation of skeletons and sediment, or can be characterised as "gardens" where the structure is more open without an accumulation of skeletons. Cold-water corals are found in waters with temperatures between 4 and $13^{\circ} \mathrm{C}$ (Freiwald, 2002) and depths varying form 50 down to $6000 \mathrm{~m}$ (Roberts et al., 2006). In shallow-water reefs, a robust 3-D structure is formed by a great diversity of calcifying organisms performing the functions of framers, cementers and infillers. On the contrary, cold-water coral reefs are formed by a much smaller number of organisms and in a much slower process, but have the ability to establish stabile ecosystems for a longlasting period (2.5 Ma) (Kano et al., 2007). Cold-water corals comprise a heterogeneous group of cnidarians with representatives from hydrozoans (Stylasteridae), octocorals (Alcyonaria, Gorgonacea, and Pennatulacea) and hexacorals (Scleractinia and Antipatharia). The scleractinian Lophelia pertusa, the commonest reefforming scleractinian occurring mainly in the Atlantic and at a minor extent in the Pacific (Roberts et al., 2009), has been the subject of several recent studies. L. pertusa has a wide geographical distribution, ranging from $55^{\circ} \mathrm{S}$ to $71^{\circ} \mathrm{N}$ (Dons, 1944; Zibrowius, 1980; Cairns, 1982).

Knowledge about the distribution and structure of these habitats remained limited until in situ studies and mapping of large areas became possible by using ROVs and multibeam echosounder in the early 1990s (Mortensen et al., 1995). Because of their role as hot spots for biodiversity and sensitivity to external pressures such as bottom fisheries, research on cold-water corals has increased lately. Cold-water corals are found in all world oceans and the Mediterranean Sea, from shallow waters to ca. $4000 \mathrm{~m}$ depth in the Atlantic Ocean (Grasshoff, 1982) and ca. 6300 in the Pacific (Keller, 1976). However, most species occur at intermediated water depths between 200 and $1000 \mathrm{~m}$ (Mortensen et al., 2006 and references therein). Cold-water coral build-ups have been found along the northwest European continental margin in the fjords and offshore Norway as open reef structures about 8000 years old (e.g. Fossa et al., 2005), around the British Isles (Wilson, 1979; Roberts et al., 2009), the Faeroe Islands (Frederiksen et al., 1992; Jensen and Frederiksen, 1992), as very large build-ups along the Rockall Bank (Scoffin et al., 1980), the Rockall Trough (e.g. Mienis et al., 2007; Dorschel et al., 2009), the Porcupine Bank (Scoffin and Bowes, 1988), Porcupine Seabight (e.g. De Mol et al., 2002), and as gardens in the Gollum channels (Tudhope and Scoffin, 1995), Gulf of Biscay (e.g. Reveillaud et al., 2008) and in the Mediterranean Sea (Zibrowius, 1980; Taviani et al., 2005). Besides the NE Atlantic, corals and coral build-ups have also been reported along the west African margin (Le Guilloux et al., 2009; Colman et al., 2005), in the northwest Atlantic (Messing et al., 2008), Blake Plateau (Reed, 1992), near the Bahamas (Messing et al., 1990; Neumann et al., 1977; Paull et al., 2000), in the Gulf of Mexico (Cordes et al., 2008; Davies et al., 2010), Canada (Wareham et al., 2007), Alaska (Stone, 2006) and from a few scattered records in the Pacific (Squires, 1965; Etnoyer and Morgan, 2005) and Indian Ocean (Rogers, 1999).

Even though there are many similarities between hermatypic reefs and ahermatypic reefs, the trophic structure of the communities of each is fundamentally different. Coldwater corals are unique in that they are azooxanthellate, lacking the symbiotic algae of shallow-water corals. The internal cycling of nutrients and the significance of phototrophy in shallow reefs (Froelich, 1983) is a great contrast to the food supply for deep dark reefs, which consists of advected particulate organic matter (Duineveld et al., 2004) and small prey such as chaetognaths, crustaceans and krill (Roberts et al., 2009).

\subsection{Strong oligotrophy under ice: the Arctic Ocean}

Since food availability is a major structuring factor for deepsea communities (Gage, 2003), most taxa are sensitive to changes in the availability of organic matter on the deep seafloor (Smith et al., 2008). Oligotrophic conditions negatively affect macro- and meiofauna standing stock (Vincx et 
al., 1994; Cosson et al., 1997). Therefore, perennial or longterm ice cover in polar sea regions, which impedes or delays phytoplankton production, strongly affects the entire underlying pelagic (Arrigo et al., 2002) and benthic ecosystem (Clough et al., 1997; Kröncke et al., 2000; Vanreusel et al., 2000). However, the ocean floor below extensive ice cover is not a desert devoid of life. Antarctic sub-ice benthic communities can be rich and abundant, as the seafloor beneath large ice shelves may be accessible for colonization through the open water (Post et al., 2007; Riddle et al., 2007; Raes et al., 2010). The idea that the Arctic Ocean is a biological desert has been challenged also by recent observations. It is indeed generally accepted that fluxes of organic material from the surface to the deep-sea floor are mainly related to primary productivity in the overlying water column and to water depth (Asper et al., 1992; Relexans et al., 1996). However, it is evident that large regional differences in primary production occur in northern latitude oceans, determined by density of ice cover, water column stratification and the availability of dissolved nutrients and light (AMAP, 1998). Marginal ice zones are even key areas of elevated productivity that exceeds the production of more southern latitudes (Smith and Sakshaug, 1990). Ice margins shift both seasonally and with climate change and are characterized by high biological productivity within an oligotrophic Arctic Ocean (Sakshaug and Skjoldal, 1989; Sakshaug, 1997). According to a comparative study among benthic size classes from the central Arctic (Kröncke et al., 2000), bacterial and all faunal abundances as well as bacterial and macrofaunal biomass decreased significantly with increasing latitude. These authors suggest that the significant relationships between the bacterial and faunal size-classes points to a distinct food chain, typical of oligotrophic systems. The smallest compartments - bacteria, meiofauna and foraminifera - were more abundant than the macrofauna in the central Arctic Ocean. While macrofauna biomass dominated the biomass on the Barent Sea shelf and slope and on the Lomonosov Ridge, the bacterial biomass was equally or even more important on the Gakkel Ridge and in the deep basins. This study revealed that the Eurasian Basin is one of the most oligotrophic regions in the world's oceans. Although primary production is low, recent foraminiferal investigations have revealed that benthic communities in the central Arctic Ocean are driven by the sedimentation of fresh organic material. Lateral transport of organic matter from the Siberian shelf may provide additional food.

The various benthic compartments compete either for fresh organic matter or for refractory material that is made available to higher levels of the food chain by bacterial activity (Kröncke et al., 2000). Not only benthic densities and biomass, but also diversity, are in general low in the central Arctic (Pfannkuche and Thiel, 1987; Vanaverbeke et al., 1997a; Schewe and Soltwedel, 1999; Soltwedel et al., 2000; Vanreusel et al., 2000; Schewe, 2001; Renaud et al., 2006). Renaud et al. (2006) observed that there was a trend toward reduced taxonomic richness with increasing latitude in the central Arctic for both macrofauna and nematodes (the major meiofauna taxon). Diversity of nematode genera was also significantly higher on the Arctic Ice Margin near Svalbard (Hoste et al., 2007) and the Laptev Sea (Vanaverbeke et al., 1997a), compared to the Central Basins at similar water depths (Vanreusel et al., 2000; Renaud et al., 2006). Since fauna within the deep benthic Arctic Ocean appear to represent a single species pool, Renaud et al. (2006) suggest that both local $(\alpha-)$ and regional ( $\beta$-) diversity may be determined by ecological processes in the Arctic, and that they are mainly driven by historical or evolutionary processes. Studies on bentho-pelagic coupling, which are known to play a significant role in determining benthic community structure and function at high latitudes, are crucial in future investigations of Arctic deep-sea biodiversity.

\section{Unique traits of deep-sea communities}

\subsection{A distinctive benthic deep-sea fauna}

The taxonomic composition, size, diversity patterns and functioning of deep-sea communities are a product of evolutionary legacy and ecological processes. Of the approximately one million animal species described on the planet, between 95 and $98 \%$ are invertebrates belonging to 30 phyla, although this number is ever increasing. Of these 30 phyla, all but one - the Onychophora - occur in the ocean, and there is Cambrian fossil evidence that the Onychophora may have once been marine. Echinoderms are found only in marine systems and many of the other phyla occur only in water. None of these phyla are exclusively found in the deep sea, but at a lower taxonomic level several groups of animals make the deep sea special (Fig. 4). Among these, the "living fossils" Monoplacophora are exclusively deep-living $(>2000 \mathrm{~m})$. Many others are much better represented or are more speciose in the deep sea than in shallow waters such as the Tanaidomorpha, Asellota, Pycnogonida, Galatheoidea, Priapulida, Sipuncula, Echiura and Aplacophora. The tanaid suborder Tanaidomorpha includes a high fraction of the fauna in disturbed settings such as the HEBBLE site with benthic storms (Thistle et al., 1985) and in hydrothermal or seep sediments (Levin et al., 2010b). The isopod suborder Asellota is one group that have radiated to form an amazing array of unorthodox body morphologies in the deep sea (Fig. 4). Isopod diversity is remarkably high in oligotrophic settings, for example 130 species have been identified from 493 individuals in the equatorial eastern Pacific manganese nodule province (Wilson and Hessler, 1987). The Pycnogonida are chelicerate sea spiders that are especially common in cold, deep-sea and polar waters. The largest pycnogonid species are carnivores and scavengers that can attain sizes up to $90 \mathrm{~cm}$ by having extremely long legs, and are unusual in exhibiting male parental care. The Galatheoidea, or squat 


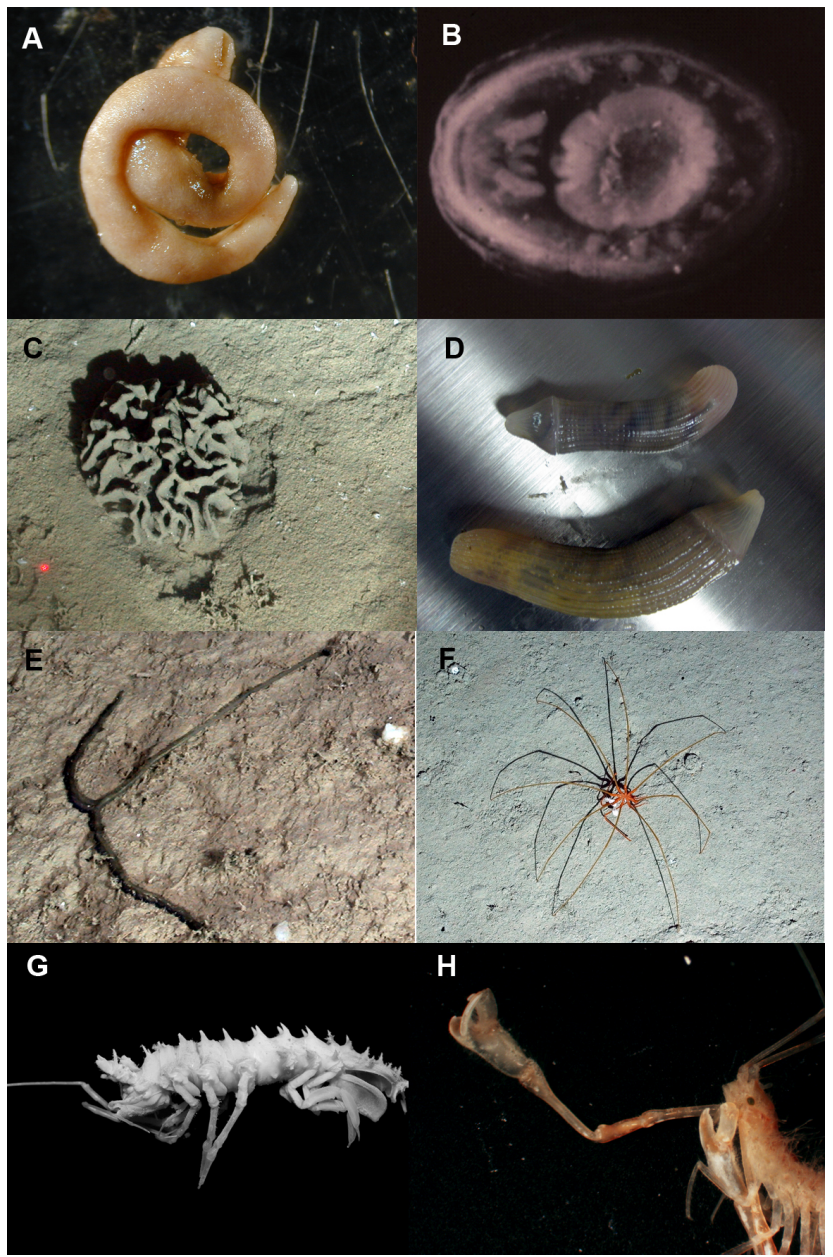

Fig. 4. Examples of deep-sea fauna. (A) aplacophoran ${ }^{(C)}$ Mike Vecchione, NMFS. (B) monoplacophoran (C) Lisa Levin, SIO. (C) Xenophyophore $\left.{ }^{(}\right)$Paul Tyler, NOC/NERC. (D) Sipunculid from bathyal depths in the NW Mediterranean ${ }^{(C)}$ Ariadna Mechó, ICM-CSIC. (E) Echiuran ${ }^{(C)}$ Paul Tyler, NOCS. (F) Pycnogonid (C) Paul Tyler, NOCS. (G) Sursumura from the Lazarev Sea deep sea (Southern Ocean) $\left.{ }^{(}\right)$Torben Riehl. (H) Male of the family Munnidae (Isopoda) from the SO deep sea (C) Wiebke Brökeland.

lobsters, are numerous and highly visible crustaceans on seamounts, continental margins, many shelf environments, coral reefs at all depths and at hydrothermal vents (Baba et al., 2008). Among the 870 known species of marine squat lobsters, about $85 \%$ are found in deep-sea benthic habitats (Baba et al., 2008). One of the species that has received most attention lately is Kiwa hirsuta, commonly known as the Yeti Crab, discovered on the Easter Island Microplate hydrothermal vents in 2005 and for which a new family (Kiwaidae) was erected (McPherson et al., 2005). The Priapulida, with 16 known species, are small and relatively rare in modern shallow waters, but are abundant historically (e.g. in the Burgess Shale, Ottoia) and in some of the less habitable zones of the deep ocean such as the OMZ (Levin et al., 2006). The vermiform phyla Sipuncula and Echiura are now recognized, through molecular analyses, to belong within the Annelida (Struck et al., 2007). Both of these groups have very large species that dwell within, burrow and bioturbate deep-sea sediments. They form highly visible structures (Lebensspuren) on the sea floor and can play key roles in subducting phytodetritus, burying carbon and in supporting other deep-dwelling infauna. Other sipunculids take on a characteristically endobiotic lifestyle, also found in shallow waters, living in the tubes, skeletons and tests of other organisms. Aplacophora is a class of mostly small, vermiform, shell-less molluscs, covered with spines that occur throughout the oceans but are particularly speciose in deepsea settings. Echinoderms, cnidarians and sponges are similarly conspicuous and form a significant fraction of the animal biomass on sedimented seafloor settings at depths below $1000 \mathrm{~m}$.

The reducing ecosystems on the deep seafloor also support taxa that are exclusively deep, such as siboglinid polychaetes (frenulate and vestimentiferan), bathymodiolid mussels and vesycomid bivalves. These have evolved a permanent relationship with sulphide- and/or methane oxidizing bacteria, termed endosymbiotic chemoautotrophs (see Sect. 3.2), which supply them with food and allow them to attain large sizes and high biomasses.

\subsection{Deep-sea benthos: a refuge for relict fauna?}

The deep seafloor, after initially having been considered azoic, was thought to be a refuge for a relict fauna. Emblematic "living fossils" that support this idea include, in order of discovery, the stalked crinoids, the monoplacophorans and the glypheids. The Crinoidea, a class of echinoderms, have an important place in the history of deep-sea biology. In 1864, G. O. Sars collected specimens at $550 \mathrm{~m}$ depth in Lofoten that his father, Michael Sars, described as a new species of stalked crinoid: Rhizocrinus lofotensis Sars, 1868. Emphasising the similarities of this new species with fossil records dating back from the Mesozoic (250 Ma), Sars suggested that the deep-sea floor was a refuge for living fossils. The so-called Sars's paradigm encouraged another student of crinoids, Charles Wyville Thomson, to instigate several cruises that culminated with the HMS Challenger expedition around the world. Today, stalked crinoids are known to be widespread on hard substrata in the deep sea. The Monoplacophora, a class of molluscs, were known only from fossil records dating back to the early Cambrian (540 Ma). In 1952, the first modern representative was collected from $3590 \mathrm{~m}$ off Costa Rica (Lemche, 1957). Since that time, a further 31 species have been found, of which 13 live below $2000 \mathrm{~m}$ water depth, with some occurring deeper than $6000 \mathrm{~m}$ (Schwabe, 2008). The Glypheidae, a family of decapods, most probably appeared in the Permian-Triassic (250 Ma), prospered in the Jurassic (200 Ma) and declined in 
abundance from the Cretaceous to the Eocene (Forest, 2006). A single living specimen however, was caught in 1908 in the Philippines at $200 \mathrm{~m}$ depth during an expedition of the Albatross. This strange decapod remained undescribed in the collections of the Smithsonian Institution for almost 70 years, until Jacques Forest and Michèle de Saint Laurent noted its similarity with supposedly extinct glypheids and described it as Neoglyphea inopinata (Forest and Sait Laurent, 1975). In the following years, three cruises were organised to collect intact males and females of the species and this gave rise to the MUSORSTOM programme, an exploration of the tropical deep-sea benthos that now has more than 50 cruises to the Western Pacific.

The concept of "living-fossil" species has also been extended to "living-fossil" communities. Hydrothermal-vent and cold-seep fossils are known from the Silurian to the Devonian (440-360 Ma). Putative tubeworms in particular were found in both vent and seep Palaeozoic communities, although their affinity with vestimentiferans is controversial (Little, 2003; Kiel and Dando, 2009). Mollusc genera at seeps are on average older than the marine molluscs in general, though not older than other non-seep deepsea genera (Kiel and Little, 2006). Non-symbiotic species endemic to seeps include sessile barnacles, gastropods and aplacophorans that are derivatives of primitive forms (Tunnicliffe, 1992). Recently, an association between the sessile crinoid Cyathidium foresti and a new species of deep-sea oyster, Neopycnodonte zibrowii, has been described from the slope of the Azores Archipelago, which resembles a fossil palaeo-community more than 60 million years in age (Wisshak et al., 2009). Monoplacophorans were found also on hydrothermal vents in the geological past and have only been replaced by large bivalves during the Tertiary.

The hypothesis that the deep seafloor offers a refuge for a relict fauna is also implicit in the model of onshore-offshore change in faunal diversity, suggesting that higher taxa originated in a shallow-water environment forced by high selective pressure. These species later invaded and eventually found refuge in deep-water environments against competition, predation and extinction (Sepkoski, 1991). This hypothesis, however, has also been seriously questioned since the deep-sea floor is not exempt from large-scale disturbances. The deep-sea benthos survived the Cretaceous-Palaeogene extinction event, but it may have suffered previous massive extinction events in relation with global anoxia or dysoxia until the late Cretaceous (100 Ma) (Jacobs and Lindberg, 1998). Later, a Paleocene-Eocene thermal maximum, 55 Million years ago, led to a $50 \%$ reduction in the richness of deep-sea benthic foraminifera (Thomas and Shackelton, 1996). Since then, three gradual turnovers in foraminiferan composition have occurred, which coincided with global cooling of the ocean (Thomas, 2007). It is thought that the modern foraminiferan fauna became established during the middle Miocene (12Ma). Some groups such as the stilostomellids, however, became extinct no later than the middle Pleistocene (1 Ma), during a period of intense glaciations of the Northern Hemisphere.

The search for living fossils has given rise to some of the most famous explorations for deep-sea fauna, but finally provided only a few examples to support Sars's paradigm. Advances in paleoceanography, paleobiology and phylogeography showed that the benthic deep-sea fauna suffered catastrophic events, massive extinctions as well as radiations, although it is still unclear whether these events were global or had disjunct distributions. Deep-sea and shallow water enthic faunas clearly differ in their taxonomic composition and functioning, but this probably merely reflects adaptations to deep-sea life rather than the preservation of an antique and uncompetitive fauna.

\subsection{Size matters}

Trends of both dwarfism and gigantism among faunal groups have been observed since early benthic deep-sea exploration (Moseley, 1880) and have long intrigued deep-sea ecologists. As body size may scale with biological diversity, understanding the adaptation of size to the deep-sea environment might offer clues in the interplay of evolutionary and ecological forces generating and maintaining biodiversity (Rex and Etter, 1998). Conflicting size-depth clines of dwarfism and gigantism in the deep-sea benthos, however, proved difficult to combine into one single theory (Gage and Tyler, 1991). In both cases, the main mechanism invoked is an adaptation to the decrease in food availability with depth. The energetic cost per unit mass is lower for big than for small invertebrates (Peters, 1983), thus favouring gigantism in the deep sea (Rex and Etter, 1998). However, as nutrient inputs decrease, so does abundance to a point where large organisms might not be able to maintain populations large enough to be reproductively viable. Dwarfism, though metabolically less efficient, would permit a larger number of conspecific individuals to co-exist, thus increasing the ability to acquire mates (Thiel, 1975, 1979). As a response to food limitation, the evolution of small body size in the deep sea might result from a trade-off between metabolic rate and reproductive efficiency. Alternatively, the optimality theory (Sebens, 1982, 1987), which balances energy cost and intake as a function of body mass, also predicts a trend of decreasing size with decreasing food supply in the deep sea (Rex and Etter, 1998). McClain et al. (2006) established a parallel between the evolution of body size in the deep sea and the island rule. The island rule describes the trend for large species on continents to be smaller on islands and inversely small species to get bigger, consequently reconciling conflicting patterns of gigantism and dwarfism. While several selective pressures have been proposed to explain insular patterns of body size, food limitation might be the only one that is shared with the deep sea (McClain, 2006). The need to maintain a viable population size would select for small body size among large 
species as suggested by Thiel $(1975,1979)$, while metabolic efficiency would favour gigantism among small species (McClain, 2006). In part, the geographic patterns of body size in the benthic deep sea have been obscured because variations in size have been studied at different taxonomic and functional levels, either within species, among species of similar taxa or between size classes.

The size-depth clines of individuals within species are best documented for gastropods (Rex and Etter, 1998; McClain et al., 2005, 2006). These organisms are particularly wellsuited for such studies because ontogenetic development is preserved in shell form and size can be compared at common growth stages (Etter, 1990). Deep-sea snails are either predators or deposit-feeders. Larvae can be planktotrophic or lecitotrophic with a wide range of dispersal capabilities. Most individual species, however, live in restricted depth bands and species turn-over is high along continental slopes. Independently of feeding modes or larval development, the general trend is for upper bathyal species to increase in size with depth, while lower bathyal species decrease in size towards the abyss. Among species, this results in a unimodal relationship between size of gastropods and depth, with a peak at ca. $3000 \mathrm{~m}$ depth (McClain et al., 2005). Along a bathymetric gradient, the size of upper bathyal species would have evolved mainly towards higher metabolic efficiency while, with constantly decreasing food supply, the size of lower bathyal species would be rather constrained by reproductive efficiency.

This rule may pertain for slightly mobile species, but not for swimming organisms, which are more likely to find mates. For example the size of lower bathyal and abyssal populations of the natatory isopod Eurycope iphthima increases with depth between 2500 and $4800 \mathrm{~m}$ (Wilson, 1983). Similarly, gigantism is widespread among the most mobile scavengers such as giant amphipods, isopods and large fishes. Large body size permits extended transits and extensive food storage between feeding bouts. This is a necessity in oligotrophic settings, where food parcels are few and far between, such as in the deep seafloor. Abyssal gigantism is also known for deposit-feeders, such as the elasipodid holothurians species Psychropotes longicauda that attains a length of $\sim 0.5 \mathrm{~m}$ in the abyss. Among carnivores, the pycnogonids provided the first example of abyssal gigantism (Moseley, 1880). Protozoans are also a good example. As found on terrestrial ecosystems, protozoans are numerically dominant and ecologically significant in the deep seafloor, but unlike on land, where protozoans are typically minute and inconspicuous, in the deep sea they can be large (Margulis, 1989). Foraminifera, protozoans with either calcareous or agglutinated tests (dwelling structures), occupy every environment in the deep ocean. Some specialized foraminifera called xenophyophores can form tests that are typically 5 to $>10 \mathrm{~cm}$ in size. Foraminifera are capable of significant carbon processing and may surpass metazoan activities in this regard, particularly under extreme conditions such as at very high pressure at the bottom of trenches (Todo, 2005) or under severe oxygen stress in OMZs (Woulds et al., 2007).

Opposing the theory that larger body size evolved in the deep sea as a response to low food supply are vents and seeps, where both bacteria and metazoan fauna can be exceptionally large. The deep seafloor hosts large numbers of bacteria (prokaryotes), which play fundamental roles in the remineralisation of organic matter and as food or settlement cues for animals. Normally small (microns in size) bacteria can become exceedingly large (cells reaching $1 \mathrm{~mm}$ in diameter and filaments several centimetres in length) in reducing environments such as methane seeps, hydrothermal vents, whale falls and OMZs, where they oxidize sulphide. The free-living forms of these bacteria (Beggiatoa, Thioploca, Thiomargarita, Thiothrix) can form massive mats that detoxify sulphide and provide a specialized habitat and food supply for a variety of tolerant invertebrates and even fishes (Gallardo et al., 1977, 2007; Jannasch and Wirsen, 1981). Other sulphide- and methane-oxidizing bacteria have developed symbiotic relationships with the megafauna, sometimes in specialized organs (see Sect. 3.2). These also play physiological and nutritional roles: animals with endosymbiotic bacteria often have reduced or have lost their feeding apparatus and digestive system. Autotrophic, symbiotic bacteria allow, amongst others, vesicomyid clams, gastropods, bathymodiolin mussels, siboglinid tubeworms, alvinocarid shrimps and even ciliates in the deep sea to harness the abundant supply of chemical energy emerging from the sea floor at vents, seeps and decaying whale and wood falls (Dubilier et al., 2008). Large size, high biomass and high density distinguish the fauna based on chemoautotrophy from their counterparts in the other habitats of the deep ocean and in shallow water. Tube worms in the genera Riftia, Ridgeia and Lamellibrachia may reach 2-3 m length and vesicomyid clams and bathymodiolin mussels commonly attain adult lengths of $20-30 \mathrm{~cm}$, all fuelled by their endosymbiotic bacteria. Although these species grow at different rates depending on environmental conditions, most are long lived (Lutz et al., 1988, 1994; Roux et al., 1989; Tunnicliffe et al., 1997; Cordes et al., 2003, 2007), with an age estimated for the coldseep tubeworm Lamellibrachia of 200 years (Bergquist et al., 2000).

A comparative analysis of the nematode size at bathyal and hadal depths in the South Pacific Ocean (Atacama Trench) revealed a reduction of the mean nematode size by ca. $67 \%$ at the deepest depths (Gambi et al., 2003). However, since food availability is not a limiting factor in hadal sediments, other causes are likely to be responsible for the reduction of nematode species richness and body size. The dominance of opportunistic species, which are known to be characterized by smaller sizes, might have contributed to the overall reduced nematode size at hadal depths. Finally, specimens of smaller size may be able to tolerate better the high pressures (Gambi et al., 2003). 
Within species, as well as among species of the same taxa or functional groups, both trends of dwarfism and gigantisms co-exist in the deep sea and not all of them can be explained by food limitation only. Other selective pressures may interplay on the evolution of body size, such as predation, competition or life history. Contradictory patterns and conflicting theories might thus suggest that selective agents act in idiosyncratic ways on different species (Rex et al., 1998). Still, there seems to be one rule regarding the size of benthic deepsea organisms. Deep-sea communities tend to get smaller at increasing depth because the relative contribution of the smaller size-classes to community biomass increases with depth. This observation formed the basis of Thiel's (1979) contention that the average size of organisms decreases with depth, but it was restricted to a comparison between meiofauna and macrofauna biomass in limited datasets. It has only recently been confirmed for all size classes, including bacteria and Megafauna, using much larger datasets (Rex et al., 2006; Rowe et al., 2008).

\subsection{Trophic structure}

Nutritional adaptations play a strong role in determining the taxonomic composition and morphological attributes of the deep-sea biota (Gage, 2003). With low energetic inputs mainly of detritus coming from the surface, detritivores are not surprisingly dominant on the deep seafloor. In fact, the deep sea may have been a centre of diversification for deposit feeders. An increase in palaeo-primary productivity and climate seasonality in the latest Cretaceous - early Palaeogene may explain the origin of many independent deep-sea lineages of detritivore echinoids between 75 and $55 \mathrm{Myr}$ ago (Smith and Stockley, 2005). Different modes of food acquisition, however, are each best represented in different environments: subsurface deposit feeding (e.g. some polychaetes, echiurans) dominates on organic-rich margin sediments, surface deposit feeding (e.g. holothurians, other polychaetes, some asteroids) is well represented in the oligotrophic abyssal seafloor, suspension-feeding (e.g. corals, sponges, crinoids) dominates on slopes of seamounts, canyons, ridges and banks where currents are stronger, chemoautotrophy is the main feeding mode in reducing ecosystems such as vents and seeps, and carnivory and scavenging (e.g. crustaceans, some asteroids, fishes) are found throughout. Although most of the deep sea is heterotrophic (i.e. there is not autochthonous primary productivity and the fauna depends ultimately upon production in the euphotic zone), microbial primary productivity fuelled by chemical energy is found in a number of isolated ecosystems such as hydrothermal vents, cold seeps, OMZs and large food falls.

While food type will determine the community composition in each habitat, food quantity and quality are the most important parameters that shape spatio-temporal variations of abundance, biomass and, in some cases, species richness (Gage, 2003). High diversity on hard substrata in the deep sea is associated with biogenic structures formed by scleractinian, gorgonian or sponge skeletons, giant protozoan tests, bivalve beds and siboglinid bushes (Buhl-Mortensen et al., 2009; Cordes et al., 2009). These structure-forming taxa are often termed ecosystem engineers because of their strong influence on flow and geochemical regimes (Coleman and William, 2002). Associated animals are provided with stable surfaces for attachment, access to more food, sometimes in the form of enhanced particle flux, mucus or associated bacteria, refuge from predators and aggregation sites for mating. Although not unique to the deep sea, commensal relationships involving ecosystem engineers in the deep sea are often facultative, but nevertheless important. Obligate commensal relationships are more common in settings subject to sulphide and oxygen stress such as hydrothermal vents and methane seeps. Examples include large clams and mussels whose gills and mantle cavities host obligate polynoid, nautiniellid and hesionid polychaetes and even a copepod, or siboglinid tubeworms with an obligate egg-consuming bivalve. In these settings, many endosymbiotic bacteria live in obligate relationships with their hosts, and in some taxa are passed down to offspring of the host at the egg stage (e.g. vesicomyid bivalves) or embryo stage (Cary and Giovanni, 1993).

\subsection{Specific adaptations to living in mid water}

The deep pelagic is vast, with generally low abundances of inhabitants, although submersible observations indicate that some species may concentrate into narrow depth bands (Robison, 2004). Such an environment implies low encounter rates for both food and potential mates. Availability of food is even lower than on the deep seafloor because sinking food accumulates at the seabed, but passes through the water column (Herring, 2002). The popular concept of deep-sea animals such as fishes with large mouths and long, sharp teeth results from the fact that these fishes need to catch and swallow whatever prey they chance upon or can lure into range.

In the pelagic environment, organisms must stay at the appropriate depth range. This means actively swimming against gravity (energetically costly in a food-poor environment), increasing drag to prevent sinking, or achieving neutral buoyancy (Herring, 2002). The latter can be accomplished by special flotation structures to offset the weight of muscles and skeleton or by reducing the overall density of the tissue to close to that of seawater. Reduction of tissue density to a gelatinous/watery consistency is very common among deep pelagic animals and is found in many phyla (Herring, 2000). Furthermore, as more direct observations have been made with submersible, it has become apparent that the deep pelagic fauna is dominated by gelatinous megaplankton (Robison, 2004; Robison et al., 2010), such as cnidarians (jellyfishes and siphonophores), ctenophores and salps (Fig. 5). Although little is known about their feeding rates, their sheer abundance indicates their predatory impact on the ecosystem. 


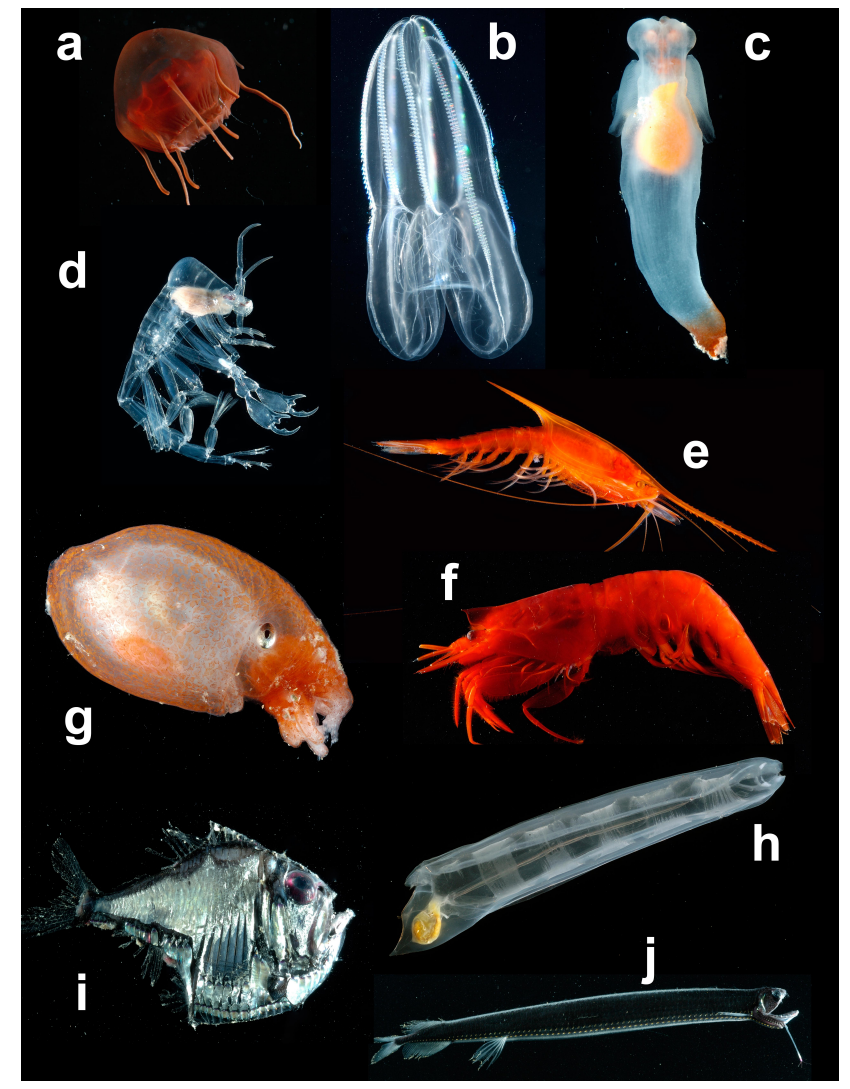

Fig. 5. An assortment of deep pelagic animals. (a) Aeginura grimaldii (a cnidarian jellyfish); (b) Bolinopsis sp. (a ctenophore comb jelly); (c) Clione limacine (a gastropod mollusc, or swimming snail); (d) Phronima sp. (an amphipod crustacean arthropod that lives inside a salp); (e) Gnathophausia sp. (a lophogastrid crustacean arthropod); (f) Ephyrina sp. (a decapods crustacean arthropod, or shrimp); (g) Bolitaena pygmaea (an octopod cephalopod mollusc); (h) Iasis zonaria (a urochordate chordate, or salp); (i) Argyropelecus sp. (a vertebrate chordate, or hatchetfish); (j) Stomias boa (a vertebrate chordate, or scaly dragonfish). All photos by David Shale, MAR-ECO project, taken on the G. O. Sars cruise to the Mid-Atlantic Ridge, summer 2004.

Evidence also is now developing that many other members of deep-pelagic food webs are dependent either directly or indirectly on these gelatinous organisms.

Bioluminescence is common in many marine communities and it is not unusual on land, but it is almost universal among deep-pelagic organisms (Widder, 2010). Some animals produce the light independently, whereas others have symbiotic luminescent bacteria. Biological production of light comes in many forms and has many functions (Herring, 2000, 2002 and references therein). Examples include a variety of lures, searchlights, species- and sex-specific mate signalling/recognition photophores and various forms of predator distraction and avoidance (Widder, 2002). A common form of bioluminescence that has evolved repeatedly among deep-pelagic animals, especially the vertical migrators of the mesopelagic, is counter-illumination. Ventral photophores produce light that matches the faint blue remnant of sunlight coming from above and disrupts the silhouette of the animal when seen from below by a predator.

\section{Deep-sea diversity patterns}

\subsection{One of the highest diversities on the planet}

It was not until the adoption of fine mesh $(250-500 \mu \mathrm{m})$ sieves in the 1960s that the high diversity of benthic deepsea fauna, mainly found in the macrofauna component, was truly appreciated (Hessler and Sanders, 1967), with as many as 100 species collected per $0.25 \mathrm{~m}^{2}$ of seabed (Snelgrove and Smith, 2002). Prior to that, techniques used in shallow water sampling (i.e. sieves with a mesh size of $1 \mathrm{~mm}$ ), were employed for deep-sea samples, thus losing many of the smaller fauna. With increasing sampling and therefore increased number of individuals and species, patterns of standing stock and diversity began to emerge. In many areas of the open deep sea, an exponential decline of macrofaunal standing stock with increasing depth is seen (Rowe, 1983; Rex et al., 2006) and is often related to the flux of particulate organic matter from the surface of the ocean to the seafloor (Johnson et al., 2007). Where there is high surface productivity (e.g. in upwelling areas), and therefore a significant flux of POC to seafloor, this is reflected by the increase in the biomass of the benthos.

Trends in macrofaunal diversity vary both within and among ocean basins. It is often stated that macrofaunal diversity tends to show a parabolic distribution with depth, particularly in the North Atlantic (Rex, 1981, 1983), with the peak generally occurring at intermediate to bathyal depths (Rex, 1981; Maciolek et al., 1987a,b). However, the depth at which the peak in diversity is reached varies tremendously and also depends on the taxa investigated. Paterson and Lambshead (1995) found that, for polychaetes, the highest number of species was seen between 1400-1800 $\mathrm{m}$ along the Hebridean Slope, NE Atlantic, whilst Cosson-Sarradin et al. (1998) saw a parabolic shaped curve in polychaete diversity with depth in the tropical NE Atlantic, with the maximum occurring at a depth of $2000 \mathrm{~m}$. Gage et al. (2000) found that macrofaunal diversity peaked at about $1400 \mathrm{~m}$ along the Scottish continental slope, although in the Faroe-Shetland Channel, the genus-level diversity maximum occurs at depths between 450 and $550 \mathrm{~m}$ (Bett, 2001; Narayanaswamy et al., 2005, 2010). To confuse the issue, bivalves (Allen and Sanders, 1996) and gastropods (Rex et al., 1997) have a variety of patterns in the different basins of the South and North Atlantic. Rex et al. (1997) found that in the NE Atlantic, gastropod diversity reached a minimum at intermediate depths. Weishappel and Svavarsson (1998) showed that amphipods collected from the continental shelf to a depth of $1200 \mathrm{~m}$ in the Norwegian Sea showed no clear pattern, yet south 
of Iceland the amphipod diversity increased with increasing depth over the same depth range.

The great variation in diversity patterns observed for the macrofauna cannot be explained by any one factor. Physical changes in the substratum inhabited by the macrofauna can lead to changes in diversity. For example, Etter and Grassle (1992) suggested that sediment particle diversity may influence diversity as there is greater habitat complexity or greater food diversity. As stated above, productivity influences standing stock, yet it may also have an effect on the benthic diversity. In some areas, high input of particulate organic carbon to the seafloor may result in a decline in diversity (Levin et al., 1994; Gage, 1997) compared to faunal communities found at similar depths (Levin and Gage, 1998). A study of ophiuroid diversity on seamounts has shown that while temperature (or a highly colinear factor such as depth) appears to have high predictive value, modelled POC flux did not (O'Hara and Tittensor, 2010). In order to try and characterise global macrofaunal patterns, intensive sampling spanning both the bathyal and abyssal plains needs to be undertaken, along with a standardised collection technique, consistent taxonomic identification and the same statistical analysis.

\subsection{Hidden but significant: deep-sea meiobenthos}

As faunal community structure, including the taxonomic composition of benthic communities, is tightly related to sediment characteristics, one could expect a significant homogeneity at higher taxonomic levels in soft deep-sea sediments. Indeed, at the phylum or class level, these habitats are relatively predictable in community composition, on the condition that general environmental conditions prevail, such as organic carbon supply, oxygen availability and the presence of a clay ooze substratum. For macrofauna in general, polychaetes are dominant in terms of densities, followed by small crustaceans and gastropods (Cosson et al., 1997; Galéron et al., 2001). In the meiobenthic size class, nematodes are the most successful metazoan higher taxon, representing 90 to 99\%, while foraminiferans equal or even surpass nematodes numerically when the protozoan fraction is considered also as part of the meiobenthos. Harpacticoids are present in soft, well-oxygenated deep-sea sediments but at lower densities, representing less than $10 \%$ or even $5 \%$ of the total small to medium-sized benthos between $33 \mu \mathrm{m}$ and $1 \mathrm{~mm}$. A general review on North East Atlantic meiobenthos is given in Vincx et al. (1994), but all other geographical areas studied support parallel communities at higher taxon level.

Nematodes become increasingly dominant, in terms of relative abundance and species richness, with increasing water depth (Vincx et al., 1994; Soltwedel, 2000). Although the distribution of nematode genera across different deep-sea environments is rather uniform (Thistle and Sherman, 1985; Vincx et al., 1994; Soetaert and Heip, 1995), there is little overlap of nematode species composition between adjacent sites (Jensen, 1988; Tietjen, 1989). Knowledge of nematode species is limited to the Mediterranean (Vitiello, 1976; Soetaert et al., 1995; Danovaro et al., 2008b), the North Atlantic (Tietjen, 1976; Dinet and Vivier, 1979; Jensen, 1988), the Clarion-Clipperton fracture zone (Lambshead et al., 2003; Miljutina et al., 2009) and the Atacama slope and trench (Gambi et al., 2003). Moreover, most of these studies use species identifications only for biodiversity measurements without providing information on species composition and turnover. The majority of deep-sea nematode studies concentrate on genus level investigations, including recent studies from the NE Atlantic (e.g. Vanaverbeke et al., 1997b), the Mediterranean (e.g. Lampadariou and Tselepides, 2006), the South West Atlantic (e.g. Netto et al., 2005) and the Indian Ocean (e.g. Muthumbi et al., 2004), but also the polar regions with studies of the Laptev Sea (e.g. Vanaverbeke et al., 1997a), the Central Arctic (e.g. Vanreusel et al., 2000), the Greenland Margin (e.g. Fonseca and Soltwedel, 2007) and the Antarctic (e.g. Vanhove et al., 1999, 2004).

Deep-sea sediment samples in general are characterized by the presence of a high number of nematode genera (about 20 to 60 genera per 200 individuals on average). However comparison of diversity as taxon richness among samples is difficult because of the high number of rare genera, and consequently also the sample-size dependency of genus richness estimates. Well-oxygenated, soft deep-sea sediments are never characterized by extreme high dominances - exceeding $30 \%$ of the total assembly - of particular genera. In general the dominant genus represents about $10 \%$ or less of the total community, whereas more than half of the genera each represent $1 \%$ or less of the total sample. There is a high degree of divergence in rare genera even between samples from the same area, but there is a high degree of similarity in dominant genera all over the world (Vanreusel et al., 2010). From $200 \mathrm{~m}$ depth downwards, specific genera appear or become more abundant compared to shallow water sites along shelves. Some typical deep-sea genera include Acantholaimus, Thalassomonhystera and Halalaimus, the first two rarely recorded in shallow waters but all three present with relatively high numbers from $200 \mathrm{~m}$ down to the deep trenches all over the world (Soetaert et al., 1995; Gambi et al., 2003; Danovaro et al., 2008b, 2009).

\subsection{High levels of new biodiversity in the Southern Ocean}

The Southern Ocean (SO) covers an area of 34.8 million $\mathrm{km}^{2}$, with most of it being below $1000 \mathrm{~m}$ depth (Clarke and Johnston, 2003). Rex et al. (1993) and Poore and Wilson (1993) documented a latitudinal gradient in deep-sea biodiversity, especially for the Northern Hemisphere. No ecological surveys to the SO deep-sea benthos that included meio-, macroand megafauna were conducted until recently. Intensive investigations since 2002 at about 40 stations in the SO during the ANDEEP (ANtarctic benthic DEEP-sea biodiversity: 
colonisation history and recent community patterns) expeditions revealed that, for some taxa (e.g. Isopoda), more species are known in the benthic deep SO than on the Antarctic continental shelf (Brandt and Hilbig, 2004; Brandt and Ebbe, 2007; Brandt et al., 2007a, b, c). In many taxa, far more than $90 \%$ of the species collected in a typical abyssal sediment sample are new to science (e.g., Nematoda, Crustacea) and many of these (>50\%) are rare. Some authors have demonstrated that the occurrence of rare species in samples is the result of sampling the regional fauna only (Rex et al., 2005a). Patterns in the biodiversity and biogeography of the deep SO differ between meiofaunal, macrofaunal and megafaunal taxa. This points to the fact that largescale biodiversity and biogeography patterns largely depend on size, biology (feeding mode and reproductive patterns) and mobility of the taxa investigated (compare also Rex et al., 2005b), combined with historical geologic patterns, productivity, predation and the relationship between regional and local species diversity (Witman et al., 2004).

One potential explanation for the high SO deep-sea biodiversity could be that the SO deep sea exhibits unique environmental features, including a very deep continental shelf, a weakly stratified water column and formation of abyssal waters flowing to other basins. These characteristics imply that SO deep-sea faunas may be related both to adjacent shelf communities and to those in other deep oceans. Unlike shallow-water Antarctic benthic communities, which display high levels of endemism, gigantism, slow growth, longevity and late maturity, as well as adaptive radiations that have generated considerable novel biodiversity in some taxa (Brandt et al., 2007b, c), little is known about life in the SO deepsea region. However, the recent ANDEEP sampling expeditions in the deep Weddell Sea and adjacent areas (748 to $6348 \mathrm{~m}$ water depth) have revealed high levels of novel biodiversity. The foraminifera were represented by 158 live species, the nematodes belonged to typically cosmopolitan deep-sea genera, but more than half of the 57 species recognised in selected genera were new to science. More than 100 ostracod species were distinguished, with over $70 \%$ of them new. Macrofaunal isopods were astonishingly diverse, with 674 species identified, compared with 371 species reported from the entire Antarctic continental shelf. More than 200 polychaete species were recognised, 81 of them previously unknown. Moreover, samples yielded 160 species of shelled gastropods and bivalves, compared to 279 species known from the shelf $(<1000 \mathrm{~m})$. In addition, 76 species of megafaunal sponges were recognised, with 17 of them new to science and 37 new for the SO (Brandt et al., 2007c). However, whether this high biodiversity is because the Weddell Sea is a geologically old oceanic crust dating from the Middle Jurassic, around $180 \mathrm{Ma}$ ago (Storey, 1995; Thomson, 2004), or because it is a major source of the world's deep water production, which could enhance the deposition of organic matter to the SO deep-ocean floor, needs to be tested in future expeditions.
Bathymetric and biogeographic trends varied among taxa. In groups such as the isopods and polychaetes, slope assemblages included species that have invaded from the shelf. In other taxa, the shelf and slope assemblages were more distinct (e.g. Porifera, Mollusca). Abyssal faunas showed stronger links to other oceans, particularly the Atlantic, but mainly in taxa with good dispersal capabilities such as some foraminifera and some polychaetes (Brandt et al., 2007b, c). However, this general picture might change when more deepsea stations are sampled, as well as other SO areas. The isopods, ostracods and nematodes are poor dispersers and, thus, include many species currently known and sampled only from the SO. Our findings challenge suggestions that deep-sea diversity is depressed in the SO at least for the south Atlantic sector. Moreover, these data provide a basis for exploring the evolutionary significance of the varied biogeographic patterns observed in this remote environment (Brandt and Hilbig, 2004; Brandt et al., 2007b, c; Brandt and Ebbe, 2007 and references therein).

\subsection{Characteristic fauna from the deepest ocean}

Trench fauna differ from abyssal communities (Gambi et al., 2003) and already since the mid 20th century, Bruun (1956) described systems below $6 \mathrm{~km}$ depth as a unique ecological realm: the hadal zone (Blankenship-Williams and Levin, 2009). The biota of trenches which occur below $6000 \mathrm{~m}$ are referred to as ultra-abyssal or hadal. Although exploration and sampling of hadal fauna is still very limited, the number of metazoan species available for analyses from depths of over $6000 \mathrm{~m}$ has been constantly increasing in the last 60 years. Numerous new species, genera and families have been described from hadal systems, with underwater photographs revealing new groups of animals yet to be identified (Belyaev, 1989). For many years, fishes and decapods were considered to be excluded from hadal settings, but recent lander-based observations reveal liparid fishes and shrimp present to depths of at least $7700 \mathrm{~m}$ in the Pacific (Jamieson et al., 2010). Videos show that many of these consume scavenging amphipods. The nekton in the zone between 6000 and $11000 \mathrm{~m}$ is dominated by carnivorous, cannibalistic and scavenging amphipods, with decapods and fishes limited largely to depths less than $8000 \mathrm{~m}$ (Jamieson et al., 2010). Studies of the Kermadec and Tonga trenches using baited traps reveal that four amphipod species partition the $6000-11000 \mathrm{~m}$ water column vertically, and that several species also exhibit ontogenetic vertical zonation (Blankenship et al., 2006) as well as resource partitioning by diet (Blankenship and Levin, 2007). Calcareous taxa fare poorly in this zone. In the echinoderms, ophiuroids, echinoids and asteroids disappear while holothurians are abundant (Wolff, 1970; Belyaev, 1989). The great trench depths are linked to under-saturation of carbonate and opal. Foraminifera are dominant forms at the greatest ocean depths (Todo et al., 2008), but most are soft-bodied or organic-walled and 
calcareous forms are rare (Gooday et al., 2008). Amphipods, polychaetes and bivalves are more abundant in the hadal zone than in the abyss, while cnidarians, bryozoans and cumaceans are rare (Wolff, 1970). Levels of endemism appear to be extremely high (58\%) among the hadal fauna, at least for larger taxa, with $47 \%$ of species limited to single trenches (Belyaev, 1989). It seems that each trench harbours a distinct community. Chemosynthesis-based communities are also present in trenches. Although biodiversity within a hadal trench is often low, because of their characteristic fauna, hadal systems may contribute significantly to global deep-sea diversity (Blankenship-Williams and Levin, 2009). The extent and importance of trenches, the degree and mechanisms of gene flow between trenches, and the evolutionary age of the trench fauna are some of the many remaining questions concerning hadal ecosystems (Blankenship-Williams and Levin, 2009).

The diversity of nematode assemblages at hadal depths in the Atacama Trench (Pacific Ocean) displays a different composition to that at bathyal depths (Gambi et al., 2003). At bathyal depths, 95 genera and 119 species were found (Comesomatidae, Cyatholaimidae, Microlaimidae, Desmodoridae and Xyalidae being dominant). In contrast, in the Atacama Trench, despite the very high abundances of over 6000 individuals in $10 \mathrm{~cm}^{-2}$ (i.e. 10 times the abundance of meiofauna at bathyal depths; Danovaro et al., 2002), only 29 genera and 37 species were found, dominated by Monhysteridae, Chromadoridae, Microlaimidae, Oxystominidae and Xyalidae. The genus Monhystera (24.4\%) strongly dominated at hadal depths and Neochromadora and Trileptium were observed only in the Atacama Trench. The presence of a restricted number of families and genera in the Atacama Trench might indicate that hadal sediments limited nematode colonisation. Most of the genera reaching very high densities in Trench sediments (e.g., Monhystera) are opportunistic (Gambi et al., 2003).

\subsection{Lophelia reefs: hot spots of diversity}

The complex structure of coral reefs provides habitats and refuges to a variety of associated fauna and it has been shown that the biological diversity of some cold-water coral reef communities can be three times as high as the surrounding soft sediment (Henry and Roberts, 2007), suggesting that these reefs may be biodiversity hotspots. The reefs commonly harbour abundant sessile suspension feeders and a multitude of grazing, scavenging and predatory invertebrates such as echiurans (e.g. Bonellia sp.), molluscs (e.g. Acesta excavata), crustaceans (e.g. Pandalus spp., Munida spp.) and echinoderms (e.g. Cidaris spp., Gorgonocephalus sp.) (Hovland, 2008; Roberts et al., 2006, 2008). Although the inventory is ever growing, currently over 1300 species have been reported from cold-water coral reefs, some of which are new to science (Myers and Hall-Spencer, 2004; Mortensen and Fosså, 2006; Henry and Roberts, 2007; Guerra-Garcia,
2008). There are also biogeogrpahic variations in the species found associated to Lophelia and an overall biodiversity decrease from south to north (Hall-Spencer et al., 2002, 2007; Roberts et al., 2008). The Lophelia reefs found in the NE Atlantic are complex habitats with coral colonies up to ca. $2 \mathrm{~m}$ high and fragments of dead skeleton of variable size and age (Wilson, 1979; Mortensen et al., 1995; Hovland and Mortensen 1999). They provide habitat for a variety of species and therefore support a significant biodiversity (Dons, 1944; Jensen and Frederiksen, 1992; Mortensen and Fosså, 2006; Henry et al., 2007, 2010). The majority of these species are sessile invertebrates that use the exposed skeleton as an attachment site in an environment suitable for suspension feeding. Habitats within the Lophelia reefs can be defined at different spatial scales (Mortensen et al., 1995; Jonsson et al., 2004; Foubert et al., 2005; De Mol et al., 2007; Wienberg et al., 2008). Viewed at a large scale, a reef typically consists of three vertical zones, or reef habitats: (1) "The live Lophelia-zone" (LL) occurs at the top of the reef and consists of mainly living Lophelia colonies separated by areas with dead broken skeletons. (2) "The dead Lophelia-zone" (DL) is found between the top and the foot of the reef. The bottom here is characterised by large fragments of dead corals, and a high diversity of megafauna. (3) "The Lophelia rubble-zone" (LR), has small skeletal fragments mixed with sediments flanking the foot of the reef. The horizontal extent of this zone varies from only a few metres to several tens of metres. The live and the dead zone comprise steep bottoms and normally have a similar vertical range, whereas the Lophelia rubble-zone has a narrower depth range and a lower bottom inclination. At a smaller scale, four sub-habitats can be recognised within the coral colonies: (1) the smooth surface of living corals, (2) the detritus laden surface of dead corals, (3) the cavities inside dead skeleton, and (4) the free space between the coral branches (Mortensen et al., 1995). The composition of associated species is clearly different in these sub-habitats but has been limited studied (Wienberg et al., 2008; Jensen and Frederiksen, 1992). More studies on the small-scale distribution of species within Lophelia-reefs are needed to understand the habitat requirements of the species and to learn more about the structure and functioning of the reef community (Henry et al., 2007, 2010; Mastrototaro et al., 2010; D’Ongia et al., 2010).

The highest documented density of Lophelia-reefs is found off the Norwegian coast, where more than 1000 reefs have been documented and more than 6000 have been estimated. On the open coast Lophelia reefs occur in offshore areas mainly between 200 and $300 \mathrm{~m}$ depth, whereas in some of the deep, open fjords they occur shallower, up to $40 \mathrm{~m}$ depth. It is the vertical distribution of warm $\left(4-8^{\circ} \mathrm{C}\right)$ Atlantic water that restricts $L$. pertusa to the upper $400 \mathrm{~m}$ in the Norwegian Sea and the Barents Sea. Below this depth, cold $\left(-0.5-4{ }^{\circ} \mathrm{C}\right)$, Arctic intermediate water occurs. The area west of the British Isles represents another prominent reef 
province. In this region cold water occurs much deeper than it does north of the Wyville-Thomson Ridge. L. pertusa is here found in two depth strata: one shallow (200-400 m) and one deep (700-900 m). Another scleractinian, Madrepora oculata commonly occurs together with Lophelia pertusa in the Northeast Atlantic. However, Madrepora is less abundant than Lophelia and has never been reported forming coral reefs (Dons, 1944; Frederiksen et al., 1992). Cairns (1979) observed that such Lophelia-Madrepora associations are typical for eastern Atlantic deep-water coral reefs, in contrast to the Lophelia-Enallopsammia associations of most western Atlantic deep-water coral reefs. Other scleractinians e.g. Dendrophyllia cornigera (Lamarck, 1816), Desmophyllum dianthus, Gonicorella dumosa (Alock, 1902), Solenosmilia variabilis (Duncan, 1873) and Oculina spp. are often found together with Lophelia in different parts of the world. Along the mid-Atlantic Ridge, there are signs of former large Lophelia-reefs, but the live occurrences are restricted to scattered small colonies (Mortensen et al., 2008). Mortensen et al. (2006) found no evidence that this situation was due to intensive bottom fisheries, but suggested rather that climatic changes could have led to less favourable environmental conditions or reduced food supply. In the Meditterean Sea, living cold-water corals are much more limited in extend and density than the Atlantic Ocean. The dominant living species seems to be Desmophyllum dianthus and Dendrophyllia cornigera. Additionally, a few refuges of framework building corals have been reported of Madrepora occulata (Orejas et al., 2009) and Lophelia pertusa (Tursi et al., 2004). Gorgonians occurring in stands are called gorgonian "gardens". Such habitats may consist of one or several species of gorgonians and are confined to hard bottom, except for some species of Isididae and Chrysogorgiidae, which attach to sandy and muddy bottoms with rootlike holdfasts. Primnoa resedaeformis and Paragorgia arborea are the most abundant and widely distributed large gorgonians in the North Atlantic (Madsen, 1944; Tendal, 1992; Mortensen and Buhl-Mortensen, 2004; Mortensen et al., 2006). The diversity of associated species - including commensalistic, parasitic and mutualistic relationships with both strong (obligate) and loose (facultaive) associations with cold-water gorgonians is lower than for cold-water scleractinians (Buhl-Mortensen and Mortensen, 2005). However Buhl-Mortensen and Mortensen (2005) found that the number of obligate symbionts is higher for gorgonians than for antipatharians, alcyonarians and scleractinians.

\subsection{Diversity in the pelagic system}

In the pelagic system, the abundance and biomass of organisms generally varies with depth, from a maximum near the surface, decreasing through the mesopelagic, to very low levels in the bathypelagic, increasing somewhat in the benthopelagic (Marshall, 1979). It is worth noting that although the abundance (i.e., number per cubic meter of seawater) of animals in the bathypelagic is very low, because such a huge volume of the ocean is bathypelagic, even species that are rarely encountered may have very large total population numbers. A species with only one animal in $1000 \mathrm{~cm}^{3}$ of water but a depth range of 1-2 km and a broad geographic distribution can have a population of many millions (Herring, 2002). The organisms of this huge ecosystem may be very diverse, but their diversity is so poorly known that it cannot even be estimated reasonably for comparison with other ecosystems (Robison, 2009).

Temporal dynamics in the pelagic system have a major impact in the shaping of the ecosystem (Robison, 2004; Robinson et al., 2010). These temporal changes, ranging from daily to annual, result from both physical and biological processes. Water movements transport entrained swimming and drifting organisms. Because of the huge volume of water moving in the deep, even slow currents can transport very large numbers of organisms, and on annual time scales the distances can be large. Temporal biological dynamics include the active vertical movements of the animals over various time scales. The life cycles of deep-pelagic animals often involve shifts in vertical distribution among developmental stages. Additionally, many deep-benthic species spend part of their life cycles, typically the early stages but for some the reproductive stage, at some level in the pelagic realm (Marshall, 1979). Such ontogenetic vertical migrations expand the dependence of species on the physical and biological dynamics of the various layers, often including the surface layer. Even more spectacular are the diel vertical migrations of very many species typical of the mesopelagic and upper bathypelagic (Angel, 2003). Although there are various detailed patterns, this shift is generally upward at night to feed in the higher biomass closer to the surface and back down during the day, perhaps to avoid visual predators during daylight or perhaps for energetic efficiency in the colder, deeper waters. Diel vertical migration in the deep sea comprises the largest migration on Earth. The argument has recently been made that so many animals are swimming up and down regularly that they add substantially to the physical mixing of the ocean water (Kunze et al., 2006). All of this vertical migration also actively contributes to the "biological pump" that substantially accelerates the movement of carbon compounds and nutrients from the epipelagic into the deep ocean (Angel, 2003). When the temporal component is superimposed on the massive volume of the deep ocean, the deep pelagic can be considered to be effectively four-dimensional.

Horizontal patterns exist in the global distribution of deep pelagic organisms (Herring, 2002). However, these patterns seem less distinct than in either surface waters or on the bottom. The drivers of these patterns are not well known. Primary productivity at the surface is certainly an important factor. Whether by passive sinking or active biological transport, surface productivity feeds life in the deeper waters. Surface patterns are therefore reflected in the deep pelagic (Herring, 2002). In addition to variation in the total abundance 
and biomass that can be supported, some deep species are known typically to live beneath oligotrophic waters whereas others are typical below higher productivity areas, even areas where high productivity drives low oxygen concentrations in underlying waters. Additionally, major oceanic frontal boundaries such as the polar and subpolar fronts extend down into deep waters and appear to form biogeographic boundaries, although the distinctness of those boundaries may decrease with increasing depth (Vecchione et al., 2010).

\subsection{Large-scale diversity trends}

Two large scale diversity patterns have been discussed in the context of deep-sea benthic communities: a poleward trend of decreasing diversity and the unimodal relationship between diversity and depth (Rex, 1981; Rex et al., 1993). Indeed, for many taxa, a parabolic pattern in species diversity in relation to water depth has been observed (Rex, 1981; Pineda and Caswell, 1998; Gray, 2001, 2002; Levin et al., 2001). This pattern and the latitudinal pattern in species richness may be explained by biological interactions, the speciesarea hypothesis, hump-shaped energy-productivity, species ranges, the random boundary hypothesis and historical (evolutionary) factors (Gray, 2001 and references therein).

Because of the lower numbers of individuals per species in deep-sea regions compared to coastal areas and the very large numbers of species collected in individual sledge tows, Hessler and Sanders (1967) first suggested that deep-sea communities are more diverse than those in shallow areas. Since then, the question of whether the deep sea is (hyper) diverse (Gray, 1994, 2002; Gray et al., 1997; Lambshead and Boucher, 2003) and what mechanisms maintain such high diversity (Grassle and Sanders, 1973; Grassle, 1989; Gage and Tyler, 1991; Etter and Grassle, 1992; Lambshead, 1993; Rogers, 2000; Levin et al., 2001; Snelgrove and Smith, 2002; Rex et al., 2005b) have been constantly discussed and remain controversial (May, 1994). According to Gage and Tyler (1991), seasonal food input is one of the factors that is a source of temporal patchiness and regulates species coexistence in the deep sea. Other hypotheses suggest a balance between competitive exclusion and frequency of disturbance, which results in patchiness and community succession on biologically influential scales, i.e. millimetre-to-meter (Grassle and Sanders, 1973; Grassle, 1989; Lambshead, 1993; Snelgrove and Smith, 2002). Additionally, microhabitat specialization may promote local species diversity in deep-sea sediments (Jumars, 1975, 1976; Thistle, 1983, 1998; Thistle and Eckman, 1990; Baguley, 2006). Levin et al. (2001) identified food input, bottom flow, bottom-water oxygen levels, sediment heterogeneity and ecological disturbance as the five most important factors structuring benthic biodiversity in the deep sea.

The pattern of latitudinal decreasing species richness (macrofauna) in the NE Atlantic, or increasing species diversity (nematodes) from the tropics northwards, is probably the most debated (Boucher and Lambshead, 1995; Rex et al., 2000, 2001; Mokievsky and Azovsky, 2002; Lambshead et al., 2000, 2001, 2002; Ellingsen and Gray, 2002). There are still large gaps in the information on the latitudinal pattern of the Northern Hemisphere, especially for nematodes. Diversity measurements in the Arctic were lacking until recently, as studies have been restricted to genus level investigations (Vanaverbeke et al., 1997a; Vanreusel et al., 2000; Fonseca and Soltwedel, 2006). Lambshead (1993) hypothesised that primary productivity is closely coupled to pelagic secondary production in the tropics so that there is little flux to the seabed. Moving polewards, the primary bloom becomes more decoupled from the grazing bloom so that much phytoplankton settles to the seabed, leading to increased food availability at higher latitudes. The relationship between productivity and diversity is thought to be unimodal, with highest diversity at intermediate levels of productivity (Grime, 1973; Huston, 1979; Rosenzweig, 1995). Productivity in benthic deep communities outside reducing environments can be considered low to extremely low, therefore the relationship between productivity and diversity is expected to be linear (Lambshead et al., 2000). Investigation of deepsea metazoan species richness along latitudinal gradients is relatively new and, so far, is restricted to a few macrofaunal taxa (Rex et al., 1993, 1997, 2000), modern and fossil foraminifera (Thomas and Gooday, 1996; Culver and Buzas, 2000) and nematodes (Lambshead et al., 2000). However, studies of faunal diversity along latitudinal gradients have typically used data assembled from a variety of different projects that used different collecting protocols and methods. This problem has contributed to increasing the degree of uncertainty in the interpretation of results. An example of conflicting results is reported from the European margins. Preliminary results, based on a large data set collected under the same sampling strategy and laboratory protocols, are providing new insights into the knowledge of latitudinal patterns (Danovaro et al., 2009). Although limited data were collected along the European open slopes for comparison, the results are significantly different from those expected as both the richness of total meiofaunal taxa and nematode species richness are very similar at all latitudes, with slightly higher values at mid-high latitudes (Fig. 6). However, the very limited information available between $42^{\circ} \mathrm{N}$ and $70^{\circ} \mathrm{N}$ or more and the peculiar characteristics of the deep Mediterranean Sea need to be carefully considered. These new observations beg for new hypotheses based on the combined effect of regional productivity and efficiency of shelf export in different slope areas.

Qualitative (Rex, 1981) and quantitative (Etter and Grassle, 1992) sampling studies indicated that diversitydepth patterns in the benthic deep sea are often unimodal with a peak at intermediate depths (around $2000 \mathrm{~m}$ ) and lower diversity at upper bathyal and abyssal depths (Gray, 2001). Some abyssal regions (e.g. the Equatorial Pacific and Southern Ocean) still have very high diversity (Glover et al., 


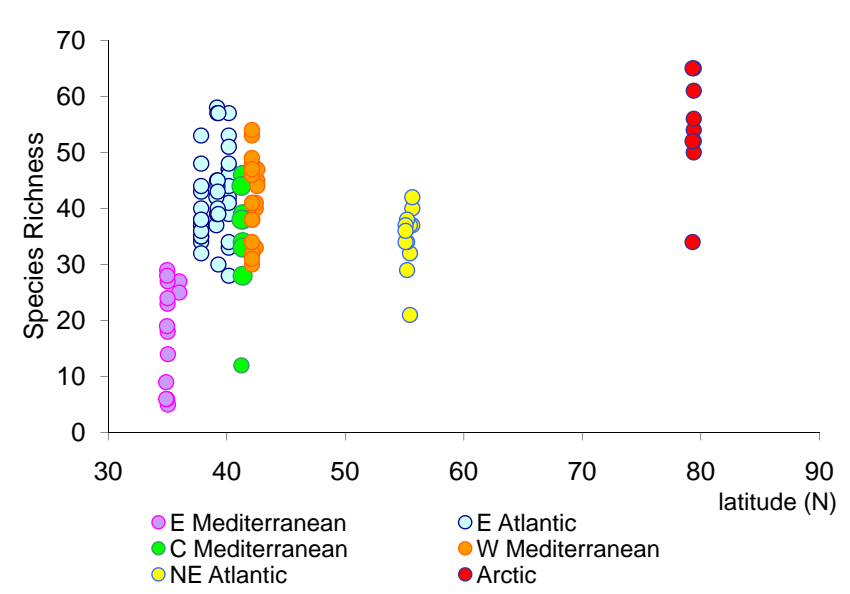

Fig. 6. Latitudinal patterns of benthic biodiversity (expressed as nematode species richness) from deep-sea sediments along continental margins. Reported are the results from: NE Atlantic (Celtic margin), E Atlantic (Portuguese margin), W Mediterranean (Catalan margin), C Mediterranean (Southern Adriatic), E Mediterranean (Cretan margin), Arctic (Nordic margin/Svalbard).

2002; Smith et al., 2008). Unimodal patterns, however, do not appear to be universal (Rex et al., 1997; Stuart et al., 2003). A variety of unanticipated oceanographic conditions, at specific depths, often interrupts and modifies bathymetric horizontal diversity trends (Gage, 1997; Levin and Gage, 1998; Vetter and Dayton, 1999; Levin et al., 2001). Species diversity varies strongly with depth and diversity-depth patterns vary geographically from basin to basin (Rex et al., 1997; Danovaro et al., 2008b). Although diversity-depth trends are not completely understood, it seems likely that they are shaped by complex interacting factors that operate at different temporal and spatial scales (Levin et al., 2001; Stuart et al., 2003).

Our knowledge of bathymetric gradients of diversity is largely based on studies conducted in the bathyal zone (i.e. from the shelf break at $200 \mathrm{~m}$ down to $3000 \mathrm{~m}$ ), and different taxa display different spatial patterns with increasing depth. For example, the analysis of nematode assemblages revealed high biodiversity values along continental margins, but the expected strong unimodal trend over the bathymetric gradient with a diversity peak at $2000 \mathrm{~m}$ water depth (Rex, 1981) was not evident. Therefore, the hump-shaped curve cannot be used to describe the general patterns of meiofaunal biodiversity vs. depth. The number of taxa decreases with increasing depth along the open slopes of most continental margins examined, except the North Atlantic (Rockall Trough; Vincx et al., 1994; Hoste et al., 2007). Moreover, the analysis of deep-sea biodiversity along continental margins at standard depths revealed that no clear spatial (either increasing or decreasing) pattern in nematode diversity can be observed in any of the study areas, except the southern Cretan margin where diversity decreases with depth (Fig. 7). These results suggest that biodiversity patterns also depend

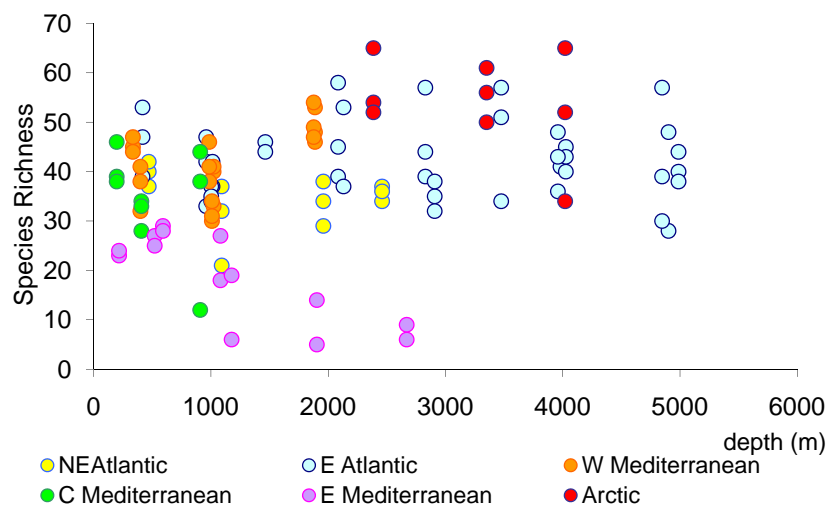

Fig. 7. Bathymetric patterns of benthic biodiversity (expressed as nematode species richness) in deep-sea sediments along continental margins. Reported are the results from: NE Atlantic (Celtic margin), E Atlantic (Portuguese margin), W Mediterranean (Catalan margin), C Mediterranean (Southern Adriatic), E Mediterranean (Cretan margin), Arctic (Nordic margin/Svalbard).

on topographic and ecological features at a regional scale (Danovaro et al., 2009) and underline the importance of acquiring a better understanding of the ecological and environmental conditions acting at regional scales and potentially controlling deep-sea biodiversity distributions along continental margins (Danovaro et al., 2010).

The source-sink hypothesis for macrofauna formulated by Rex et al. (2005b), states that abyssal populations in many species of gastropods and bivalves are regulated by a balance between chronic extinction arising from vulnerabilities to Allee effects (for smaller populations, the reproduction and survival of individuals decrease) and immigration from bathyal sources, with non-reproductive populations at abyssal depths. However, the sources-sink model remains to be tested for other taxa in the North Atlantic, and for all taxa in the largest abyssal basins in the Pacific Ocean (Smith et al., 2008). It does not seem to apply to a number of highly successful and species-rich taxa in the abyss including isopods, polychaetes, holothurians and asteroids (Ramirez-Llodra et al., 2002; Young, 2003 and references therein; Smith et al., 2008 and references therein).

\subsection{Diversity variables that single out deep-sea samples: evenness}

Deep-sea benthic assemblages, excluding those from chemosynthetically-driven systems, are typically characterized by a high diversity and low degree of dominance by the most abundant species. As a consequence, the evenness (equitability, measured as Pielou index, $\mathrm{J}$ ) of the benthic assemblages is generally high, ranging from 0.7 to 1.0 . This means that the distribution of individual abundance is highly homogeneous among species. This property has important 
and positive consequences on the stability of the benthic assemblages as well as on the resilience of these assemblages after a disturbance event. The evenness of deep-sea assemblages has no equivalents with shallow water counterparts (Flach and de Bruin, 1999) and is likely to represent a privileged tool for optimizing the exploitation of the limited food sources generally available in deep-sea ecosystems. An analysis based on a large data set from the European continental margins (Fig. 8; Danovaro et al., 2008a) indicates that at all latitudes and in different biogeographic settings, the evenness of meiofaunal (nematode) assemblages increased with increasing depth. Interestingly, the evenness increased with increasing depth also in systems where the biodiversity showed a clear negative bathymetric gradient. In all of the systems investigated, the Pielou index increased from 500 to $2000 \mathrm{~m}$ depth to remain stable at values close to 0.95 down to $5000 \mathrm{~m}$ depth.

In stark contrast to the diverse, even systems described above, the world's OMZ ecosystems support some of the lowest diversity found in the ocean. Extreme dominance is a hallmark of the OMZ benthos, with single species accounting for over half of the total macrofauna where hypoxia is most severe (Levin et al., 2001, 2009). Strangely enough the dominant form varies from place to place, although these are often annelids. In the Arabian Sea, a spionid and amphinomid polychaete species account for $67 \%$ and $100 \%$ of the total macrofauna at $400 \mathrm{~m}$ off Oman and at $800 \mathrm{~m}$ off Pakistan, respectively. Off Peru, a gutless oligochaete is $83 \%$ of the total and off northern Chile a dorvilleid polychaete is $73 \%$ of the total macrofauna. In the sandy sediments of a seamount bathed in the OMZ off Mexico an aplacophoran mollusc is the dominant taxon (47\% of the total). In the Namibian OMZ the gastropod (Nassarius vinctus) and bivalve (Nuculuna bicuspidata) dominate. Maximal dominance is typically associated with extremely high density or biomass, and seems most likely to occur at OMZ lower transition zones, where oxygen just begins to rise. Often the species richness of these communities is very low, with $10-20$ species. Similar patterns of low diversity and high biomass are found in other ecosystems with strong gradients of environmental factors, such as hydrothermal vents (Van Dover, 2000).

\section{Limitations to deep-sea diversity estimation}

\subsection{Analytical methods}

The deep-sea fauna is unquestionably diverse (Bouchet, 2006), but the question of quite how diverse remains unresolved. Grassle and Maciolek's (1992) benthic extrapolation of at least 1 million and potentially more than 10 million species is, at the upper end, higher than an estimate of total multicellular marine species richness derived from European fauna (Bouchet, 2006), and also higher than ReakaKudla's (1997) estimates of shallow-water coral reef species

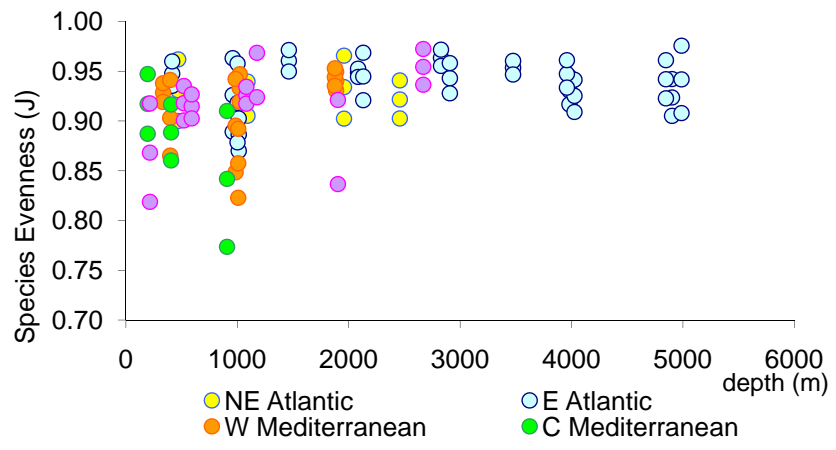

Fig. 8. Bathymetric patterns of evenness of the benthic biodiversity (expressed as Pielou index, J) in deep-sea sediments along continental margins. Reported are the results from: NE Atlantic (Celtic margin), E Atlantic (Portuguese margin), W Mediterranean (Catalan margin), C Mediterranean (Southern Adriatic), E Mediterranean (Cretan margin).

richness. Thus it appears that the deep sea has a particularly high level of uncertainty associated with species richness estimates. Unfortunately, the challenges of sampling the deep sea and identifying specimens limit the data available for answering the aforementioned question. Potentially informative data are derived from two connected processes: (1) species discovery - identifying a morpho-species as potentially new at a regional or global level, and (2) species description - describing a new species in the literature. These processes can be compared for deep-sea and shallow-water systems and, in the limiting case of extremely well-sampled and identified taxa, used to extrapolate species richness, assuming that trends in discovery remain consistent.

The extrapolation of species description or discovery curves to estimate total richness has been attempted in the global oceans for large marine animals (Solow and Smith, 2005) and fishes (Mora et al., 2008), and regionally for all European marine species (Wilson and Costello, 2005). Mora et al. (2008) partitioned species explicitly by habitat affiliation, providing some information on discovery trends in deep-sea fishes. Bathydemersal species were the least completely sampled of all fishes by habitat, with a predicted 56\% (2081 species) of species currently in the public inventory, while bathypelagic species were considered to have an inventory $76 \%$ complete (1275 species). However, this study was only conducted on publicly accessible data, meaning that the numerous privately held (and indeed undescribed) data could well inflate this total. Additionally, taxonomic expertise for fishes is primarily distributed among pelagic, shallow-demersal and reef-associated species, with less availability for deep-sea species. Given that fish are among the best-sampled of marine taxa, and that for other taxa there is far more limited taxonomic expertise available to partition specimens into morpho-species or to describe species in the literature, the species description curve 
approach would appear to be of narrow applicability for the deep sea at present.

Another limiting factor is that the large marine databases that have been assembled in recent years, though very valuable resources, are not yet at a stage in which they can be used to examine discovery trends in the deep sea. The World Register of Marine Species (WoRMS; http://www. marinespecies.org) lacks easily extractable information to automatically identify species as deep sea, so without taxonomic knowledge of an entire group it is difficult to extract the data necessary to partition species to shallow/deep-water. The Ocean Biogeographic Information System (OBIS; http: //www.iobis.org) contains over 19.4 million records as of September 2009, but only 75,532 of these are from depths $>1000 \mathrm{~m}$, or approximately $0.004 \%$ of the total. This tiny proportion reflects both the limited deep-sea data in the database and the relative paucity of sampling compared to shallow systems (Webb et al., 2010).

An alternative to examining global description rates is to focus on extrapolation from local or regional discovery curves. Species accumulation curves can be compiled for individual sampling programmes and can (if supported by the data, and accepting the inherent assumptions) be extrapolated to asymptotic richness or to greater spatial extent (Grassle and Maciolek, 1992). For example, the ANDEEP IIII expeditions (Brandt et al., 2004a, b, 2007a, b) sampled 13046 isopods from the deep Southern Ocean (SO) between 2002 and 2005. A total of 674 isopod species were discriminated from the 40 deep stations. Extrapolating the data from Brandt et al. (2007c) using a newly-developed modelaveraging technique (Mora et al., 2008) suggests that the inventory of isopods from the benthic deep SO is $\sim 68 \%$ complete (Fig. 9), with around 314 species remaining to be discovered (but note: these data are from epibenthic sleds only, and the approach assumes that the habitat is well-sampled). This example involves extrapolation from a sampling programme that has gathered and identified a very large number of individuals. For most regions and taxa in the deep sea, this level of sampling is far from being attained. Furthermore, unless the same taxonomists are involved, results cannot be combined from different expeditions because morphospecies are not comparable. The unknowns of beta (turnover) diversity and cosmopolitanism further exacerbate the already significant uncertainties associated with spatial extrapolations.

We therefore suggest, given the challenging combination of limitations in sampling and taxonomic expertise, and the potentially vast diversity of deep-sea environments, that the approach of extrapolating from description and discovery curves is, at present, likely to be of limited utility for estimating deep-sea species richness in the majority of taxa. Extrapolations from species accumulation curves can be useful for those regions and taxa that are particularly well sampled, but these remain few (Table 2). Given these limitations, if revised estimates of deep-sea species richness are to

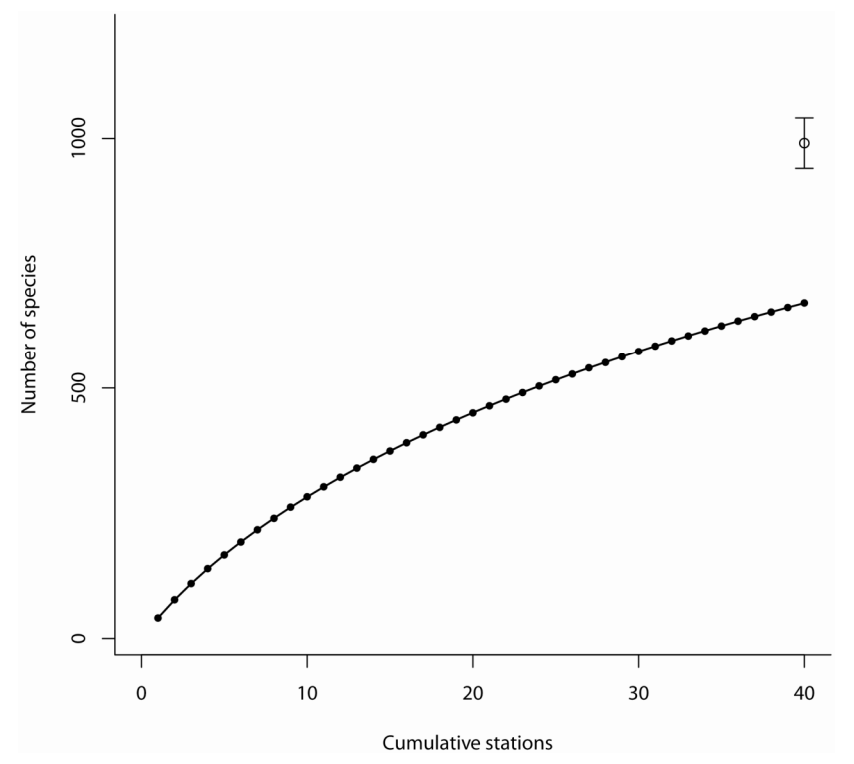

Fig. 9. Rarefied isopod species richness from ANDEEP I-III deepsea stations (filled circles and line) and predicted asymptotic multimodel species richness with $95 \%$ confidence limits (empty circle and associated error bars). The multi-model approach incorporates the uncertainty associated with selecting the "best" model to fit to data. Sampling data are from Brandt et al. (2007). Modelling approach follows Mora et al. (2008) with revised confidence limit calculations.

be made, extrapolating from macroecological patterns (May, 1988) may prove a fruitful avenue for future research.

\subsection{Contrasting species-discovery and description rates}

With the development of sampling techniques, the number of benthic and pelagic samples collected in the last decades has been increasing constantly. However, the number of potentially new species (especially in the macro and meiofauna) and the decreasing number of available taxonomists result in slow description rates. A good example is found in nematodes. In spite of their numerical importance, only a small fraction of all deep-sea nematode species has been described to date. The high number of species, combined with the low numbers of individuals recorded per species, their small body size and the low representations of adults, makes their taxonomic study a nearly impossible task through traditional techniques of microscopical observation. De Mesel et al. (2007) indicated the presence of 55 different morphotypes within the single genus Acantholaimus in a restricted geographical area (15 stations) within the Weddell Sea (180 to $2000 \mathrm{~m}$ depth). The elaborate task of describing this high biodiversity slows the discovery rate of new species as illustrated in Fig. 10. Knowing that one sample of $10 \mathrm{~cm}^{3} \mathrm{can}$ harbour up to 100 different morphologically distinct species, and one study area of a restricted number of stations contains up to 500 or more undescribed species in total, a discovery 


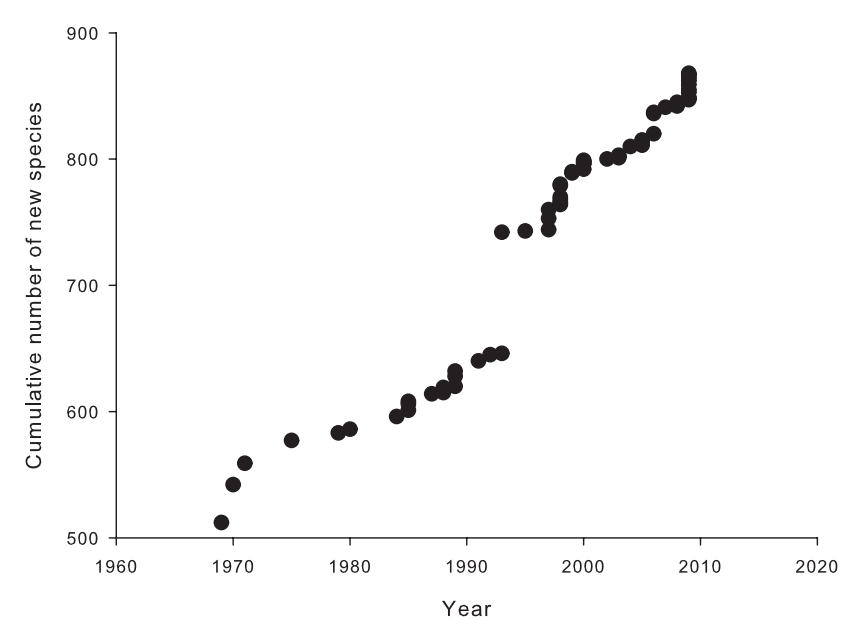

Fig. 10. Rate of new nematode species described from the deep-sea over the last 40 years. Data from A. Vanreusel.

rate of about 350 species over the last 40 years is just a glimpse of the true nematode diversity presents in deep-sea sediments.

The second most abundant metazoan taxon in the deepsea is the copepod crustaceans. A single deep-sea multicorer sample $\left(78 \mathrm{~cm}^{3}\right)$ is likely to contain $50-60$ copepod species (Rose et al., 2005), almost all of them as yet undescribed (Thistle, 1998; Seifried, 2004). In addition most of the species are represented by single individuals, so that the complementarity between samples is very low. The relationship between number of adult copepods sampled and number of species found in samples from abyssal sites in the Pacific and Indian Ocean is a linear relationship with a slope of 0.86 and a regression value of $R^{2}=0.97$, indicating that almost every new adult specimen found represents a different species (Fig. 11). Coull (1972) examined 696 deep-sea copepods from 18 stations in the Northwestern Atlantic, concluding that "very few are duplicated from sample to sample". These figures are similar in different ocean basins, as confirmed by as yet unpublished copepod data from the ClarionClipperton Fracture Zone (Pacific), South Atlantic Basins, Eastern Mediterranean and Basins around the Crozet Islands (Indian Ocean). A single collection of copepods from the Angola basin yielded more than 600 undescribed species of copepods (Seifried, 2004; Rose et al., 2005).

An analysis of the CeDAMar database (www.cedamar. org/biogeography) containing distribution records of species present at depths greater than $2000 \mathrm{~m}$ reveals a great lag between the time that a species is discovered (i.e. collected) and the time when the species description is published, thus becoming available. From a total of 3074 species recorded from abyssal plains and described between 1765 and 2006, only $31 \%$ were described within the first 4 years after discovery, an additional $39 \%$ of the species descriptions were published between 5 and 10 years after discovery and $30 \%$

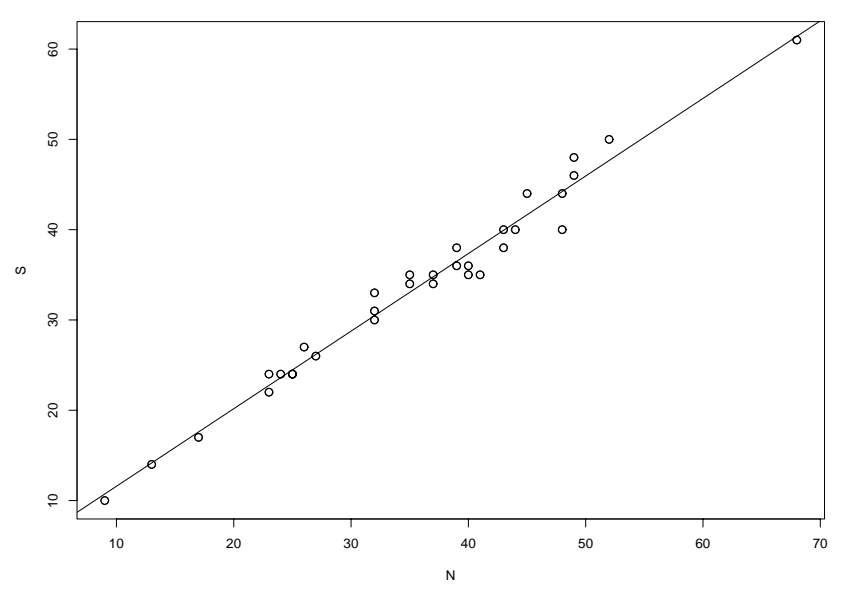

Fig. 11. Relationship between number of adult copepod specimens $(N)$ and number of species $(S)$ in abyssal sediments. Data from P. Martinez.

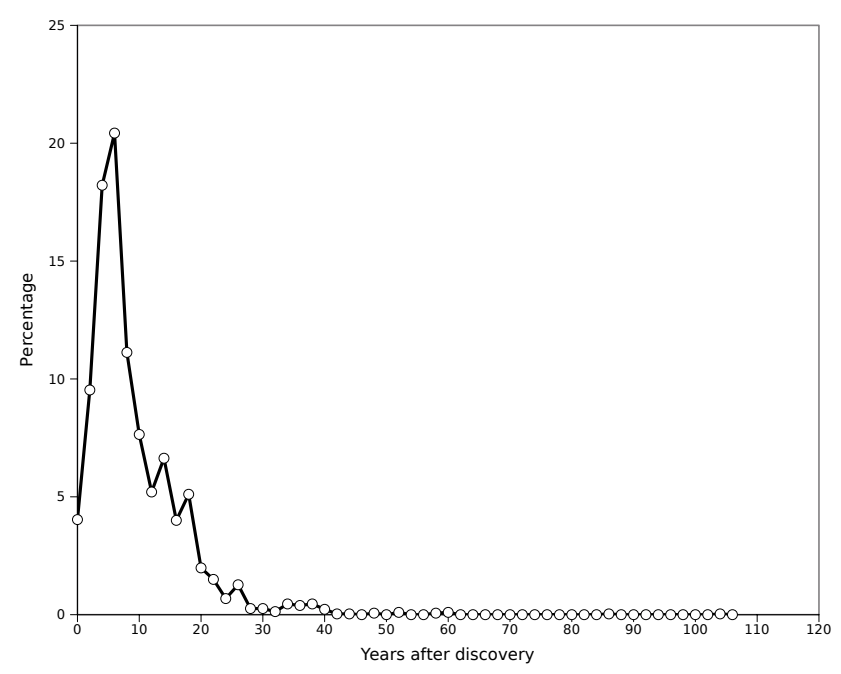

Fig. 12. Time lag between discovery and description of abyssal species. Data from P. Martinez.

of the species needed more than 10 years to become available (Fig. 12). By interpreting this figures one has to take into account that the 3074 species probably represent less that $5 \%$ of actual number of new species sampled in the abyss during this time. Many new species remain undescribed in natural history collections because of the lack of specialists. This is remarkably true for small macrobenthic and meiobenthic species. Megafaunal species and demersal fishes are relatively well known. From this dataset, almost $50 \%$ of the species were described before 1920 (Fig. 13). During the times of the First and the Second World Wars, taxonomical activities ceased almost completely. Then followed a golden era of abyssal taxonomy between 1960 and 1990 , when an additional $40 \%$ of the species were described. 


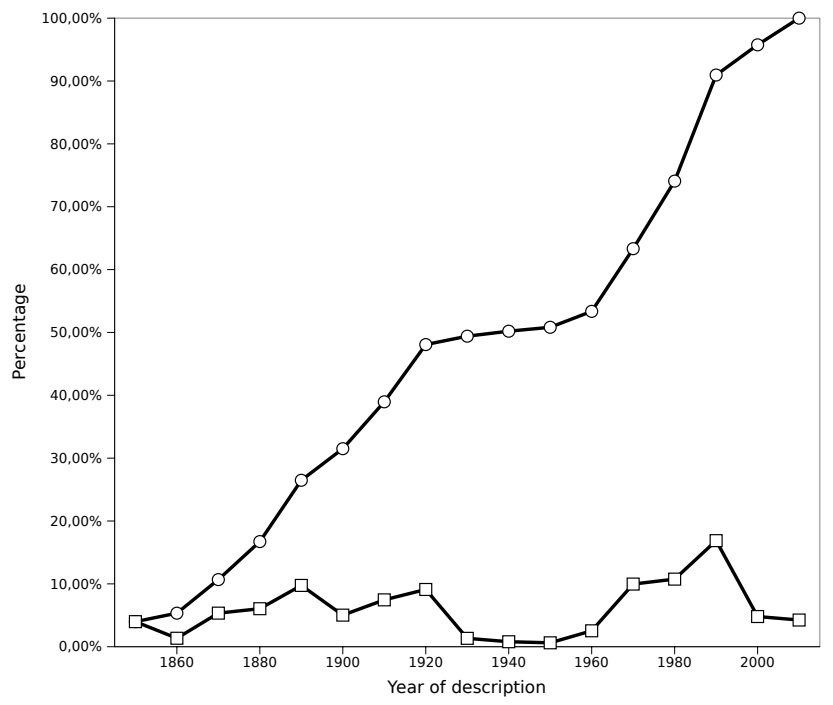

Fig. 13. Description rate of abyssal species during past 150 years. Upper curve: cumulative rate; lower curve: percentage of total per time unit. Data from P. Martinez.

After 1990, description rate declined, probably caused by the dramatic decrease of available taxonomic positions at universities in developed countries. Nevertheless, the number of descriptions of some animal groups has increased in recent years. Although isopod crustaceans from the abyss have been described for more than a century, most of the species have been described in the last 4 decades (Fig. 14). Several factors can explain this sudden high rate of descriptions. Firstly, during the last decade, deep-sea research and systematic sampling of the abyssal benthos has increased significantly. Furthermore, the usage of fine-meshed epibenthic sledges (Brenke, 2005) that collect macrofaunal animals such as isopods in very good condition allows for better systematic descriptions.

\section{General biogeography patterns}

\section{Global deep-sea provinces}

Analysis of samples from the Challenger expedition in the 19 th century and other early oceanographic cruises suggested the existence of heterogeneity in the distribution of animals across the deep-sea floor. Two paths of thought on the span of occurrence of species in the seafloor were developed in the 1950s: (1) cosmopolitan and widespread species distribution, caused by the lack of ecological barriers and relative homogeneity of conditions on the deep-sea floor; and (2) a trend with depth towards stenotopical fauna caused by topographic barriers. These patterns were revised and summarized by Vinogradova (1997).

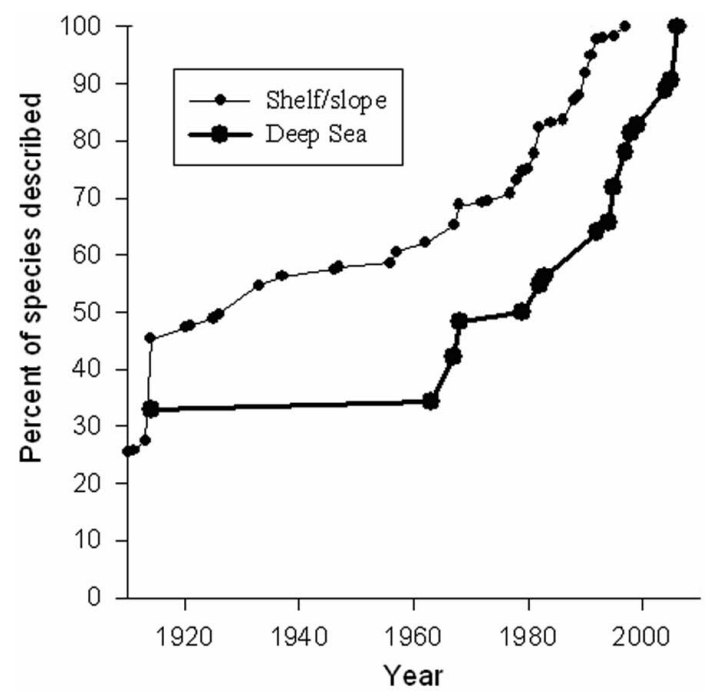

Fig. 14. Rate of new species descriptions in isopod crustaceans from the Antarctic shelf versus the abyss over the past 120 yr. Few species have been described from the deep sea to date, and most of them have been described in the last 4 decades (from Kaiser and Barnes, 2008).

A diversity of patterns, subdividing the deep-sea floor into faunal regions or provinces has been proposed in the deep-sea benthos literature since the 1970s. Most of these were supported by patterns of distribution of model faunal groups such as isopods (Wolff, 1970; Menzies et al., 1973; Kussakin, 1973), tunicates (Monniot, 1979), asteroids (Sibuet, 1979), bathyal brachiopods (Zezina, 1997) and molluscs in the Southern Ocean (Linse et al., 2006). Most of these patterns recognize that temperature and food supply are factors that define the distribution of specialized faunal groups. However, many biogeographic classifications for the deep-sea benthos are regional, based on available and limited datasets. Moreover, several deep-sea habitats have a high degree of species endemism. This has been summarised for deep-sea regions from the work done by Russian scientists for the abyssal fauna (Vinogradova, 1979), where the bipolar distribution in eurythermal species is recognised. Belyaev's regionalization of the ultra-abyssal and hadal ecosystems indicated that, although most trenches have been under-sampled, the available data show that over $50 \%$ of the species are endemic and over $90 \%$ occur only in one trench, and contributed the term "circular distributions" in his subdivision of the oceans (Belyaev, 1989). The classification of the Pacific seamounts by Parin et al. (1997) recognized faunistic differences for echinoids, shrimp, tanaids and fish species in seamounts and guyots with summits from 200 to $850 \mathrm{~m}$ and grouped these into geomorphologically distinct sub-areas. The degree of endemism and species relationships were explained by the relatively mountain-less abyssal area that serves as a biogeographic barrier. The biogeographic relationships among deep-sea hydrothermal vent 
faunas at a global scale have been described by Tunnicliffe et al. (1996, 1998), Van Dover et al. (2002), Shank (2004), Tyler et al. (2003), Bachraty et al. (2008) and Desbruyères et al. (2007) for back-arc basins. The abyssal fauna associated with ferromanganese nodules has been analyzed by Veillette et al. (2007).

More recently, the Global Open Ocean and Deep Seabed (GOODS, 2009) biogeographic classification divided the ocean beyond the continental shelf into separate uncoupled biogeographic pelagic and benthic provinces. This classification used a combined physiognomic (environmental features) and taxonomic (species composition when data were available) approach. As in previous biogeographic classifications, the provinces are a stationary picture, lacking seasonality. The pelagic zone was divided into 30 provinces based on the properties of water masses and currents. The benthic zone was subdivided into three large depth zones consisting of 37 provinces: 14 bathyal $(300-3500 \mathrm{~m}), 13$ abyssal (3500$6500 \mathrm{~m}$ ) and 10 hadal $(>6500 \mathrm{~m})$. In addition, 10 hydrothermal vent provinces were delineated (GOODS, 2009).

Early marine deep-sea biogeographic classifications have generalized boundaries that are not precise. Existing deep sea biogeographic classifications have been based on environmental variables (e.g. bathymetry, water masses and currents, substrate, nutrients, and oxygen levels), more than on biological information (e.g., known distribution of certain species). The grouping of processes and environmental variables where species may co-occur range in scales from broad-scale ecological provinces to finer scale classifications based predominantly on geomorphic units, such as the "seascapes" approach (Heap et al., 2009). Biogeographic classifications meet a basis for hypotheses and further scientific studies in topics of the origin and evolution of deep-sea faunal assemblages. The existing biogeographic classifications have helped to differentiate the broad species spatial distribution patterns, habitats, ecosystem processes (Spalding et al., 2007) and co-occurrence of species within them by using biological and environmental data to partition ecological units at a chosen scale (UNEP-WCMC, 2007). Scientific research in the deep ocean is expensive and time-consuming, and the analysis of the data collected presents complex challenges. Some of the challenges of developing and applying biogeographic classification include considering appropriate scales for analysis, the difficulties of selecting boundaries in a fluid marine environment, the improvement of underlying data and that of the scientific understanding of connectivity of deep-sea species in the ecosystem. There are major gaps in global coverage of data. Some regions and marginal seas have a database infrastructure that is inadequate to maintain as well as incomplete data sets and information. Substantial improvements will be required for future analyses. Improving data accessibility and interoperability is required so that future biogeographic analysis can be extended and integrated within and across regions. Information that will require a better resolution and knowledge includes distribution of the types of substratum (hard vs. soft), total sediment thickness and the composition of marine sediments. Substratum is important to the benthic biological community defining the species composition and spatial variability. The hard substrata are required for attachment of some sessile species. We know hardly anything on escarpments and other vertical topographic features because of the difficulty in sampling these ecosystems that have steep depth gradients. An integrative programme focused on human capacity to study and understand the oceans at global scale is required to build on international scientific cooperation. Given these sampling limitations, new species distribution modelling techniques and statistical methods have shown promise in the extrapolation of large-scale or global patterns of habitat suitability and potential distribution from existing deep-sea samples (Davies et al., 2008; Tittensor et al., 2009). The existing biogeographic classifications will evolve to more refined schemes as new information becomes available, as our understanding of metapopulation connectivity of deep-sea species improves and a better use of biological and environmental surrogates is acquired.

The applications of biogeographic classification to the conservation and sustainable use of the deep sea and biodiversity lie within the context of marine spatial planning. Current provinces recognized, in spite of the limited knowledge of the deep-sea fauna or poor coverage, can help delineate deep-sea management boundaries useful for the design of deep-sea marine protected areas and networks. Relatively little protection exists for the deep sea (e.g. the coverage of seamounts reaches $\sim 2 \%$ of the total protected). Therefore, developing conservation strategies based on robust biogeographic classifications will help protect deep-sea species vulnerable to degraded and fragmented seascapes or shifting habitats caused by climate change. Decision-making focused on proposals for marine development, resource exploitation, and investment projects will require the biogeographic knowledge as ocean services from the deep sea are recognized for human welfare.

\section{Human and climate driven changes in deep-sea ecosystems}

The inaccessibility of the deep sea has kept this ecosystem virtually unknown to most people for very long. As a result, natural or anthropogenic impacts in the deep sea are not recognised compared to similar-magnitude processes on land. With the depletion of resources in shallower waters, industries such as fisheries, hydrocarbon exploitation and marine mining are increasingly exploring deeper systems, with activities surpassing $2000 \mathrm{~m}$ depth (UNEP-WCMC, 2007). Recent studies have highlighted the vulnerability of deep-sea ecosystem functioning to biodiversity loss (Danovaro et al., 2008a). Understanding the present threats to deep-sea biodiversity is therefore crucial for a sustainable management 
of deep-sea ecosystems and their resources. In some instances, the impact of human activities on deep-sea ecosystems has been taken in account in recent years and monitoring has been put in place, at least partially, leading to management and conservation actions. This is the case, for example of some fisheries, hydrocarbon extraction and, more recently, mining. However, the impact of most other humanrelated activities such as litter accumulation, chemical pollution and, indirectly, climate change on deep-sea habitats and ecosystems remains unknown. One of the major limitations to developing robust conservation and management options is the relatively small amount of information available on deep-sea habitat distribution, faunal composition, biodiversity and ecosystem functioning (UNEP-WCMC, 2007). Strengthened international scientific coordination of efforts through global programmes such as the Census of Marine Life (www.coml.org) and collaborations with industry are helping to address these gaps to knowledge. A revision of past, present and future anthropogenic impacts on the deep sea and analysis of the effects in the habitats and fauna is being prepared based on available knowledge and scientific expert advice (SYNDEEP workshop; Ramirez-Llodra et al., 2010). The results of current and future investigations on deep-sea anthropogenic impacts will provide the scientific data needed by policy makers and conservation organisations. Some of the more critical human impacts to deep-sea ecosystems are briefly described below.

\subsection{Waste, litter and chemical dumping}

The argument for waste disposal to abyssal depths during the second half of the 20th century was based on the incorrect assumption that the deep sea was a monotonous and still environment with high assimilative capacity. Industrial and municipal wastes were dumped at $2500 \mathrm{~m}$ on the eastern coast of the USA (DWD106) between 1972 and 1992 (Thiel, 2003). Although monitoring was scarce, studies showed that the isotopic composition of the deep-sea echinoid Echinus affinis had been affected (Van Dover et al., 1992) and there had been faunal changes at the seabed (Bothner et al., 1994). Low level radioactive waste was also disposed in metal drums at abyssal depths in the NE Atlantic between 1949 and 1982 (Thiel, 2003). Although no effects from leakage have been reported, no studies were conducted directly in the area were the drums are found (Sibuet et al., 1985; Thiel, 2003). While disposal of these wastes ceased less than 3 decades ago, littering of the deep-sea floor with solid and chemical contaminants has continued to increase. The major sources of litter are coastal and riverine input and disposal from ships. Deep-sea litter includes mainly plastics, metal and glass, as well as discarded or lost fishing gear (longlines and nets), the last being a major issue in closed seas such as the Mediterranean. Trawling and ROV studies regularly collect and visualise litter accumulated on the deep seafloor, but its effects in the communities and habitat are mostly unknown. Potential effects include the suffocation of species and physical damage to sessile fauna such as corals or sponges, as well as ghost fishing from lost/discarded fishing gear. Present research programmes are addressing these issues, including the degradation of plastics into microplastics and their effect in the fauna. Chemical pollution is also being considered. A variety of chemical contaminants reach the marine system from atmospheric transportation, riverine input or direct input from industry, with recent evidence of accumulation in deep-sea sediments and fauna. These contaminants include persistent organic pollutants (POPs), radioelements and toxic metals (inter alia $\mathrm{Hg}, \mathrm{Cd}, \mathrm{Pb}, \mathrm{Ni}$, isotopic tracers), as well as pesticides, herbicides and pharmaceuticals. Little is known regarding chemical contamination of the deep sea, but recent pioneer studies have provided initial results. For example, significant levels of dioxins have been found in the deep-sea rose shrimp Aristeus antennatus, one of the main biological resources in the Mediterranean (Rotllant et al., 2006), and elevated levels of POPs have been reported from meso- and bathypelagic cephalopods (Unger et al., 2008). Evidence is also available for the accumulation of metallic contaminants such as mercury and lead in deep-sea sediments (Richter et al., 2009), with unknown effect on the fauna. Topography, such as the presence of canyons, and hydrography, including cascading events, play an important role in the distribution of contaminants in the deep-sea floor and need to be considered in future studies (Richter et al., 2009).

\subsection{Mineral resources}

Extractive industries that affect deep-sea ecosystems include (1) the oil and gas industry, which has been exploring and exploiting resources at increasingly deep waters (now down to $3000 \mathrm{~m}$ ) since the 1990s (DWL, 2005) and (2) novel potential deep-sea mining industries. The main potential impact of hydrocarbon exploitation is from chemical pollution from drill cuttings or accidental spills (UNEP-WCMC, 2007). Oil companies are sensitive to environmental disturbance and have strong environmental controls on their exploration and production, as well as expanding collaborations with the scientific community. However, major environemental disasters are still happening in the 21st century - in April 2010 an explotion in the Deepwater Horizon drilling rig in the Gulf of Mexico caused the largest accidental marine oil spill in the history of the petroleum industry. At the time of writing, the effects of the oil spill on the deep-sea habitats and fauna was unknown. Regarding mining, there are 3 major types of potentially economically viable deep-sea mineral resources: (1) polymetallic manganese nodules from abyssal plains, (2) cobalt-rich ferromanganese crusts from seamounts, and (3) massive sulphide deposits from hydrothermal vents. Manganese nodules contain a variety of minerals such as cobalt, copper, iron, lead, manganese, nickel and zinc, and pilot studies were developed in parallel with scientific understanding of deep-sea 
biodiversity and the effect of disturbance at the seabed (ISA, 2004). At present manganese nodule mining, regulated by the International Seabed Authority (ISA) is not considered economically feasible (UNEP-WCMC, 2007). Cobalt-rich ferromanganese crusts accumulate over rock on seamounts and active mountain chains and could provide up to $20 \%$ of the global cobalt demand, but their exploitation is not costeffective to date (Rona, 2003; UNEP-WCMC, 2007). At the time of writing, mining of massive sulphide deposits at hydrothermal vent sites is the most viable. These deposits contain copper, lead, zinc, silver and gold, barium, nickel and other trace metals (Baker and German, 2009). Pilot studies and environmental assessments are being conducted on the Exclusive Economic Zones (EEZ) of Papua New Guinea and New Zealand and the exploitation of the resources is highly likely to begin in the coming decade. Although industry is working closely together with the scientific community, the major issue facing these potential exploitations is the lack of knowledge on the surrounding environments. Very little is known regarding community composition at extinct vents, the levels of endemism, the growth and reproductive patterns of the fauna and larval dispersal and colonisation potential, making it very difficult, if not impossible, to evaluate impact of mining. A "Code for Environmental Management of Marine Mining" (IMMS, 2009) is being developed by the International Marine Minerals Society (IMMS), as well as the International Seabed Authority (ISA) guidelines for environmental baselines and monitoring programmes (ISA, 2004; Van Dover, 2007), but further and detailed scientific studies are essential to evaluate the potential recovery of disturbed sites.

\subsection{Biological resources}

Since the 1990s the most dramatic human impact on deepsea communities is associated with fishing. In the past 30 years, the catch per tow of the main deep-sea fish species has declined by up to $99 \%$ (Devine et al., 2006). Although fishing activity occurs down to only $1500 \mathrm{~m}$ (Clark et al., 2006; Paully et al., 2005), Bailey et al. (2009) have shown that its impact is found in excess of $3000 \mathrm{~m}$ depth. The main targeted species are orange roughy (Hoplostethus atlanticus), alfonsinos (Beryx decadactylus), grenadiers (some macrurids), oreos (Allocyttus niger) and different species of shrimp (Pauly et al., 2003). One of the major aspects to be considered is that many deep-sea fish species are long lived and late reproducers and thus slow at re-establishing overharvested populations. The second aspect of deep-sea fishing is impact on the seabed. Trawls dragged over the seabed are non-selective and there is ample visual evidence that the invertebrate by-catch can be extensive and that the seafloor is left barren. Of particular concern is where fishing occurs in areas of frame building corals such as Lophelia pertusa or giant calcareous gorgonians with very old ages. In such fragile and sessile systems, long line fishing can also have an impact where the weight for the line may be dragged through corals during recovery. Lastly, there is the accidental loss or abandonment of fishing gear such as trawls and long lines, that continue fishing passively (ghost fishing) on the seafloor. Regulation of fishing in national waters depends on each state. On the high seas, however, limitation of fishing depends on international agreement and enforcement is difficult, with nations not abiding by the rules and regions where regulation is non-existent (UNEP-WCMC, 2007). Nevertheless, the decline of certain species and destruction of habitat such as cold-water corals has led to the enforcement of protection rules in some regions, such as the protection of coral ecosystems on the Darwin Mounds in the NE Atlantic (De Santo and Jones, 2007) and the legal ban of driftnet fishing and benthic trawling below $1000 \mathrm{~m}$ depth for the whole of the Mediterranean (WWF/IUCN, 2004), that made the deep benthic Mediterranean the largest protected area in the world.

\subsection{Climate change and ocean acidification}

The future scenario of global climate change will affect all marine areas. Temperature change over the next 100 years is predicted to be between 1.4 and $5.8^{\circ} \mathrm{C}$ (IPCC, 2007). This will have considerable effects on the surface of the oceans, which will be transmitted to depth. As the deep sea is a heterotrophic system relying mainly on the downward flux of surface primary production and is often considered food limited, changes in quality and quantity of production in the euphotic zone may have profound effects on the deep-sea faunal communities (Smith et al., 2008). Recent evidence indicates an expansion of the least productive surface waters of the global ocean by $\sim 800000 \mathrm{~km}^{2}$ per year (Polovina et al., 2008) and future reduction in primary production over large areas of the tropical/subtropical ocean caused by increased stratification (Behrenfeld et al., 2006; Smith et al., 2008). Although little is known as to how biodiversity is being affected, some data on community changes is available. An example is the "Amperima event", which took place at $5000 \mathrm{~m}$ on the Porcupine Abyssal Plain (PAP, NE Atlantic) between 1994 and 1997, where a population explosion of the holothurian Amperima rosea has been documented and related to changes in reproductive output resulting from changes in the quality and quantity of phytodetrital flux from the surface (Billett et al., 2001; Wigham et al., 2003). In the Eastern Mediterranean, an extensive climate anomaly in the early 1990s modified the physico-chemical characteristics of the deep waters (Roether et al., 1996). The abrupt decrease in temperature (of about $0.4^{\circ} \mathrm{C}$ ) and modified physico-chemical conditions over 2 years caused a significant change in benthic nematode biodiversity, a decrease of the functional diversity and species evenness, and an increase in the similarity to colder deep-Atlantic fauna (Danovaro et al., 2001, 2004). Furthermore, the observed increase in food availability on the seafloor produced an increase in metazoan abundance 
(Danovaro et al., 2008; Lampadariou et al., 2009). Given the high vulnerability of deep-sea fauna to temporal and spatial variations in food availability (reviewed in Smith et al., 2008) and other environmental conditions, the progressive intensification of climate-driven episodic events, ocean stratification and the rates of deep-sea warming, deep-sea fauna can be expected to undergo significant changes in response to present climate change.

Future effects of climate change to physical oceanographic processes have been suggested also. For example, the warming of surface waters would cause serious alterations in water mass circulation and, most importantly, in deep-water formation, resulting in the deep sea eventually becoming anoxic. Climatologically-induced changes include also the variation in periodicity and intensity of episodic events such as deep-water cascading (Canals et al., 2006; Company et al., 2008), the abrupt change in the thermoaline conditions such as the Eastern Mediterranean transient (Danovaro et al., 2001, 2004), the release of methane gas from methane hydrates, normally kept "frozen" under very proscribed conditions with a positive feedback on global warming (Kenvelvoden, 1988) and an increase in the extension of pelagic and benthic OMZs (Stramma et al., 2008) caused by stratification of the upper ocean (Keeling et al., 2010). Models predict a decline in oxygen of $1-7 \%$ over the next century (Keeling et al., 2010). The effects of such environmental changes on the deep-sea fauna are mostly unknown, although some predictions include changes in community composition and structure, diversity loss, altered transfers of organic matter from the shelf to abyssal depths, altered migrations in the pelagic realm, changes in the bentho-pelagic coupling and in the global biogeochemical cycle.

Carbon dioxide build up in the atmosphere, which leads to global warming, will also cause an increase in dissolved $\mathrm{CO}_{2}$ in seawater, leading to a significant acidification of the oceans. Predictions suggest that surface $\mathrm{pH}$ will fall quite rapidly and the calcium carbonate compensation depth will rise in the water column. Increased acidification of the water column may result in the dissolution of the calcium carbonate skeletons of deep-water corals (Guinotte et al., 2006) as has been shown in an experimental study with Lopphelia pertusa (Maier et al., 2009) and in the shells of adult molluscs and echinoderms. There is already evidence that larvae with aragonite skeletons are severely affected by lowered $\mathrm{pH}$ (Kurihara, 2008). Smith et al. (2008) have outlined a scenario for the deep sea in a high $\mathrm{CO}_{2}$ world. Under presentday conditions $\left(\mathrm{CO}_{2}=385 \mathrm{ppm}\right)$ diatoms and large zooplankton dominate surface primary and secondary production and there is a relatively high downward flux of this material, with 0.5 to $2 \%$ of surface production reaching the deep-sea bed, at times forming a labile phytodetrital layer that gives rise to high sediment community oxygen consumption. By 2100 the $\mathrm{CO}_{2}$ levels are predicted to rise to $540 \mathrm{ppm}$. Under these conditions, surface plankton will be dominated by picoplankton and microzooplankton, the mixed depth layer will be shallower and $1 \%$ of surface production will reach the seabed, resulting in lower benthic biomass, abundance and smaller body size.

\section{Conclusions}

The largest environment on Earth, the deep sea, has a number of characteristics that make it deep, diverse and definitively different. Below, we summarise the top 10 reasons why the deep sea is a unique ecosystem, still mostly unknown and that needs detailed and focused exploration and investigation into the future using state-of-the art technology with large-scale international coordination of efforts (Snelgrove, 2010). Increasing anthropogenic pressure in deep-sea habitats demands detailed scientific information from which to develop management and conservation efforts (Levin and Dayton, 2009).

\subsection{Top 10 characteristics that make the deep sea unique}

1. The deep-sea is the largest environment on Earth but one of the least studied. It includes a variety of unique habitats, with a large number of discoveries in the last 50 years. The global area covered by many of these habitats is still largely unknown and the proportion investigated is minimal. Hadal regions ( $>6000$ to $11000 \mathrm{~m}$ ) remain the least studied of all deep-sea environments.

2. The lack of photosynthetically-usable sunlight below $200 \mathrm{~m}$ results in a lack of primary production in most deep-sea ecosystems (Gage and Tyler, 1991). Exceptions include reducing deep-sea habitats (e.g. hydrothermal vents and cold seeps) where chemosynthetic microorganisms play the role of primary producers, with net gain of organic carbon (Jannasch, 1995).

3. Deep-sea benthic communities are amongst the most food-limited on the globe (Smith et al., 2008), yielding low faunal biomass and productivity (Rex et al., 2006; Rowe et al., 2008), except in chemosynthetically-driven ecosystems and beneath upwelling regions.

4. Deep-sea diversity is among the highest on Earth (Hessler and Sanders, 1967; Snelgrove and Smith, 2002), with a unimodal diversity-depth pattern (Rex et al., 1981, 1993), a poleward trend of decreasing diversity, and high evenness (Gage and Tyler, 1991; Flach and de Bruin, 1999) except in habitats where "extreme" environmental factors (e.g. vents, seeps, OMZs) force high dominance of a few specially-adapted species.

5. Characteristic deep-sea communities are distinct from shallow-water fauna. Although no invertebrate phyla 
are exclusive to deep-sea ecosystems, at lower taxonomic levels several otherwise rare groups of animals and abundant large protozoans dominate biomass, energy flow and biodiversity patterns in deep-sea sediments.

6. The interconnected nature of the deep sea, the small sampling coverage achieved to date and the paucity of species descriptions from even those collections make taxonomic coordination particularly difficult but especially important in understanding large-scale (regional and global) diversity patterns (Mora et al., 2008).

7. Many deep-sea species show either gigantism (amphipods, isopods, pycnogonids, some holothurians such as Psychropotes longicauda, xenophyophores) or dwarfism (nematodes, protobranch bivalves and many other taxa). In both cases, the main mechanism invoked is an adaptation to the decrease in food availability with depth.

8. Although some areas of the deep sea remain uncontaminated, there is an increasing impact of human activities on deep-sea habitats and communities, related to the decrease of natural and mineral resources on land and in shallow waters and coupled to technological advances.

9. The effects of anthropogenic impacts on deep-sea habitats and communities are still mostly unknown and difficult to predict because of the many rare species, special habitats and often slow growth and delayed maturity of deep-water species. Ecosystem services provided by the deep sea are in their infancy but will increase with technological development.

10. Management and conservation of deep-sea ecosystems is often complex and under-developed because of the lack of scientific knowledge as well as the remoteness of the habitats, the majority of which are found in international waters.

Acknowledgements. This paper has been written under the umbrella of the Census of Marine Life synthesis initiative SYNDEEP, supported by the Alfred P. Sloan Foundation, Fondation Total and EuroCoML, which are gratefully acknowledged. ERLL is funded by the CoML-ChEss programme (A. P. Sloan Foundation) and Fondation Total. CRG acknowledges support from the CoMLChEss programme. LAL acknowledges support from the National Science Foundation and the CoML-COMARGE and ChEss programmes. DPT acknowledges funding from the CoML-FMAP programme. MV acknowledges the CoML-MAR-ECO programme (Sloan Foundation and NOAA). H. Hafermann and R. Mahatma analysed the samples used for Fig. 12. The authors would like to thank the editorial comments of Gerhard Herndl and the reviews from D. Pawson and J. Ott, which helped improved the orignial manuscript.

Edited by: G. Herndl

\section{References}

Albaina, A. and Irigoien, X.: Zooplankton communities and oceanographic structures in a high-resolution grid in the southeastern corner of the Bay of Biscay, Estuar. Coast. Shelf Sci., 75, 433-446, 2007.

Allen, J. A. and Sanders, H. L.: The zoogeography and diversity of the deep-sea protobranch bivalves of the Atlantic: the epilogue, Prog. Oceanogr., 38, 95-153, 1996.

Amano, K., Little, C. T. S., and Inoue, K.: A new Miocene whalefall community from Japan, Palaeogeogr. Palaeoecol., 247, 236242, 2007.

Álverez-Pérez, G., Busquets, P., De Mol, B., Sandoval, N. G., Canals, M., and Casamor, J. L.: Deep-water coral occurrences in the Strait of Gibraltar, in: Cold-water Corals and Ecosystems, edited by: Freiwald, A. and Roberts, M., Springer-Verlag, Berlin, Heidelberg, 207-221, 2005.

AMAP Assessment Report: Arctic Pollution Issues, Arctic Monitoring and Assessment Programme (AMAP), Oslo, 859 pp., 1998.

Angel, M. V.: The pelagic environment of the open ocean, in: Ecosystems of the World, Vol. 28 Ecosystems of the Deep Ocean, edited by: Tyler, P. A., Elsevier, Amsterdam, 39-80, 2003.

Arístegui, J., Gasol, J. M., Duarte, C. M., and Herndl, G. J.: Microbial oceanography of the dark ocean's pelagic realm, Limnol. Oceanogr., 54, 1501-1529, 2009.

Arrigo, K. R., van Dijken, G. L., Ainley, D. G., Fahnestock, M. A., and Markus, T.: Ecological impact of a large Antarctic iceberg, Geophys. Res. Lett., 29, 1104, doi:10.1029/2001GL014160 , 2002.

Asper, V. L., Deuser, W. G., Knauer, G. A., and Lohrenz, E.: Rapid coupling of sinking particle fluxes between surface and deep ocean waters, Nature, 357, 670-672, 1992.

Baba, K., Macpherson, E., Poore, G. C. B., Ahyong, S. T., Bermudez, A., Cabezas, P., Lin, C.-W., Nizinski, M., Rodrigues, C., and Schnabel, K. E.: Catalogue of squat lobsters of the world (Crustacea: Decapoda: Anomura - families Chirostylidae, Galatheidae and Kiwaidae), Zootaxa, 1905, 1-220, 2008.

Bachraty, C., Legendre, P., and Desbruyères, D.: Biogeographic relationships among deep-sea hydrothermal vent faunas at global scale, Deep-Sea Res. Pt. I, 56, 1371-1378, 2009.

Baguley, J. G., Montagna, P. A., Lee, W., Hyde, L. J., and Rowe, G. T.: Spatial and bathymetric trends in Harpacticoida (Copepoda) community structure in the northern Gulf of Mexico deep-sea, J. Exp. Mar. Biol. Ecol., 330, 327-341, 2006.

Bailey, D. M., Collins, M. A., Gordon, J. D. M., Zuur, A. F., and Priede, I. G.: Long-term changes in deep-water fish populations in the northeast Atlantic: a deeper reaching effect of fisheries?, P. Roy. Soc. B., 276, 1965-1969, 2009.

Baker, E. T. and German, C. R.: On the global distribution of midocean ridge hydrothermal vent-fields, in: The Thermal Structure of the Oceanic Crust and the Dynamics of Seafloor Hydrothermal Circulation, Geoph. Monog. Series, 148, 245-266, 2004.

Baker, M. C. and German, C. R.: Going for gold! Who will win in the race to exploit ores from the deep sea?, Ocean Challenge, 16, 10-17, 2009.

Baker, M. C., Ramirez-Llodra, E., Tyler, P. A., German, C. R., Boetius, A., Cordes, E., Dubilier, N., Fisher, C., Levin, L. A., Metaxas, A., Rowden, A., Santos, R. S., Shank, T. M., Van Dover, C. L., Young, C. M., and Warén, A.: Biogeography, 
Ecology and Vulnerability of Chemosynthetic Ecosystems in the Deep Sea, in: Life in the World's Oceans: Diversity, Distribution, and Abundance, edited by: McIntyre, A., Chapter 9, Wiley Blackwell, Oxford, 161-183, 2010a.

Baker, M. C., Ramirez-Llodra, E., and Perry, D.: ChEssBase: an online information system on species distribution from deep-sea chemosynthetic ecosystems, Version 3, World Wide Web electronic publications, www.noc.soton.ac.uk/chess/db_home.php, last access: 8 June 2010, 2010b.

Ballard, R.: The History of Woods Hole's Deep Submergence Program, 50 Years of Ocean Discovery, 67-84, 2000.

Beaulieu, S. E. and Smith, K. L. J.: Phytodetritus entering the benthic boundary layer ad aggregated on the sea floor in the abyssal NE Pacific: macro- and microscopic composition, Deep-Sea Res. Pt. II, 45, 781-815, 1998.

Beebe, W.: Half Mile Dow, edited by: Lane, J., The Bodley Head, London, 344 pp., 1939.

Behrenfeld, M. J., O’Malley, R. T., Siegel, D. A., McClain, C. R., Sarmiento, J. L., Feldman, G. C., Milligan, A. J., Falkowski, P., Letelier, R. M., and Boss, E. S.: Climate-driven trends in contemporary ocean productivity, Nature, 444, 753-755, 2006.

Belyaev, G. M.: Deep-Sea Ocean Trenches and Their Fauna, Nauka Publishing House, Moscow, 385, Translated to English by Scripps Institution of Oceanography, USA, 1989 pp., 2004.

Bergquist, D. C., Williams, F. M., and Fisher, C. R.: Longevity record for deep sea invertebrate, Nature, 403, 499, 2000.

Bergstad, O. A., Falkenhaug, T., Astthorsson, O., Byrkjedal, I., Gebruk, A. V., Piatkowski, U., Priede, I. G., Santos, R. S., Vecchione, M., Lorance, P., and Gordon, J. D. M.: Towards improved understanding of the diversity and abundance patterns of the mid-ocean ridge macro- and megafauna, Deep-Sea Res. Pt. II, 55, 1-5, 2008.

Bett, B. J.: UK Atlantic Margin Environmental Survey: Introduction and overview of bathyal ecology, Cont. Shelf Res., 21, 917956, 2001.

Billett, D. S., Lampitt, R. S., Rice, A. L., and Mantoura, R. F. C.: Seasonal sedimentation of phytoplankton to the deep-sea benthos, Nature, 302, 520-522, 1983.

Billett, D. S. M., Bett, B. J., Rice, A. L., Thurston, M. H., Galéron, J., Sibuet, M., and Wolff, G. A.: Long-terms change in the megabenthos of the Porcupine Abyssal Plain, Prog. Oceanogr., 50, 325-348, 2001.

Blankenship, L. E. and Levin, L. A.: Extreme food webs: Foraging strategies and diets of scavenging amphipods from the ocean's deepest 5 kilometers, Limnol. Oceanogr., 52, 1685-1697, 2007.

Blankenship-Williams Lesley, E. and Levin, L. A.: Living Deep: a synopsis of hadal trench ecology, Mar. Technol. Soc. J., 43, 137-143, 2009.

Blankenship, L., Yayanos, A., Cadien, D., and Levin, L.: Vertical zonation patterns of scavenging amphipods from the Hadal zone of the Tonga and Kermadec trenches, Deep-Sea Res., 53, 48-61, 2006.

Boucher, G. and Lambshead, P. J. D.: Marine nematode ecological biodiversity in samples from temperate, tropical and deep-sea regions, Conserv. Biol., 9, 1594-1604, 1995.

Bouchet, P.: The magnitude of marine biodiversity, in: The exploration of Marine Biodiversity - Scientific and Technological Challenges, edited by: Duarte, C. M., Fundación BBVA, Bilbao, 31-64, 2006.
Brandt, A. and Ebbe, B.: ANDEEP III ANtarctic benthic DEEPsea biodiversity: colonisation history and recent community patterns, Deep-Sea Res. Pt. II, 54, 1645-1904, 2007.

Brandt, A., De Broyer, C., Gooday, A. J., Hilbig, B., and Thomson, M. R. A.: Introduction to ANDEEP (Antarctic benthic DEEPsea biodiversity: colonization history and recent community patterns) - a tribute to Howard L. Sanders, Deep-Sea Res. Pt. II, 51, 1457-1465, 2004a.

Brandt, A., Brökeland, W., Brix, S., and Malyutina, M.: Diversity of Southern Ocean deep-sea Isopoda (Crustacea, Malacostraca) - a comparison with shelf data, Deep-Sea Res. Pt. II, 51, 17531768, 2004b.

Brandt, A., Brix, S., Brökeland, W., Choudhury, M., Kaiser, S., and Malyutina, M.: Deep-sea isopod biodiversity, abundance, and endemism in the Atlantic sector of the Southern Ocean - Results from the ANDEEP I-III expeditions, Deep-Sea Res. Pt. II, 54, 1760-1775, 2007a.

Brandt, A., De Broyer, C., De Mesel, I., Ellingsen, K. E., Gooday, A., Hilbig, B., Linse, K., Thomson, M., and Tyler, P.: The deep benthos, London, Philos. T. Roy. Soc. B, 362, 39-66, $2007 \mathrm{~b}$.

Brandt, A., Gooday, A. J., Brandao, S. N., Brix, S., Brökeland, W., Cedhagen, T., Choudhury, M., Cornelius, N., Danis, B., De Mesel, I., Diaz, R. J., Gillan, D. C., Ebbe, B., Howe, J. A., Janussen, D., Kaiser, S., Linse, K., Malyutina, M., Pawlowski, J., Raupach, M., and Vanreusel, A.: First insights into the biodiversity and biogeography of the Southern Ocean deep sea, Nature, 447, 307-311, 2007c.

Brenke, N.: An epibenthic sledge for operations on marine soft bottom and bedrock, Mar. Technol. Soc. J., 39, 10-19, 2005.

Broch, H.: Riffkorallen im Nordmeer einst und jetzt, Naturwissenschaften, 37, 1-3, 1922.

Bothner, M. H., Takada, H., Knight, I. T., Hill, R. T., Butman, B., Farrington, J. W., Colwell, R. R., and Grassle, J. F.: Sewage contamination in sediments beneath a deep-ocean dump site off New York, Mar. Environ. Res., 38, 43-59, 1994.

Brüning, M., Sahling, H., MacDonald, I. R., Ding, F., and Bohrmann, G.: Origin, distribution, and alteration of asphalts at Chapopote Knoll, Southern Gulf of Mexico, Mar. Petrol. Geol., 27, 1093-1106, 2010.

Bucklin, A., Nishida, S., Schnack-Schiel, S., Wiebe, P. H., Lindsay, D., Machida, R. J., and Copley, N. J.: A Census of Zooplankton of the Global Ocean, in: Life in the World's Oceans: Diversity, Distribution, and Abundance, edited by: McIntyre, A., Chapter 13, Wiley Blackwell, Oxford, 247-265, 2010.

Buesseler, K. O., Lamborg, C. H., Boyd, P. W., Lam, P. J., Trull, T. W., Bidigare, R. R., Bishop, J. K. B., Casciotti, K. L., Dehairs, F., Elskens, M., Honda, M., Karl, D. M., Siegel, D. A., Silver, M. W., Steinberg, D. K., Valdes, J., Van Mooy, B., and Wilson, S.: Revisiting Carbon Flux Through the Ocean's Twilight Zone, Science, 316, 567-570, 2007.

Buhl-Mortensen, L. and Mortensen, P. B.: Distribution and diversity of species associated with deep-sea gorgonian corals off Atlantic Canada, in: Cold-water Corals and Ecosystems, edited by: Freiwald, A. and Roberts, J. M., Springer-Verlag, Berlin, Heidelberg, 849-879, 2005.

Buhl-Mortensen, P., Buhl-Mortensen, L., Dolan, M., Dannheim, J., and Kröger, K.: Megafaunal diversity associated with marine landscapes of northern Norway: a preliminary assessment, Norw. J. Geol., 89, 163-171, 2009. 
Buhl-Mortensen, L., Vanreusel, A., Gooday, A. J., Levin, L. A., Priede, I. G., Buhl-Mortensen, P., Gheerardyn, H., King, N. J., and Raes, M.; Biological structures as a source of habitat heterogeneity and biodiversity on the deep ocean margins, Mar. Ecol., 31, 21-51, 2010.

Burdon-Jones, C. and Tambs-Lyche, H.: Observations on the fauna of the North Brattholmen stone-coral reef near Bergen, Årbok for Universitetet i Bergen, Matematisk-naturvitenskaplig Serie, 4, 1-24, 1960.

Challenger Report: Narrative of the cruise of H.M.S. Challenger, with a general account of the scientific results of the expedition, edited by: Tizard, T. H., Moseley, H. N., Buchanan, J. Y., and Murray, J., Partly Illustrated by WILD, J. J., Her Majesty’s Stationery Office, 1110 pp., 1885.

Cairns, S. D.: The deep-water Scleractinia of the Caribbean Sea and adjacent waters, Studies on the Fauna of Curaçao and other Caribbean Islands, 56, 1-341, 1979.

Canals, M., Puig, P., Durieu de Madron, X., Heussner, S., Palanques, A., and Fabres, J.: Flushing submarine canyons, Nature, 444, 354-357, 2006.

Carney, R. S.: Consideration of the oasis analogy for chemosynthetic communities at the Gulf of Mexico hydrocarbon vents, Geo-Mar. Lett., 149-159, 1994.

Cary, S. C. and Giovannoni, S. J.: Transovarial inheritance of endosymbiotic bacteria in clams inhabiting deep-sea hydrothermal vents and cold seeps, P. Natl. Acad. Sci., 90, 5695-5699, 1993.

Cavanaugh, C. M., McKiness, Z. P., Newton, I. L. G., and Stewart, F. J.: Marine chemosynthetic symbioses, in: The Prokaryotes, edited by: Dworkin, M., Falkow, S. I., Rosenberg, E., Schleifer, K.-H., and Stackebrandt, E., Springer, New York, 475507, 2006

Chhibber, H. L.: The Geology of Burma, Ch. VI Mud Volcanoes, Macmillan, New York, 79-85 pp., 1934.

Clark, M. R., Tittensor, D., Rogers, A. D., Brewin, P., Shclacher, T., Rowden, A., Stocks, K., and Consalvey, M.: Seamounts, deepsea corals and fisheries: vulnerability of deep-sea corals to fishing on seamounts beyond areas of national jurisdiction, UNEPWCMC, Cambridge, UK, 2006.

Clarke, A.: The polar deep seas, in: Ecosystems of the World (Vol. 28) - Ecosystems of the Deep Ocean, edited by: Tyler, P. A., Elsevier, Amsterdam, 239-260, 2003.

Clarke, A. and Johnston, N. M.: Antarctic marine benthic diversity, An Annual Review, Oceanogr. Mar. Biol., 41, 47-114, 2003.

Clough, L. M., Ambrose, J. W. G., Kirk Cochran, J., Barnes, C., Renaud, P. E., and Aller, R. C.: Infaunal density, biomass and bioturbation in the sediments of the Arctic Ocean, Deep-Sea Res. Pt. II, 44, 1683-1704, 1997.

Coleman, F. C. and Williams, S. L.: Overexploiting marine ecosystem engineers: potential consequences for biodiversity, Trends Ecol. Evol., 17, 40-44, 2002.

Colman, J. G., Gordon, D. M., Lane, A. P., Forde, M. J., and Fitzpatrick, J. J.: Carbonate mounds off Mauritania, Northwest Africa: status of deep-water corals and implications for management of fishing and oil exploration activities, in: Cold-water Corals and Ecosystems, edited by: Freiwald, A. and Roberts, M., Berlin, Heidelberg, Springer-Verlag, 417-441, 2005.

Company, J. B., Puig, P., Sardà, F., Palanques, A., Latasa, M., and Scharek, R.: Climate influence on deep sea populations, PLOS ONE, e1431, 1-8, 2008.
Consalvey, M., Clark, M. C., Rowden, A. A., and Stocks, K. I.: Life on seamounts, in: Life in the World's Oceans: Diversity, Distribution, and Abundance, edited by: McIntyre, A., Chapter 7 , Wiley Blackwell, Oxford, 123-139, 2010.

Cordes, E. E., Ribeiro da Cunha, M., Galéron, J., Mora, C., Olu-Le Roy, K., Sibuet, M., Van Gaever, S., Vanreusel, A., and Levin, L. A.: The influence of geological, geochemical, and biogenic habitat heterogeneity on seep biodiversity, Mar. Ecol., 31, 5161, doi:10.1111/j.1439-0485.2009.00334.x, 2009.

Cordes, E. E., Bergquist, D. C., Shea, K., and Fisher, C. R.: Hydrogen sulphide demand of long-lived vestimentiferan tube worm aggregations modifies the chemical environment at deep-sea hydrocarbon seeps, Ecol. Lett., 6, 212-219, 2003.

Cordes, E. E., Bergquist, D. C., Redding, M. L., and Fisher, C. R.: Patterns of growth in cold-seep vestimenferans including Seepiophila jonesi: a second species of long-lived tubeworm, Mar. Ecol., 28, 160-168, 2007.

Cordes, E. E., McGinley, M. P., Podowski, E. L., Becker, E. L., Lessard-Pilon, S., Viada, S. T., and Fisher, C. R.: Coral communities of the deep Gulf of Mexico, Deep-Sea Res. Pt. I, 55, 777-787, 2008.

Corliss, J. B., Dymond, J., Gordon, L. I., Edmond, J. M., von Herzen, R. P., Ballard, R. D., Green, K., Williams, D., Bainbridge, A., Crane, K., and van Andel, T. H.: Submarine thermal springs on the Galapagos Rift, Science, 203, 1073-1083, 1979.

Cosson, N., Sibuet, M., and Galéron, J.: Community structure and spatial heterogeneity of the deep-sea macrofauna at three constrating stations in the tropical northeast Atlantic, Deep-Sea Res. Pt. I, 44, 247-269, 1997.

Cosson-Sarradin, N., Sibuet, M., Paterson, G. L. J., and Vangriesheim, A.: Polychaete diversity at tropical deep-sea sites: Environmental effects, Mar. Ecol.-Prog. Ser., 165, 173-185, 1998.

Coull, B. C.: Species diversity and faunal affinities of meiobenthic copepoda in the deep sea, Mar. Biol., 14, 48-51, 1979.

Culver, S. J. and Buzas, M. A.: Global latitudinal species diversity gradient in deep-sea benthic foraminifera, Deep-Sea Res. Pt. I, 47, 259-275, 2000.

Dana, J. D.: Manual of Geology, Philadelphia, 798 pp., 1863.

Danovaro, R., Dell'Anno, A., Fabiano, M., Pusceddu, A., and Tselepides, A.: Deep-sea ecosystem response to climate changes: the eastern Mediterranean case study, Trends Ecol. Evol., 16, 505-510, 2001.

Danovaro, R., Gambi, C., and Della Croce, N.: Meiofauna hotspot in the Atacama Trench, eastern South Pacific Ocean, Deep-Sea Res. Pt. I, 49, 843-857, 2002.

Danovaro, R., Della Croce, N., Dell'Anno, A., and Pusceddu, A.: Depocenter of organic matter at $7800 \mathrm{~m}$ depth in the SE Pacific Ocean, Deep-Sea Res. Pt. I, 50, 1411-1420, 2003.

Danovaro, R., Pusceddu, A., and Dell'Anno, A.: Biodiversity response to climate change in a warm deep sea, Ecol. Lett., 7, 821828, 2004.

Danovaro, R., Gambi, C., Dell'Anno, A., Corinaldesi, C., Fraschetti, S., Vanreusel, A., Vincx, M., and Gooday, A. J.: Exponential decline of deep-sea ecosystem functioning linked to benthic biodiversity loss, Curr. Biol., 18, 1-8, 2008a.

Danovaro, R., Gambi, C., Lampadariou, N., and Tselepides, A.: Deep-sea biodiversity in the Mediterranean Basin: Testing for longitudinal, bathymetric and energetic gradients, Ecography, 
31, 231-244, 2008b.

Danovaro, R., Canals, M., Gambi, C., Heussner, S., Lampadariou, N., and Vanreusel, A.: Exploring Benthic Biodiversity Patterns and Hot Spots on European Margin Slopes, Oceanography, 22, 22-31, 2009.

Danovaro, R., Company, J. B., Corinaldesi, C., D’Onghia, G., Galil, B., Gambi, C., Gooday, A. J., Lampadariou, N., Luna, G. M., Morigi, C., Olu, K., Polymenakou, P., Ramirez-Llodra, E., Sabbatini, A., Sardà, F., Sibuet, M., and Tselepides, A.: Deep-Sea biodiversity in the Mediterranean Sea: the known, the unknown and the unknowable, PLOS ONE, 5, e11832, 2010.

Davies, A. J., Wisshak, M., Orr, J. C., and Roberts, J. M.: Predicting suitable habitat for the cold-water coral Lophelia pertusa (Scleractinia), Deep-Sea Res. Pt. I, 55, 1048-1062, 2008.

Davies, A. J., Duineveld, G. C. A., van Weering, T. C. E., Mienis, F., Quattrini, A. M., Seim, H. E., Bane, J. M., and Ross, S. W.: Short-term environmental variability in cold-water coral habitat at Viosca Knoll, Gulf of Mexico, Deep-Sea Res. Pt. I, 57, 199212, 2010.

De Mesel, I., Lee, H. J., Vanhove, S., Vincx, M., and Vanreusel, A.: Species diversity and distribution within the dee-sea nematode genus Acantholaimus on the continental shelf and slope in Antarctica, Polar Biol., 29, 860-871, 2006.

De Mol, B., Van Rensbergen, P., Pillen, S., Van Herreweghe, K., Van Rooij, D., McDonnell, A., Huvenne, V., Ivanov, M., Swennen, R., and Henriet, J. P.: Large deep-water coral banks in the Porcupine Basin, southwest of Ireland, Mar. Geol., 188, 193231, 2002.

De Mol, B., Kozachenko, M., Wheeler, A., Alvares, H., Henriet, J.P., and Olu-Le Roy, K.: Thérèse Mound: a case study of coral bank development in the Belgica Mound Province, Porcupine Seabight, Int. J. Earth Sci., 96, 103-120, 2007.

De Santo, E. and Jones, P. J. S.: Offshore marine conservation policies in the North East Atlantic: emerging tensions and opportunities, Mar. Policy, 31, 336-347, 2007.

Desbruyerès, D., Segonzac, M., and Bright, M.: Handbook of deepsea hydrothermal vent fauna, Second completely revised edition, Linz, Denisia, 18, 544 pp., 2006.

Desbruyères, D., Hashimoto, J., and Fabri, M.-C.: Composition and Biogeography of Hydrothermal Vent Communities in Western Pacific Back-Arc Basins, Geoph. Monog. Series, 166, 215-234, 2007.

Devine, J. A., Baker, K. D., and Haedrich, R. L.: Deep-sea fishes qualify as endangered, Nature, 439, 336-347, 2006.

Dinet, A. and Vivier, M.-H.: Le meiobenthos abyssal du Golfe de Gascogne I.I. Les peuplements de nématodes et leur diversité spécifique, Cah. Boil. Mar., 20, 109-123, 1979.

Ding, F., Spiess, V., Brüning, M., Fekete, N., Keil, H., and Bohrmann, G.: A conceptual model for hydrocarbon accumulation and seepage processes around Chapopote asphalt site, southern Gulf of Mexico: from high resolution seismic point of view, J. Geophys. Res., 113, B08404, doi:10.1029/2007JB005484, 2008.

Dorschel, B., Wheeler, A. J., Huvenne, V. A. I., and de Haas, H.: Cold-water coral mounds in an erosive environmental setting: TOBI side-scan sonar data and ROV video footage from the northwest Porcupine Bank, NE Atlantic, Mar. Geol., 264, 218$229,2009$.
D’Onghia, G., Maiorano, P., Sion, L., Giove, A., Capezzuto, F., Carlucci, R., and Tursi, A.: Effects of deep-water coral banks on the abundance and size structure of the megafauna in the Mediterranean Sea, Deep Sea Res. Pt. II, 57, 397-411, 2010.

Dons, C.: Norges korallrev, Det Kongelige Norske Videnskabers Selskabs Forhandlinger, 16, 37-82, 1944.

Dower, J. F. and Brodeur, R. D.: The role of biophysical coupling in concentrating marine organisms around shallow topographies, J. Mar. Syst., 50, 1-2, 2004.

Dubilier, N., Bergin, C., and Lott, C.: Symbiotic diversity in marine animals: the art of harnessing chemosynthesis, Nat. Rev. Microbiol., 6, 725-740, 2008.

Duineveld, G. C. A., Lavaleye, M. S. S., and Berghuis, E. M.: Particle flux and food supply to a seamount cold-water coral community (Galicia Bank, NW Spain), Mar. Ecol.-Prog. Ser., 277, 13-23, 2004.

DWL, Douglas Westwood Ltd.: Marine industries global market analyses, Marine Foresight Series 1, Marine Institute, Ireland, 2005.

Durrieu de Madron, X., Nyffeler, F., Monaco, A., and Casamor, J. L.: Circulation and dynamics of suspended particulate matter, in: EUROMARGE-NB Final Report, edited by: Canals, M., Casamor, J. L., Cacho, I., Calafat, A. M., and Monaco, A., MAST II Programme, EC, 13-39, 1996.

Ebbe, B., Billett, D. S. M., Brandt, A., Ellingsen, K., Glover, A., Keller, S., Malyutina, M., Martínez Arbizu, P., Molodtsowa, T., Rex, M., Smith, C., and Tselepides, A.: Diversity of Abyssal Marine Life, in: Life in the World's Oceans: Diversity, Distribution, and Abundance, edited by: McIntyre, A., Chapter 8, Wiley Blackwell, Oxford, 139-160, 2010.

Ellingsen, K. E. and Gray, J. S.: Spatial patterns of benthic diversity: is there a latitudinal gradient along the Norwegian continental shelf?, J. Anim. Ecol., 71, 373-389, 2002.

Etnoyer, P. and Morgan, L.: Habitat-forming deep-sea corals in the Northeast Pacific Ocean, in: Cold-Water Corals and Ecosystems: Erlangen Earth Conference Series, edited by: Freiwald, A. and Roberts, J. M., Springer, Berlin, Heidelberg, 331-343, 2005.

Etter, R. J. and Rex, M. A.: Population differentiation decreases with depth in deep-sea gastropods, Deep-Sea Res. Pt. I, 37, 1251-1261, 1990.

Etter, R. J. and Grassle, J. F.: Patterns of species diversity in the deep-sea as a function of sediment particle size diversity, Nature, 360, 576-578, 1992.

Etter, R. J. and Mullineaux, L. S.: Deep-Sea Communities, in: Marine Community Ecology, edited by: Bertness, M. D., Gaines, S. D., and Hay, M. E., Sinauer Associates, Inc., Sunderlands, Massachusetts, 367-393, 2001.

Flach, E. and de Bruin, W.: Diversity patterns in macrobenthos across a continental slope in the NE Atlantic, J. Sea Res., 42, 303-323, 1999.

Flexas, M. M., Boyer, D. L., Espino, M., Puigdefàbregas, J., Rubio, A., and Company, J. B.: Circulation over a submarine canyon in the NW Mediterranean, J. Geophys. Res., 113, C12002, doi:10.1029/2006JC003998, 2008.

Fock, H. O., Matthiessen, B., Zidowitz, H., and Von Westernhagen, H.: Diel and habitat-dependent resource utilisation by deep-sea fishes at the Great Meteor seamount: niche overlap and support for the sound scattering layer interception hypothesis, Mar. Ecol.-Prog. Ser., 244, 219-233, 2002. 
Fonseca, G. F. C. and Soltwedel, T.: Deep-sea meiobenthic communities underneath the mariginal ice zone off Eastern Greenland, Polar Biol., 30, 607-618, 2007.

Forbes, E.: Report on the Mollusca and Radiata of the Aegean Sea, and on their distribution, considered as bearing on geology, Report of the British Association for the Advancement of Science for 1843, 129-193, 1844.

Forest, J. and de Saint Laurent, M.: Présence dans la faune actuelle d'un représentant du groupe mésozoïque des Glyphéides: Neoglyphea inopinata gen. nov., sp. nov. (Crustacea decapoda Glypheidae), CR. Heb. Acad. Sci., Paris, 281, 1975.

Forest, J.: The Recent glypheids and their relationship with their fossil relatives (Decapoda, Reptantia), Crustaceana, 79, 795820, 2006.

Fosså, J. H., Lindberg, B., Christensen, O., Lundälv, T., Svellingen, I., Mortensen, P. B., and Alvsvåg, J.: Mapping of Lopehlia reefs in norway: experiences and survey methods, in: Cold-water Corals and Ecosystems, edited by: Freiwald, A. and Roberts, J. M., Berlin, Heidelberg, Springer, 359-391, 2005.

Fossing, H., Gallardo, V. A., Jorgensen, B. B., Huttel, M., Nielsen, L. P., Schulz, H., Canfield, D. E., Forster, S., Glud, R. N., Gundersen, J. K., Kuver, J., Ramsing, N. B., Teske, A., Thamdrup, B., and Ulloa, O.: Concentration and transport of nitrate by the mat-forming sulphur bacterium Thioploca, Nature, 374, 713$715,1995$.

Foubert, A., Beck, T., Wheeler, A. J., Opderbecke, J., Grehan, A., Klages, M., Thiede, J., and Henriet, J.-P. : New view of the Belgica Mounds, Porcupine Seabight, NE Atlantic: preliminary results from the Polarstern ARK-XIX/3a ROV cruise, in: ColdWater Corals and Ecosystems: Erlangen Earth Conference Series, edited by: Freiwald, A. and Roberts, J. M., Springer, Berlin, Heidelberg, 403-415, 2005.

Frederiksen, R., Jensen, A., and Westerberg, H.: The distribution of the scleractinian coral Lophelia pertusa around the Faroe Islands and the relation to internal mixing, Sarsia, 77, 157-171, 1992.

Freiwald, A., Fosså, J. H., Grehan, A., Koslow, T., and Roberts, J. M.: Cold-water Coral Reefs: Cambridge, UK, UNEP-WCMC, 84 p., 2004.

Freiwald, A.: Reef-forming cold-water corals, in: Ocean margin systems, edited by: Wefer, G., Billett, D. S. M., Hebbeln, D., Jørgensen, B. B., Schlüter, M., and Van Weering, T., Springer, Berlin, 365-385, 2002.

Freytag, J. K., Girguis, P. R., Bergquist, D. C., Andreas, J. P., Childress, J. J., and Fisher, C. R.: A paradox resolved: Sulfide acquisition by roots of seep tubeworms sustains net chemoautotrophy, P. Natl. Acad. Sci. USA, 98, 13408-13413, 2001.

Froelich, A. S.: Functional aspects of nutrient cycling on coral reefs. The ecology of deep shallow coral reefs, NOAA Symp Ser Undersea Res., edited by: Rosenstiel School of Marine and Atmospheric Science University of Miami, Rockville, MD, NOAA Undersea Research Program, 1, 133-139, 1983.

Fujiwara, Y., Kawato, M., Yamamoto, T., Yamanaka, T., SatoOkoshi, W., Noda, C., Tsuchida, S., Komai, T., Cubelio, S. S., Sasaki, T., Jacobsen, K., Kubokawa, K., Fujikura, K., Maruyama, T., Furushima, Y., Okoshi, K., Miyake, H., Miyazaki, M., Nogi, Y., Yatabe, A., and Okutani, T.: Three-year investigations into sperm whale-fall ecosystems in Japan, Mar. Ecol., 28, 219-232, 2007.
Gage, J. D.: High benthic species diversity in deep-sea sediments: The importance of hydrodynamics, in: Marine Biodiversity: Patterns and Processes, edited by: Ormond, R. P. G., Gage, J. D., and Angel, M. V., Cambridge University Press, Cambridge, 149177, 1997.

Gage, J.: Food inputs, utilisation, carbon flow and energetics, in: Ecosystems of the World. Ecosystems of the Deep Ocean, edited by: Tyler, P. A., Elsevier, Amsterdam, 313-426, 2003.

Gage, J. D. and Tyler, P. A.: Deep-Sea Biology: a Natural History of Organisms at the Deep-Sea Floor, Cambridge University Press, Cambridge, UK, 504 pp., 1991.

Gage, J. D., Lamont, P. A., and Tyler, P. A.: Deep-sea macrobenthic communities at contrasting sites off Portugal, preliminary results: II Spatial dispersion, Int. Rev. Ges. Hydrobio., 80, 251265, 1995.

Gage, J. D., Lamont, P. A., Kroeger, K., Paterson, G. L. J., and Gonzales Vecino, J. L.: Patterns in deep-sea macrobenthos at the continental margin: standing crop, diversity and faunal change on the continental slope off Scotland, Hydrobiologia, 440, 261271, 2000.

Galéron, J., Sibuet, M., Vanreusel, A., Mackenzie, K., Gooday, A. J., Dinet, A., and Wolff, G. A.: Temporal patterns among meiofauna and macrofauna taxa related to changes in sediment geochemistry at an abyssal NE Atlantic site, Prog. Oceanogr., 50, 303-324, 2001.

Gallardo, V. A.: Notas sobre la densidad de la fauna bentónica en el sublittoral del norte de Chile, Rev. Gayana, 10, 3-15, 1963.

Gallardo, V. A.: Large benthic microbial communities in sulfide biota under Peru-Chile subsurface countercurrent, Nature, 268, 331-332, 1977.

Gallardo, V. A. and Espinoza, C.: New communities of large filamentous sulfur bacteria in the eastern South Pacific, Int. Microbiol., 10, 97-102, 2007.

Gambi, C., Vanreusel, A., and Danovaro, R.: Biodiversity of nematode assemblages from deep-sea sediments of the Atacama Slope and Trench (South Pacific Ocean), Deep-Sea Res. Pt. I, 50, 103$117,2003$.

Genin, A.: Bio-physical coupling in the formation of zooplankton and fish aggregations over abrupt topographies, J. Mar. Syst., 50, 3-20, 2004.

German, C. R., Yoerger, D. R., Jakuba, M., Shank, T. M., Langmuir, C. H., and Nakamura, K.: Hydrothermal exploration with the Autonomous Benthic Explorer, Deep-Sea Res. Pt. I, 55, $203-$ 219, 2008.

Gili, J. M., Bouillon, J., Pagès, F., Palanques, A., and Puig, P.: Submarine canyons as habitats of prolific plankton populations: three new deep-sea Hydrodomedusae in the Western Mediterranean, Zool. J. Linn. Soc-Lond., 125, 313-329, 1999.

Glover, A. G., Smith, C. R., Paterson, G. L. J., Wilson, G. D. F., Hawkins, L., and Sheader, M.: Polychaete species diversity in the central Pacific abyss: local and regional patterns, and relationships with productivity, Mar. Ecol.-Prog. Ser., 240, 157-170, 2002.

Gooday, A., Todo, Y., Uematsu, K., and Kitazato, H.: New organicwalled Foraminifera (Protista) from the ocean's deepest point, the Challenger Deep (western Pacific Ocean), J. Linn. Soc., 153, 399-423, 2008. 
Gooday, A. J., Levin, L. A., Aranda da Silva, A., Bett, B. J., Cowie, G. L., Dissard, D., Gage, J. D., Hughes, D. J., Jeffreys, R., Lamont, P. A., Larkin, K. E., Murty, S. J., Schumacher, S., Whitcraft, C., and Woulds, C.: Faunal responses to oxygen gradients on the Pakistan margin: A comparison of foraminiferans, macrofauna and megafauna, Deep-Sea Res. Pt. II, 56, 488-502, 2009.

GOODS: Gloabal Opean Oceans and Deep Seabed (GOODS) biogeographic classification, edited by: Vierros, M., Cresswell, I., Escobar-Briones, E., Rice, J., and Ardron, J., UNEP, 95 pp., 2009.

Grasshoff, M.: Die Gorgonaria, Pennatularia und Antipatharia des Tiefwassers der Biskaya (Cnidaria, Anthozoa), Ergebnisse der französischen Expeditionen Biogas, Polygas, Géomanche, Incal, Nordatlante und Fahrten der Thalassa II. Taxonomischer Teil, Bull. Mus. Natn. Hist. Nat. Ser. 4, 3, A4, 941-978, 1982.

Grassle, J. F.: Slow recolonisation of deep-sea sediment, Nature, 26, 618-619, 1977.

Grassle, J. F. and Sanders, H. L.: Life histories and the role of disturbance, Deep-Sea Res., 20, 643-659, 1973.

Grassle, J. F., Brown-Leger, L. S., Morse-Porteous, L., Petrecca, R., and Williams, I.: Deep-sea fauna of sediments in the vicinity of hydrothermal vents, Bull. Biol. Soc. Washington, 6, 443-452, 1985.

Grassle, J. F.: Species diversity in deep-sea communities, Trends Ecol. Evol., 4, 12-15, 1989.

Grassle, J. F. and Maciolek, N. J.: Deep-sea species richness: regional and local diversity estimates from quantitative bottom samples, Am. Nat., 139, 313-341, 1992.

Gray, J. S.: Is deep-sea species diversity really so high? Species diversity of the Norwegian continental shelf, Mar. Ecol.-Prog. Ser., 112, 205-209, 1994.

Gray, J. S., Poore, G. C. B., Ugland, K. I., Wilson, R. S., Olsgard, F., and Johannesen, O.: Coastal and deep-sea benthic diversities compared, Mar. Ecol.-Prog. Ser., 159, 97-103, 1997.

Gray, J. S.: Marine diversity: the paradigms in patterns of species richness examined, Sci. Mar., 65, 41-56, 2001.

Gray, J. S.: Species richness of marine soft sediments, Mar. Ecol.Prog. Ser., 244, 285-297, 2002.

Grime, J. P.: Control of species density in herbaceous vegetation, J. Environ. Manage., 1, 151-167, 1973.

Guerra-García, J. M., Sorbe, J. C., and Frutos, I.: A new species of Liropus (Crustacea, Amphipoda, Caprellidae) from Le Danois bank (southern Bay of Biscay), Organisms Div. Evol., 7, 253, e1-253.e12, 2008.

Guinotte, J. M., Orr, J., Cairns, S., Friewald, A., Morgan, L., and George, R.: Will human-induced changes in seawater chemistry alter the distribution of deep-sea scleractinian corals?, Front. Ecol. Environ., 4, 141-146, 2006.

Hall-Spencer, J. M., Rogers, A., Davies, J., and Foggo, A.: Historical deep-sea coral distribution on seamount, oceanic island and continental shelf-slope habitats in the NE Atlantic, in: Conservation and adaptive management of seamount and deep-sea coral ecosystems, edited by: George, R. Y. and Cairns, S. D., Rosenstiel School of Marine and Atmospheric Science, University of Miami, Miami, 324 p., 2007.

Hall-Spencer, J. M., Allain, V., and Fossa, J. H.: Trawling damage to Northeast Atlantic ancient coral reefs, P. Roy. Soc. Lond. B, 269, 507-511, 2002.
Hashimoto, J., Miura, T., Fujikura, K., and Ossaka, J.: Discovery of vestimentiferan tube worms in the euphotic zone, Zool. Sci., 10, 1063-1067, 1993.

Heap, A. D., Anderson, T., Falkner, I., Przeslawski, R., Whiteway, T., and Harris, P. T.: Seascapes for the Australian margin and adjacent seabed, Geoscience Australia, Record, Canberra, 99 pp., 2009.

Helly, J. and Levin, L. A.: Global distribution of naturally occurring marine hypoxia on continental margins, Deep-Sea Res., 51, 1159-1168, 2004.

Hentschel, E.: Allgemeine Biologie des Südatlantischen Ozeans, Deutsche Atlantische Expedition auf dem Forschungsschiff "Meteor" 1925-1927, edited by: Defant, A., Berlin und Leipzig, Walter de Gruyter und Co., 11, 343, 1936.

Henry, L.-A. and Roberts, J. M.: Biodiversity and ecological composition of macrobenthos on cold-water coral mounds and adjacent off-mound habitat in the bathyal Porcupine Seabight, NE Atlantic, Deep Sea Res. Pt. I, 54, 654-672, 2007.

Henry, L.-A., Davies, A., and Roberts, M. J.: Beta diversity of coldwater coral reef communities off western Scotland, Coral Reefs, 29, 427-436, 2010.

Herring, P.: Species abundance, sexual encounter and bioluminescent signalling in the deep sea, Philos. T. Roy. Soc. Lond. B, 355, 1273-1276, 2000.

Herring, P.: The biology of the deep ocean, Oxford University Press, Oxford, 314 pp., 2002.

Hessler, R. R. and Sanders, M. L.: Faunal diversity in the deep-sea, Deep-Sea Res., 14, 65-78, 1967.

Heussner, S., Calafat, A., and Palanques, A.: Quantitative and qualitative features of particle fluxes in the North-Balearic Basin, in: EUROMARGE-NB Final Report, edited by: Canals, M., Casamor, J. L., Cacho, I., Calafat, A. M., and Monaco, A., MAST II Programme, EC, Vol. II, 41-66, 1996.

Holland, N. D., Clague, D. A., Gordon, D. P., Gebruk, A., Pawson, D. L., and Vecchione, M.: Lophenteropneust' hypothesis refuted by collection and photos of new deep-sea hemichordates, Nature, 434, 374-376, 2005.

Hollister, C. D. and MacCave, I. N.: Sedimentation under deep-sea storms, Nature, 309, 220-225, 1984.

Hoste, E., Vanhove, S., Schewe, I., Soltwedel, T., and Vanreusel, V.: Spatial and temporal variations in deep-sea meiofauna assemblages in the Marginal Ice Zone of the Arctic Ocean, Deep-Sea Res. Pt. I, 54, 109-129, 2007.

Houston, K. A. and Haedrich, R. L.: Abundance and biomass of macrobenthos in the vicinity of Carson Submarine Canyon, northwest Atlantic Ocean, Mar. Biol., 82, 301-305, 1984.

Hovland, M. and Mortensen, P. B.: Norske korallrev og prosesser i havbunnen, John Grieg forlag, Bergen, 155 pp., 1999.

Hovland, M.: Deep-water Coral Reefs Unique Biodiversity HotSpots, Praxis Publishing, UK XXVI, 278 p., 2008.

Huston, M.: A general hypothesis of species diversity: a critique and alternative parameters, Am. Nat., 113, 81-101, 1979.

IMMS (International Marine Minerals Society): Code for Environmental management of marine mining, Revised draft version from the International Marine Minerals Society adopoted code (2001), http://www.immsoc.org/IMMS_downloads/PAV _ Code_082109_KM_082509.pdf, last access: 22 January 2010, 2009. 
IPCC (Intergovernmental Panel on Climate Change): Climate Change 2007: Mitigation. Contribution of Working Group III to the Foruth Assessment Report of the Intergovernmental Panel on Climate Change, Cambridge University Press, Cambridge, 2007.

ISA (International Seabed Authority): Polymetallic sulphides and cobalt rich ferromanganese crust deposits: establishment of environmental baselines and an associated monitoring programme during exploration, Proceedings of the International Seabed Authority's workshop, Kingston, Jamaica, 6-10 September, 2004.

Jacobs, D. K. and Lindberg, D. R.: Oxygen and evolutionary patterns in the sea: Onshore/offshore trends and recent recruitment of deep-sea faunas, P. Natl. Acad. Sci. USA, 95, 9396-9401, 1998.

Jamieson, A. J., Fujii, T., Mayor, D. J., Solan, M., and Priede, I. G.: Hadal trenches: the ecology of the deepest places on Earth, Trends Ecol. Evol., 25, 190-197, 2010.

Jannasch, H. W.: Microbial interactions with hdyrothermal fluids, in: Seafloor hydrothermal systems: Physical, chemical, biological, and geolgical interactions, edited by: Humphris, S. E., Zierenberg, R. A., Mullineaux, L. S., and Thomson, R. E., Geol. Monog. Series, 91, American Geophysical Union, Washington, DC, 273-296, 1995.

Jannasch, H. W. and Wirsen, C. O.: Morphological survey of microbial mats near deep-sea thermal vents, Appl. Environ. Microbiol., 41, 528-538, 1981.

Jannasch, H. W. and Mottl, M. J.: Geomicrobiology of deep-sea hydrothermal vents, Science, 229, 717-725, 1985.

Jensen, P.: Nematode assemblages in the deep-sea benthos of the Norwegian Sea, Deep-Sea Res., 35, 1173-1184, 1988.

Jensen, A. and Frederiksen, R.: The fauna associated with the bankforming deepwater coral Lophelia pertusa (Scleractinaria) on the Faroe shelf, Sarsia, 77, 53-69, 1992.

Johnson, N. A., Campbell, J. W., Moore, T. S., Rex, M. A., Etter, R. J., McClain, C. R., and Dowell, M. D.: The relationship between the standing stock of deep-sea macrobenthos and surface production in the western North Atlantic, Deep-Sea Res. Pt. I, 54, 1350-1360, 2007.

Jonsson, L. G., Nilsson, P. G., Floruta, F., and Lundälv, T.: Distributional patterns of macro- and megafauna associated with a reef of the cold-water coral Lophelia pertusa on the Swedish west coast, Mar. Ecol.-Prog. Ser., 284, 163-171, 2004.

Jongsma, D., Fortuin, A. R., Huson, W., Troelstra, S. R., Klaver, G. T., Peters, J. M., van Harten, D., de Lange, G. J., and ten Haven, L.: Discovery of an anoxic basin within the Strabo Trench, eastern Mediterranean, Nature, 305, 795-797, 1983.

Jorgensen, B. B. and Boetius, A.: Feast and famine - microbial life in the deep-sea bed, Nat. Rev. Microbiol., 5, 770-781, 2007.

Jumars, P. A.: Methods for measurement of community structure in deep-sea macrobenthos, Mar. Biol., 30, 245-252, 1975.

Jumars, P. A.: Deep-sea species diversity: does it have a characteristic scale?, J. Mar. Res., 34, 217-246, 1976.

Kaiser, S. and Barnes, D. K. A.: Southern Ocean deep-sea biodiversity: sampling strategies and predicting responses to climate change, Climate Res., 37, 165-179, 2008.

Kano, A., Ferdelman, T. G., Williams, T., Henriet, J.-P., Ishikawa, T., Kawagoe, N., Talkashima, C., Kakizaki, Y., Abe, K., Sakai, S., Browning, E. L., and Li, X. H.: Age constraints on the origin and growth history of a deep-water coral mound in the northeast Atlantic drilled during Integrated Ocean Drilling Program
Expedition 307, Geology, 35, 1051-1054, 2007.

Karig, D. E.: Origin and development of marginal basins in the Western Pacific, J. Geophys. Res., 71, 2542-2561, 1971.

Keeling, R. F., Körtzinger, A., and Gruber, N.: Ocean Deoxygenation in a Warming World, Ann. Rev. Mar. Sci., 2, 199-229, 2010.

Keller, N. B.: The deep-sea madreporarian corals of the genus Fungiacyathus from the Kuril-Kamchatka and Aleutian Trenches and from some other areas of the World Oceans, Deep-sea bottom fauna of the Pacific Ocean, Glubokovodnaya donnaya fauna Tikhogo, Okeana, 99, Tr. Inst. Okeanol., 1976.

Kiel, S., and Little, C. T. S.: Cold-Seep Mollusks Are Older Than the General Marine Mollusk Fauna, Science, 313, 1429-1431, doi:10.1126/science.1126286, 2006.

Kiel, S. and Dando, P. R.: Chaetopterid tubes from vent and seep sites: Implications for fossil record and evolutionary history of vent and seep annelids, Acta Palaeontol. Pol., 54, 443-448, 2009.

King, N. J., Bagley, P. M., and Priede, I. G.: Depth zonation and latitudinal distribution of deep sea scavenging demersal fishes of the Mid-Atlantic Ridge, $42^{\circ}-53^{\circ} \mathrm{N}$, Mar. Ecol.-Prog. Ser., 319, 263-274, 2006.

Kitchingman, A. and Lai, S.: Inferences of potential seamount locations from mid-resolution bathymetric data., in: Seamounts: Biodiversity and Fisheries, edited by: Morato, T. and Pauly, D., Fisheries Centre, University of British Columbia, Vancouver, 7 12, 2004

Kvenvolden, K. A.: Methane hydrate and global climate, Global Biogeochem. Cy., 2, 221-229, 1988.

Koslow, J. A., Gowlett-Holmes, K., Lowry, J. K., O’Hara, T., Poore, G. C. B., and Williams, A.: Seamount benthic macrofauna off southern Tasmania: community structure and impacts of trawling, Mar. Ecol.-Prog. Ser., 213, 111-125, 2001.

Krogh, A.: Conditions of life at great depths in the ocean, Ecol. Monogr., 4, 430-439, 1934.

Kröncke, I., Vanreusel, A., Vincx, M., Wollenburg, J., Mackensen, V., Liebezeit, G., and Behrends, B.: The different benthic size compartments and their relation with sediment chemistry in the deep Eurasian Arctic Ocean, Mar. Ecol.-Prog. Ser., 199, 31-41, 2000.

Kurihara, $\mathrm{H}$.: Effects of $\mathrm{CO}_{2}$-driven ocean acidification on the early developmental stages of invertebrates, Mar. Ecol.-Prog. Ser., 373, 275-284, 2008.

Kussakin, O. G.: Peculiarities of the geographical and vertical distribution of marine isopods and the problem of deep-sea fauna origin, Mar. Biol., 23, 19-34, 1973.

Kunze, E., Dower, J. F., Beveridge, I., Dewey, R., and Bartlett, K. P.: Observations of Biologically generated turbulence in a coastal inlet, Science, 313, 1768-1770, 2006.

Lambshead, P. J. D.: Recent developments in marine benthic biodiversity research, Oceanus, 19, 5-24, 1993.

Lambshead, P. J. D., Tietjen, J., Ferrero, T. J., and Jensen, P.: Latitudinal diversity gradients in the deep sea with special reference to North Atlantic nematodes, Mar. Ecol.-Prog. Ser., 194, 159-167, 2000.

Lambshead, P. J. D., Tietjen, J., Moncrieff, C. B., and Ferrero, T. J.: North Atlantic latitudinal diversity patterns in deep-sea marine nematode data: a reply to Rex et al., Mar. Ecol.-Prog. Ser., 210, 299-301, 2001. 
Lambshead, P. J. D., Brown, C. J., Ferrero, T. J., Mitchell, N. J., Smith, C. R., Hawkins, L. E., and Tietjen, J.: Latitudinal diversity patterns for deep sea marine nematodes and organic fluxes: a test from the central equatorial Pacific, Mar. Ecol.-Prog. Ser., 236, 129-135, 2002.

Lambshead, P. J. D. and Boucher, G.: Marine nematode deep-sea biodiversity - hyperdiverse or hype?, J. Biogeogr., 30, 475-485, 2003.

Lambshead, P. J. D., Brown, C. J., Ferrero, T. J., Hawkins, L. E., Smith, C. R., and Mitchell, N. J.: Biodiveresity of nematode assemblages from the region of the mining Clarion-Clipperton Fracture Zone, an area of commercial mining interest, BMC Ecol., 3, 1-12, 2003.

Lampadariou, N. and Tselepides, A.: Spatial variability of meiofaunal communities at areas of contrasting depth and productivity in the Aegean Sea (NE Mediterranean), Prog. Oceanogr., 69, 1936, 2006.

Lampadariou, N., Tselepides, A., and Hatziyanni, E.: Deep-sea meiofaunal and foraminiferal communities along a gradient of primary productivity in the eastern Mediterranean Sea, Sci. Mar., 73, 337-345, 2009.

Lampitt, R. S.: Evidence for seasonal deposition of detritus to the deep-sea floor and its subsequent resuspension, Deep-Sea Res., 32, 885-897, 1985.

Lampitt, R. S. and Antia, A. N.: Particle flux in deep seas: regional characteristics and temporal variability, Deep-Sea Res. Pt. I, 44, 1377-1403, 1997.

Le Guilloux, E., Olu, K., Bourillet, J. F., Savoye, B., Iglésias, S. P., and Sibuet, M.: First observations of deep-sea coral reefs along the Angola margin: Deep Sea Res. Pt. II, 56, 2394-2403, 2009.

Lemche, H.: A new living deep-sea mollusc of the CambroDevonian class Monoplacophora, Nature, 179, 413-416, 1957.

Levin, L. A.: Oxygen minimum zone benthos: Adaptation and community response to hypoxia, Oceanogr. Mar. Biol., 41, 1-45, 2003.

Levin, L. A.: Ecology of cold seep sediments: Interactions of fauna with flow, chemistry and microbes, Oceanogr. Mar. Biol., 43, 146, 2005.

Levin, L. A. and Dayton, P. K.: Ecological theory and continental margins: where shallow meets deep, Trends Ecol. Evol., 24, 606-617, 2009.

Levin, L. A. and Gage, J. D.: Relationships between oxygen, organic matter and the diversity of bathyal macrofauna, Deep-Sea Res. Pt. II, 45, 129-163, 1998.

Levin, L. A., Plaia, G. R., and Huggett, C. L.: The influence of natural organic enchancement on life histories and community structure of bathyal polychaetes, in: Reproduction, larval biology, and recruitment of the deep-sea benthos, edited by: Young, C. M. and Eckelbarger, K. J., Columbia Universtity Press, New York, 336 pp., 1994.

Levin, L. A., Etter, R. J., Rex, M. A., Gooday, A. J., Smith, C. R., Pineda, J., Stuart, C. T., Hessler, R. R., and Pawson, D.: Environmental influences on regional deep-sea species diversity, Ann. Rev. Ecol. Syst., 32, 51-93, 2001.

Levin, L. A., Ziebis, W., Mendoza, G. F., Growney-Cannon, V., and Walther, S.: Recruitment response of methane-seep macrofauna to sulfide-rich sediments: An in situ experiment, J. Exp. Mar. Biol. Ecol., 330, 132-150, 2006.
Levin, L. A., Whitcraft, C., Mendoza, G. F., Gonzalez, J., and Cowie, G.: Oxygen and organic matter thresholds for benthic faunal activity on the Pakistan Margin oxygen minimum zone (700-1100 m), Deep-Sea Res. Pt. II., 56, 449-471, 2009.

Levin, L. A., Sibuet, M., Gooday, A. J., Smith, C. R., and Vanreusel, A.: The roles of habitat heterogeneity in generating and maintaining biodiversity on continental margins, Mar. Ecol., 31, 1-5, 2010a.

Levin, L. A., Mendoza, G. F., Gonzalez, J. P., Thurber, A. R., and Cordes, E. E.: Diversity of bathyal macrofauna on the northeastern Pacifici margin: the influence of methane sepes and oxygen mínimum zones, Mar. Ecol., 31, 94-111, 2010 b.

Linse, K., Griffiths, H. J., Barnes, D. K. A., and Clarke, A.: Biodiversity and biogeography of Antarctic and Sub-Antarctic Mollusca, Deep-Sea Res. Pt. II, 53, 985-1008, 2006.

Little, C. T. S., Campbell, K. A., and Herrington, R. J.: Why did ancient chemosynthetic seep and vent assemblages occur in shallower water than they do today?, Int. J. Earth Sci., 91, 149-153, 2002.

Little, C. T. S. and Vrijenhoek, R. C.: Are hydrothermal vent animals living fossils?, Trends Ecol. Evol., 18, 582-588, 2003.

Lonsdale, P.: Clustering of suspension-feeding macrobenthos near abyssal hydrothermal vents at oceanic spreading centers, DeepSea Res., 24, 857-863, 1977.

Lorion, J., Duperron, S. B., Gros, O., Cruaud, C., and Samadi, S.: Several deep-sea mussels and their associated symbionts are able to live both on wood and on whale falls, P. Roy. Soc. B., 276, 177-185, doi:10.1098/rspb.2008.1101, 2009.

Lutz, R. A., Fritz, L. W., and Cerrato, R. M.: A comparison of bivalve (Calyptogena magnifica) growth at two deep-sea hydrothermal vents in the eastern Pacific, Deep-Sea Res., 35, 1793$1810,1988$.

Lutz, R. A., Shank, T. M., Fornari, D. J., Hyamon, R. M., Lilley, M. D., Von Damm, K. L., and Desbruyères, D.: Rapid growth at deep-sea vents, Nature, 371, 663-664, 1994.

MacDonald, I. R., Bohrmann, G., Escobar, E., Abegg, F., Blanchon, P., Blinova, V., Bruckmann, W., Drews, M., Eisenhauer, A., Han, X., Heeschen, K., Meier, F., Mortera, C., Naehr, T., Orcutt, B., Bernard, B., Brooks, J., and de Farago, M.: Asphalt Volcanism and Chemosynthetic Life in the Campeche Knolls, Gulf of Mexico, Science, 304, 999-1002, 2004.

Maciolek, N., Grassle, J. F., Hecker, B., Brown, B., Blake, J. A., Boehm, P. D., Petrecca, R., Duffy, S., Baptiste, E., and Ruff, R. E.: Study of biological processes on the U.S. North Atlantic slope and rise, Final Report prepared for U.S. Department of the Interior, Minerals Management Service, under Contract No. 1412-0001-30064, 310 pp. + Appendices A-M., 1987.

Macpherson, E., Jones, W., and Segonzac, M.: A new squat lobster family of Galatheoidea (Crustacea, Decapoda, Anomura) from the hydrothermal vents of the Pacific-Antarctic Ridge, Zoosystema, 27, 709-723, 2005.

Madsen, F. J.: Octocorallia (Stolonifera - Telestacea - Xeniidea - Alcyonacea - Gorgonacea), The Danish Ingolf-Expedition, V, 13, 65 pp., with 1 plate and 53 figures in the text, 1944.

Maier, C., Hegeman, J., Weinbauer, M. G., and Gattuso, J.-P.: Calcification of the cold-water coral Lophelia pertusa, under ambient and reduced $\mathrm{pH}$, Biogeosciences, 6, 1671-1680, doi:10.5194/bg6-1671-2009, 2009. 
Malahoff, A.: Geology of the summit of Loihi submarine volcano, in: Volcanism in Hawaii, edited by: Decker, R. W., Wright, T. L., and Stauffer, P. H., US Geological Survey Professional Paper, 1350, 133-144, 1987.

Mastrototaro, F., D’Onghia, G., Corriero, G., Matarrese, A., Maiorano, P., Panetta, P., Gherardi, M., Longo, C., Rosso, A., Sciuto, F., Sanfilippo, R., Gravili, C., Boero, F., Taviani, M., and Tursi, A.: Biodiversity of the white coral bank off Cape Santa Maria di Leuca (Mediterranean Sea): An update, Deep Sea Res. Pt. II, 57 , 412-430, 2010.

Margulis, L., Corliss, J. O., Melkonian, M., and Chapman, D. J.: Handbook of the Protoctista, Jones and Bartlett, Boston, 1989.

Marshall, N. B.: DeepSea Biology: Developments and Perspectives, Garland, STMP Press, 566 pp., 1979.

Maurer, D., Diener, D. E., Robertson, G., and Gerlinger, T.: Comparison of community structure of soft-bottom macrobenthos of the Newport Submarine Canyon, California and adjoining self, Int. Rev. Ges. Hydrobio., 79, 519-603, 1994.

May, R. M.: How many species are there on Earth?, Science, 241, 1442-1449, 1988.

May, R. M.: Biological diversity: differences between land and sea, Philos. T. Rot. Soc. Lond. B., 343, 105-111, 1994.

Menzies, R. J., George, R. Y., and Rowe, G. T.: Abyssal Environment and Ecology of the World Oceans, John Wiley and Sons, New York, 323-327, 1973.

McClain, C. R., Rex, M. A., and Jabbour, R.: Deconstructing bathymetric body size patterns in deep-sea gastropods, Mar. Ecol.Prog. Ser., 297, 181-187, doi:10.3354/meps297181, 2005.

McClain, C. R., Boyer, A. G., and Rosenberg, G.: The island rule and the evolution of body size in the deep sea, J. Biogeogr., 33, 1578-1584, 2006.

Menot, L., Sibuet, M., Carney, R. S., Levin, L. A., Rowe, G. T., Billett, D. S. M., Poore, G., Kitazato, H., Vanreusel, A., Galéron, J., Lavrado, H. P., Sellanes, J., Ingole, B., and Krylova, E. M.: New perceptions of continental margin biodiversity, in: Life in the World's Oceans: Diversity, Distribution, and Abundance, edited by: McIntyre, A. D., Chapter 5, Wiley-Blackwell, 79-103, 2010.

Messing, C. G., Reed, J. K., Brooke, S. D., and Ross, S. W.: DeepWater Coral Reefs of the United States, in: Coral Reefs of the USA, Volume 1: Coral Reefs of the World, edited by: Riegl, B. M. and Dodge, R. E., Springer, The Netherlands, 767-791, 2008

Messing, C. G., Neumann, C. A., and Lang, J. C.: Biozonation of Deep-Water Lithoherms and Associated Hardgrounds in the Northeastern Straits of Florida, Palaios, 5, 15-33, 1990.

Mienis, F., de Stigter, H. C., White, M., Dulneveldc, G., de Haas, H., and van Weering, T. C. E.: Hydrodynamic controls on coldwater coral growth and carbonate-mound development at the SW and SE rockall trough margin, NE Atlantic ocean, Deep-Sea Res. Pt. I, 54, 1655-1674, 2007.

Miljutina, M. A., Miljutin, D. M., Mahatma, R., and Galéron, J.: Deep-sea nematode assemblages of the Clarion-Clipperton Nodule Province (Tropical North-Eastern Pacific), Mar. Biodivers., 40, 1-15, 2010.

Milkov, A. V.: Worldwide distribution of submarine mud volcanoes and associated gas hydrates, Mar. Geol., 167, 29-42, 2000.

Mokievsky, V. and Azovsky, A.: Re-evaluation of species diversity patterns of free-living marine nematodes, Mar. Ecol.-Prog. Ser., 238, 101-108, 2002.
Monniot, F.: Faunal affinities among abyssal Atlantic basins, Sarsia, 64, 93-95, 1979.

Mora, C., Tittensor, D. P., and Myers, R. A.: The completeness of taxonomic inventories for describing the global diversity and distribution of marine fishes, P. Roy. Soc. B., 275, 149-155, 2008.

Mortensen, P. B. and Buhl-Mortensen, L.: Distribution of deepwater gorgonian corals in relation to benthic habitat features in the Northeast Channel (Atlantic Canada), Mar. Biol., 144, 12231238, 2004.

Mortensen, P. B. and Fosså, J. H.: Species diversity and spatial distribution of invertebrates on Lophelia reefs in Norway, Proceedings of the 10th International Coral Reef Symposium, Okinawa, Japan, 1849-1868, 2006.

Mortensen, P. B., Hovland, M., Brattegard, T., and Farestveit, R.: Deep water bioherms of the scleractinian coral Lophelia pertusa (L.) at $64^{\circ} \mathrm{N}$ on the Norwegian shelf: structure and associated megafauna, Sarsia, 80, 145-158, 1995.

Mortensen, P. B., Buhl-Mortensen, L., and Gordon Jr., D. C.: Distribution of deep-water corals in Atlantic Canada, Proceedings of the 10th International Coral Reef Symposium, Okinawa, Japan, 1832-1848, 2006.

Mortensen, P. B., Buhl-Mortensen, L., Gebruk, A. V., and Krylova, E. M.: Occurrence of deep-water corals on the Mid-Atlantic Ridge based on MAR-ECO data, Deep-Sea Res. Pt. II, 55, 142152, 2008.

Moseley, H. N.: Deep-sea dredging and life in the deep sea, Nature, 21, 591-593, 1880.

Murray, J. and Hjort, J.: The depths of the ocean, Macmillan London, 821 pp., 1912.

Muthumbi, A. W., Vanreusel, A., Duineveld, G., Soetaert, K., and Vincx, M.: Nematode community structure along the continental slope off the Kenyan coast, Western Indian Ocean, Int. Rev. Hydrobiol., 89, 188-205, 2004.

Myers, A. A. and Hall-Spencer, J. M.: A new species of amphipod crustacean, Pleusymtes comitari sp. nov., associated with Acanthogorgia sp. gorgonians on deep-water coral reefs off Ireland, J. Mar. Biol. Assoc. UK, 84, 1029-1032, 2004.

Narayanaswamy, B. E., Bett, B. J., and Gage, J. D.: Ecology of bathyal polychaete fauna at an Arctic-Atlantic boundary (FaroeShetland Channel, North-east Atlantic), Mar. Biol. Res., 1, 2032, 2005.

Narayanaswamy, B. E., Howell, K. L., Hughes, D. J., Davies, J. S., Roberts, J. M., and Black, K. D.: Strategic Environmental Assessment Area 7 Photographic Analysis, 103 pp.; appendix 199 pp. - Report for the Department of Trade and Industry, 2006.

Narayanaswamy, B. E., Bett, B. J., and Hughes, D. J.: Deep-water macrofaunal diversity in the Faroe-Shetland region 1 (NE Atlantic): a margin subject to an unusual thermal regime, Mar. Ecol., 31, 237-247, 2010.

Netto, S. A., Galluci, F., and Fonseca, G. F. C.: Meiofauna communities of continental slope and deep-sea sites off SE Brazil, Deep-Sea Res. Pt. I, 52, 845-859, 2005.

Neumann, A. C., Kofoed, J. W., and Keller, G. H.: Lithoherms in the strait of Florida, Geology, 5, 4-10, 1977.

O'Hara, T. D. and Tittensor, D. P.: Environmental drivers of ophiuroid species richness on seamounts, Mar. Ecol., 31, 1-13, 2010.

Oliveira, A., Santos, A. I., Rodrigues, A., and Vitorino, J.: Sedimentary particle distribution and dynamics on the Nazare canyon system and adjacent shelf (Portugal), Mar. Geol., 246, 105-122, 
2007.

OU (Open University): The Ocean basins: their structure and evolution, The Open University Oceanography, ButterworthHeinemann, Oxford, 192 pp., 1998.

Paterson, G. L. J. and Lambshead, P. J. D.: Bathymetric patterns of polychaete diversity in the Rockall Trough, Northeast Atlantic. Deep-Sea Res., 42, 1199-1214, 1995.

Parin, N. V., Mironov, A. N., and Nesis, K. N.: Biology of the Nazca and Sala y Gomez submarine ridges, an outpost of the Indo-West Pacific fauna in the Eastern Pacific Ocean: Composition and distribution of the fauna, its communities and history, Adv. Mar. Biol., 32, 145-242, 1997.

Paterson, G. L. J. and Lambshead, P. J. D.: Bathymetric patterns of polychaete diversity in the Rockall Trough, northeast Atlantic, Deep-Sea Res. Pt. II, 42, 1199-1214, 1995.

Paull, C. K., Hecker, B., Commeau, R., Freeman-Lynde, R. P., Neuman, C., Corso, W. P., Golubic, S., Hook, J. E., Sikes, J. E., and Curray, J.: Biological communities at the Florida Escarpment resemble hydrothermal vent taxa, Science, 226, 965-967, 1984.

Paull, C. K., Neumann, A. C., Ende, B. A., Ussler III, W., and Rodriguez, N. M.: Lithoherms on the Florida-Hatteras slope, Mar. Geol., 166, 83-101, 2000.

Pauly, D., Alder, J., Bennett, E., Christensen, V., Tyedmers, P., and Watson, R.: The future for fisheries, Science, 302, 1359-1361, 2003.

Pauly, D., Watson, R., and Alder, J.: Global trends in world fisheries: impacts on marine ecosystems and food security, Philos. T. Roy. Soc. B., 360, 5-12, 2005.

Peters, R. H.: The ecological implications of body size, Cambridge University Press, Cambridge, 329 pp., 1983.

Pfannkuche, O. and Thiel, H.: Meiobenthic Stocks and Benthic Activity on the NE-Svalbard Shelf and in the Nansen Basin, Polar Biol., 7, 253-266, 1987.

Pineda, J. and Caswell, H.: Bathymetric species-diversity patterns and boundary constraints on vertical range distributions, DeepSea Res. Pt. II, 45, 83-101, 1998.

Polovina, J. J., Howell, E. A., and Abecassis, M.: Ocean's least productive waters are expanding, Geophys. Res. Lett., 35, L03618, doi:10.1029/2007GL031745, 2008.

Poore, G. C. B. and Wilson, G. D. F.: Marine species richness, Nature, 361, 597-598, 1993.

Post, A. L., Hemer, M. A., O’Brien, P. E., Roberts, D., and Craven, M.: History of benthic colonization beneath the Amery ice shelf, East Antarctica, Mar. Ecol.-Prog. Ser., 344, 29-37, 2007.

Puig, P., Ogsto, A. S., Mullenbach, B. L., Nittrouer, C. A., and Sternberg, R. W.: Shelf-to-canyon sediment transport processes on the Eel Continental Margin (Northern California), Mar. Geol., 193, 129-149, 2003.

Raes, M., Armin, R., and Vanreusel, A.: Response of nematode communities after large-scale ice-shelf collapse events in the Antarctic Larsen area, Global Change Biol., 16, 1618-1631, 2010.

Ramirez-Llodra, E.: Fecundity and Life-history Strategies in Marine Invertebrates, Adv. Mar. Biol., 43, 88-170, 2002.

Ramirez-Llodra, E., Ballesteros, M., Company, J. B., Dantart, L., and Sardà, F.: Spatio-temporal variations in the diversity, biomass and abundance of bathyal invertebrates in the Catalan Sea (Western Mediterranean), Mar. Biol., 153, 297-309, 2008.
Ramirez-Llodra, E., Company, J. B., Sardà, F., and Rotllant, G.: Megabenthic diversity patterns and community structure of the Blanes submarine canyon and adjacent slope in the Northwestern Mediterranean: a human overprint?, Mar. Ecol., 31, 167-183, 2010.

Ramirez-Llodra, E., Tyler, P. A., Rowden, A. A., Levin, L., Smith, C., Clark, M. R., Escobar, E., Aksel Bergstad, O., Baker M. C., Rogers, A., Van Dover, C. L., and Menot, L.: Man and the last great wilderness: human impact on the deep sea, PLOS ONE, in preparation, 2010.

Rea, A. D. K., Lyle, M. W., Liberty, L. M., Hovan, S. A., Bolyn, M. P., Gleason, J. D., Hendy, I. L., Ltimer, J. C., Murphy, B. M., Owen, R. M., Paul, C. F., Rea, T. H., Stancin, A. M., and Thomas, A. D. J.: Broad region of no sediment in the southwest Pacific Basin, Geology, 34, 873-876, 2006.

Reaka-Kudla, M. L.: The global diversity of coral reefs: a comparison with rain forests, in: Biodiversity II: understanding and protecting our natural resources, Joseph Henry Press, 1997.

Reed, J. K.: Submersible studies of deep-water Oculina and Lophelia coral banks off southeastern U.S.A., in: Diving for Science, edited by: Cahoon, L. B., Wilmington, University of North Carolina, 143-151, 1992.

Reichart, G. L., Lourens, L. J., and Zachariasse, W. J.: Temporal variability in the northern Arabian Sea oxygen minimum zone (OMZ) during the last 225,000 years, Paleoceanography, 13, 607-621, 1998.

Relexans, J. C., Deming, J., Dinet, A., Gaillard, J. F., and Sibuet, M.: Sedimentary organic matter and micro-meiobenthos with relation to trophic conditions in the tropical northeast Atlantic, Deep-Sea Res. Pt. I, 43, 1343-1368, 1996.

Renaud, P. E., Ambrose, W. G., Vanreusel, A., and Clough, L. M.: Nematode and macrofaunal diversity in central Arctic Ocean benthos, J. Exp. Mar. Biol. Ecol., 330, 297-306, 2006.

Reveillaud, J., Freiwald, A., Van Rooij, D., Le Guilloux, E., Altuna, A., Foubert, A., Vanreusel, A., Olu-Le Roy, K., and Henriet, J. P.: The distribution of scleractinian corals in the Bay of Biscay, NE Atlantic, Facies, 54, 317-331, 2008.

Rex, M. A.: Community structure in the deep-sea benthos, Ann. Rev. Ecol. Evol., 12, 331-353, 1981.

Rex, M. A.: Geographic patterns of species diversity in the deepdea benthos, in: The Sea, edited by: Rowe, G. T., J. Wiley \& sons, New York, 453-472, 1983.

Rex, M. A., Stuart, C. T., Hessler, R. R., Allen, J. A., Sanders, H. L., and Wilson, G. D. F.: Global-scale latitudinal patterns of species diversity in the deep-sea benthos, Nature, 365, 636-639, 1993.

Rex, M. A., Etter, R. J., and Stuart, C. T.: Large-scale patterns of species diversity in the deep-sea benthos, in: Marine Biodiversity: Patterns and Processes, edited by: Ormond, R. P. G., Gage, J. D., and Angel, M. V., Cambridge University Press, Cambridge, 95-121, 1997.

Rex, M. A. and Etter, R. J.: Bathymetric patterns of body size: implications for deep-sea biodiversity, Deep-Sea Res. Pt. II, 45, 103-127, 1998.

Rex, M. A., Stuart, C. T., and Coyne, G.: Latitudinal gradients of species richness in the deep-sea benthos of the North Atlantic, Proceedings of the National Academy of Sciences of the United States of America, 97, 4082-4085, 2000. 
Rex, M. A., Stuart, C. T., and Etter, R. J.: A comment on whether deep-sea nematodes show a positive latitudinal gradient of species diversity, The potential role of depth, Mar. Ecol.-Prog. Ser., 210, 297-298, 2001.

Rex, M. A., Crame, J. A., Stuart, C. T., and Clarke, A.: Largescale biogeographic patterns in marine mollusks: A confluence of history and productivity?, Ecology, 86, 2288-2297, 2005a.

Rex, M. A., McClain, C. R., Johnson, N. A., Etter, R. J., Allen, J. A., Bouchet, P., and Warén, A.: A source-sink hypothesis for abyssal biodiversity, Am. Nat., 165, 163-178, 2005b.

Rex, M. A., Etter, R. J., Morris, J. S., Crouse, J., McClain, C. R., Johnson, N. A., Stuart, C. T., Deming, J. W., Thies, R., and Avery, R.: Global bathymetric patterns of standing stock and body size in the deep-sea benthos, Mar. Ecol.-Prog. Ser., 317, 1-8, 2006.

Rice, A. L., Aldred, R. G., Billett, D. M. S., and Thurston, M. H.: The combined use of an epibenthic sledge and deep-sea camera to give quantitative relevance to macro-benthic samples, Ambio Special Report, 6, 59-72, 1979.

Richter, T. O., de Stigter, H. C., Boer, W., Jesús, C. C., and van Weering, T. C. E.: Dispersal of natural and anthropogenic lead through submarine canyons at the Portuguese margin, Deep-Sea Res. Pt. I, 56, 267-282, 2009.

Riddle, M. J., Craven, M., Goldsworthy, P. M., and Carsey, F.: A diverse benthic assemblage $100 \mathrm{~km}$ from open water under the Amery Ice Shelf, Antarctica, Paleoceanography, 22, PA1204, doi:10.1029/2006PA001327, 2007.

Roberts, J. M., Wheeler, A. J., Freiwald, A., and Cairns, A. F.: The biology and geology of deep-sea coral habitats, Cambridge University Press, Camridge, UK, 334 pp., 2009.

Roberts, J. M., Wheeler, A. J., and Freiwald, A.: Reefs of the deep: the biology and geology of cold-water coral ecosystems, Science, 312, 543-547, 2006.

Roberts, J. M., Henry, L.-A., Long, D., and Hartley, J. P.: Coldwater coral reef frameworks, megafaunal communities and evidence for coral carbonate mounds on the Hatton Bank, north east Atlantic, Facies, 54, 297-316, 2008.

Robison, B. H.: Deep pelagic biology, J. Exp. Mar. Biol. Ecol., 300, 253-272, 2004.

Robison, B. H.: Conservation of deep pelagic biodiversity, Conserv. Biol., 23, 847-858, 2009.

Robinson, C., Steinberg, D. K., Anderson, T. R., Aristegui, J., Carlson, C. A., Frost, J. R., Ghiglione, J.-F., Hernandez-Leon, S., Jackson, G. A., Koppelmann, R., Queguiner, B., Ragueneau, O., Rassoulzadegan, F., Robison, B. H., Tambourini, C., Tanaka, T., Wishner, K. F., and Zhang, J.: Mesopelagic zone ecology and biogeochemistry - a synthesis, Deep-Sea Res. Pt. II, 57, 15041518, 2010.

Robison, B. H., Sherlock, R. E., and Reisenbichler, K. R.: The bathypelagic community of Monterrey Canyon, Deep-Sea Res. Pt. II, 57, 1551-1556, 2010.

Roether, W. B., Manc, B., Klein, B., Bregant, D., Georgopoulos, D., Beitzel, V., Kocacevic, V., and Luchetta, A.: Recent changes in eastern Mediterranean deep waters, Science, 271, 333-335, 1996.

Rogers, A. D.: The biology of seamounts, Adv. Mar. Biol., 30, 305$350,1994$.
Rogers, A. D.: The biology of Lophelia pertusa (Linnaeus 1758) and other deep-water reef-forming corals and impacts from human activities, Int. Rev. Hydrobiol., 84, 315-406, 1999.

Rogers, A. D.: The role of oceanic oxygen minima in generating biodiversity in the deep sea, Deep-Sea Res. Pt. II, 47, 119-148, 2000.

Rona, P. A., Klinkhammer, G., Nelsen, T. A., Tefry, J. H., and Elderfield, H.: Black smokers, massive suphides and vent biota at the Mid-Atlantic Ridge, Nature, 321, 33-37, 1986.

Rona, P. A.: Resources of the seafloor, Science, 299, 673-674, 2003.

Rose, A., Seifried, S., Willen, E., George, K. H., Veit-Köhler, G., Bröhldick, K., Drewes, J., Moura, G., Martínez Arbizu, P., and Schminke, H. K.: A method for comparing within-core alpha diversity values from repeated multicorer samplings, shown for abyssal Harpacticoida (Crustacea: Copepoda) from the Angola Basin, Org. Divers. Evol., 5, 3-17, 2005.

Rosenzweig, M. L.: Species diversity in space and time, Cambridge University Press, Cambridge, 1995.

Rotllant, G., Abad Holgado, E., Sardà, F., Ábalos, M., Company, J. B., and Rivera, J.: Dioxin compounds in the deep-sea rose shrimp Aristeus antennatus (Risso, 1816) throughout the Mediterranean Sea, Deep-Sea Res. Pt. I, 53, 1895-1906, 2006.

Roux, M., Rio, M., Schein, E., Lutz, E., Frltz, L. W., and Ragone, L. M.: Mesures in situ de la croissance des bivalves et des vestimentiferes et de la corrosion des coquilles au site hydrothermal de $13^{\circ} \mathrm{N}$ (dorsale du Pacifique oriental), C. R. Acad. Sci., 308, 121-127, 1989.

Rowe, G. T., Polloni, P. T., and Haedrich, R. L.: The deep-sea macrobenthos on the continental margin of the northwest Atlantic Ocean, Deep-Sea Res., 29, 257-278, 1982.

Rowe, G. T.: Biomass and production of the deep-sea macrobenthos, in: Deep-sea Biology, edited by: Rowe, G. T., Wiley, New York, 97-121, 1983.

Rowe, G. T., Wei, C., Nunnally, C., Haedrich, R., Montagna, P., Baguley, J. G., Bernhard, J. M., Wicksten, M., Ammons, A., Briones, E. E., Soliman, Y., and Deming, J. W.: Comparative biomass structure and estimated carbon flow in food webs in the deep Gulf of Mexico, Deep-Sea Res. Pt. II, 55, 2699-2711, 2008.

Sakshaug, E. and Skjoldal, H. R.: Life at the ice edge, Ambio, 18, 60-67, 1989.

Sakshaug, E.: Biomass and productivity distributions and their variability in the Barents Sea, International Council for the Exploration of the Sea, J. Mar. Sci., 54, 341-350, 1997.

Samedi, S., Quéméré, E., Lorion, J., Tillier, A., von Cosel, R., Lopez, P., Cruaud, C., Couloux, A., and Boisselier-Dubayle, M.C.: Molecular phylogeny in mytilids supports the wooden steps to deep-sea vents hypothesis, C. R. Biol., 330, 446-456, 2007.

Sanders, H. L.: Marine benthic diversity: a comparative study, Am. Nat., 102, 243-282, 1968.

Sanders, H. L.: Benthic marine diversity and the stabilitytime hypothesis, Diversity and Stability in Ecological Systems, Brookhaven Symposia in Biology, 71-80, 1969.

Sanders, H. L.: Evolutionary ecology and life-history patterns in the deep sea, Sarsia, 64, 1-7, 1979.

Sardà, F., Cartes, J., and Company, J. B.: Spatio-temporal variations in megabenthos abundance in three different habitats on the Catalan deep-sea (Western Mediterranean), Mar. Biol., 120, 211-219, 1994a. 
Sardà, F., Cartes, J., and Norbis, W.: Spatio-temporal structure of the deep-water shrimp Aristeus antennatus (Decapoda: Aristeidae) population in the western Mediterranean, Fish. B-NOAA, 92, 599-607, 1994b.

Sardà, F., Maynou, F., and Tallo, L.: Seasonal and spatial mobility patterns of rose shrimp Aristeus antennatus in the Western Mediterranean: results of a long-term study, Mar. Ecol.-Prog. Ser., 159, 133-141, 1997.

Sardà, F., Company, J. B., Bahamon, N., Rotllant, G., Flexas, M. A., Sánchez, J., Zúñiga, D., Coenjaerts, J., Orellana, D., Jordá, G., Puigdefàbregas, J., Sanchez-Vidal, A., Calafat, A., Martin, D., and Espino, M.: Relationship between environment and occurence of the deep-water rose shrimp Aristeus antennatus (Risso, 1816) in the Blanes submarine canyon (NW Mediterranean), Prog. Oceanogr., 82, 227-238, 2009.

Sars, M., Beretningom, E. N., and Sommeren, I.: Foretagen Zoologisk Reise I Lofoten og Finmarken, Cristiana, 1849.

Schewe, I. and Soltwedel, T.: Deep-sea meiobenthos of the central Arctic Ocean: Distribution patterns and size-structure under extreme oligotrophic conditions, Vie et milieu, 49, 79-92, 1999.

Schewe, I.: Small-sized organisms of the Alpha Ridge, Central Arctic Ocean, Int. Rev. Hydrobiol., 86, 317-335, 2001.

Schlacher, T. A., Williams, A., Althaus, F., and SchlacherHoenlinger, M. A.: High-resolution seabed imagery as a tool for biodiversity conservation planning on contienental margins, Mar. Ecol., 31, 200-222, 2010.

Schlacher, T. A., Rowden, A. A., Dower, J. F., and Consalvey, M.: Seamount science scales undersea mountains: new research and outlook, Mar. Ecol., 31 (Supl. 1), 1-13, 2010.

Schwabe, E.: A summary of reports of abyssal and hadal Monoplacophora and Polyplacophora (Mollusca), Zootaxa, 1866, 205222, 2008.

Scoffin, T. P. and Bowes, G. E.:The Facies Distribution of Carbonate Sediments on Porcupine Bank, Northeast Atlantic, Sediment. Geol., 60, 125-134, 1988.

Scoffin, T. P., Alexandersson, T. E., Bowes, G. E. J., Farrow, G. E., and Milliman, J. D.: Recent, temperate, sub-photic, carbonate sedimentation: Rockall Bank, northeast Atlantic, J. Sediment. Petrol., 50, 331-356, 1980.

Sebens, K. P.: The limits to indeterminate growth: an optimal size model applied to passive suspension feeders, Ecology, 63, 209222, 1982.

Sebens, K. P.: The ecology of indeterminate growth in animals, Ann. Rev. Ecol., 18, 371-407, 1987.

Seifried, S.: The Importance of a Phylogenetic System for the Study of Deep-Sea Harpacticoid Diversity, Zool. Stud., 43, 435-445, 2004.

Sepkoski Jr., J. J.: A Model of Onshore-Offshore Change in Faunal Diversity, Paleobiology, 17, 58-77, 1991.

Shank, T. M.: The Evolutionary Puzzle of Seafloor Life, Oceanus, 42, 19-22, 2004.

Sibuet, M.; Distribution and diversity of asteroids in Atlantic abyssal basins, Sarsia, 64, 85-91, 1979.

Sibuet, M. and Olu, K.: Biogeography, biodiversity and fluid dependence of deep sea cold seeps communities at active and passive margins, Deep-Sea Res. Pt. II, 45, 517-567, 1998.

Sibuet, M., Calmet, D. O., and Auffret, G. A.: Reconnaissance photographique de conteneurs en place dans la zone d'immersion des déchets faiblement radioactifs de l'Atlantique Nord-Est, C.
R. Acad. Sci. Paris Ser. C, 301, 497-502, 1985.

Siezen, R. J., and Wilson, G.: Genomics of deep-sea and subseafloor microbes, Microbial Biotech., 2, 157-163, 2009.

Smith, W. O. and Sakshaug, E.: Polar phytoplankton, in: Polar Oceanography, Part B, edited by: Smith, W. O., Academic Press, London, 477-525, 1990.

Smith, C. R.: Bigger is better: The role of whales as detritus in marine ecosystems, in: Whales, Whaling and Ocean Ecosystems, edited by: Estes, P. D., De Master, D. P., Brownell Jr., R. L., Doak, D. F., William, T. M., and Berkeley, D., University of California Press, 286-301, 2006.

Smith, C. R., Kukert, H., Wheatcroft, R. A., Jumars, P. A., and Deming, J. W.: Vent fauna on whale remains, Nature, 341, 2728, 1989.

Smith, C. R., Hoorer, D. J., Doan, S. E., Pope, R. H., DeMaster, D. J., Dobbs, F. C., and Altabet, M. A.: Phytodetritus of the abyssal seafloor across $10^{\circ}$ of latitude in the central equatorial Pacific, Deep-Sea Res. Pt. II, 43, 1309-1338, 1996.

Smith, C. R. and Baco, A. R.: Ecology of whale falls at the deep-sea floor, Oceanogr. Mar. Biol., 41, 311-354, 2003.

Smith, A. B. and Stockley, B.: The geological history of deepsea colonization by echinoids: roles of surface productivity and deep-water ventilation, P. Roy. Soc. B., 272, 865-869, doi:10.1098/rspb.2004.2996, 2005.

Smith, C. R., De Leo, F. C., Bernardino, A. F., Sweetman, A. K., and Martinez Arbizu, P.: Abyssal food limitation, ecosystem structure and climate change, Trends Ecol. Evol., 23, 518-528, 2008.

Snelgrove, P. V. R. and Smith, C. R.: A riot of species in an environmental calm; The paradox of the species-rich deep sea, Oceanogr, Mar. Biol. Ann. Rev., 40, 311-342, 2002.

Snelgrove, P. V. R.: Discoveries of the Census of Marine Life: Making Ocean Life Count, Cambridge University Press, Cambridge, 304 pp., 2010.

Soetaert, K. and Heip, C.: Nematode assemblages of deep-sea and shelf break sites in the North Atlantic and the Mediterranean Sea, Mar. Ecol.-Prog. Ser., 125, 171-183, 1995.

Soetaert, K., Vincx, M., and Heip, C.: Nematode community structure along a Mediterranean shelf-slope gradient, Mar. Ecol., 16, 189-206, 1995.

Solow, A. R. and Smith, W. K.: On estimating the number of species from the discovery record, P. Roy. Soc. B., 272, 285-287, 2005.

Soltwedel, T.: Metazoan meiobenthos along continental margins: a review, Prog. Oceanogr., 46, 59-84, 2000.

Soltwedel, T., Mokievsky, V., and Schewe, I.: Benthic activity and biomass on the Yermak Plateau and in adjacent deep-sea regions northwest of Svålbard, Deep-Sea Res. Pt. I, 47, 1761$1785,2000$.

Spalding, M. D., Fox, H. E., Allen, G. R., Davidson, N., Ferdana, Z. A., Finlayson, M., Halpern, B. S., Jorge, M. A., Lombana, A., Lourie, S. A., Martin, K. D., McManus, E., Molnar, J., Recchia, C. A., and Robertson, J.: Marine Ecoregions of the World: A Bioregionalization of Coastal and Shelf Areas, Bioscience, 57, 573-582, 2007.

Spiess, F.: The Meteor expedition, Vertag von Dietrich Reimer, Berlin, 1928.

Squires, D. F.: Deep-water coral structure on the Campbell Plateau, New Zealand, Deep-Sea Res., 12, 785-788, 1965. 
Stefanescu, C., Morales-Nin, B., and Massutí, E.: Fish assemblages on the slope in the Catalan Sea (Western Mediterranean): influence of a submarine canyon, J. Mar. Biol. Assoc. UK, 74, 499512,1994

Stone, R.: Coral habitat in the Aleutian Islands of Alaska: depth distribution, fine-scale species associations, and fisheries interactions, Coral Reefs, 25, 229-238, 2006.

Storey, B. C.: The role of mantle plumes in continental breakup: case histories from Gondwanaland, Nature, 337, 301-308, 1995.

Stramma, L., Johnson, G. C., Sprintall, J., and Mohrholz, V.: Expanding Oxygen-Minimum Zones in the Tropical Oceans, Science, 320, 655-658, 2008.

Struck, T., Schult, N., Kusen, T., Hickman, E., Bleidorn, C., McHugh, D., and Halanych, K.: Annelid phylogeny and the status of Sipuncula and Echiura, BMC Evol. Biol., 7, 57, 2007.

Stuart, C. T., Rex, M. A., and Etter, R. J.: Large-scale spatial and temporal patterns of deep-sea benthic species diversity, in: Ecosystems of the Deep Oceans, edited by: Tyler, P. A., Ecosystems of the World, Elsevier, Amsterdam, 295-313 pp., 2003.

Sweeney, J. B.: A pictorial history of oceanographic submersibles, Crown Publishers Inc., New York, 1970.

Tarasov, V. G., Gebruk, A. V., Mironov, A. N., and Moskalev, L. I.: Deep-sea and shallow-water hydrothermal vent communities: two different phenomena?, Chem. Geol., 224, 5-39, 2005.

Taviani, M., Freiwald, A., and Zibrowius, H.: Deep coral growth in the Mediterranean Sea: an overview, in: Cold-Water Corals and Ecosystems, edited by: Freiwald, A. and Roberts, J. M., Erlangen Earth Conference Series, Springer, Berlin, Heidelberg, 137-156, 2005.

Tendal, O. S.: The North Atlantic distribution of the octocoral Paragorgia arborea (L., 1758) (Cnidaria, Anthozoa), Sarsia, 77, 213-217, 1992.

Thiel, H.: The size structure of the deep-sea benthos, Internationale Revue der gesamte Hydrobiology, Berlin, 60, 575-606, 1975.

Thiel, H.: Structural aspects of the deep-sea benthos, Ambio, 6, 25-31, 1979.

Thiel, H.: Meiobenthos and nanobenthos of the deep-sea, in: Deepsea Biology, editec by: Rowe, G., Wiley, New York, 167-230, 1983.

Thiel, H., Pfannkuche, O., Schriever, G., Lochte, K., Gooday, A. J., Hemleben, R. E. G., Mantoura, C. M., Turley, J. W., Patching, J. W., and Riemann, F.: Phytodetritus on the deep-sea floor in a central oceanic region of the Northeast Atlantic, Biol. Oceanogr., 6, 203-239, 1990.

Thiel, H.: Anthropogenic impacts on the deep sea, in: Ecosytems of the World, Vol. 28, Ecosystems of the Deep Ocean, edited by: Tyler, P. A., Elsevier, Amsterdam, 427-472, 2003.

Thistle, D.: The role of biologically produced habitat heterogeneity in deep-sea diversity maintenance, Deep-Sea Res., 30, 1235 1245, 1983.

Thistle, D. and Sherman, K. M.: The nematode fauna of a deep-sea site exposed to strong near-bottom currents, Deep-Sea Res., 32, 1077-1088, 1985.

Thistle, D., Yingst, J. Y., and Fauchald, K.: A deep-sea benthic community exposed to strong bottom currents on the Scotian Rise (Western Atlantic), Mar. Geol., 66, 91-112, 1985.

Thistle, D. and Wilson, G. D. F.: A hydrodynamically modified, abyssal isopod fauna, Deep-Sea Res., 34, 73-87, 1987.
Thistle, D.: A temporal difference in harpacticoid-copepod abundance at a deep-sea site: caused by benthic storms?, Deep-Sea Res. Pt. I, 32, 1015-1020, 1988.

Thistle, D. and Eckman, J. E.: The effect of a biologically produced structure on the benthic copepods of a deep-sea site, Deep-Sea Res., 37, 541-554, 1990.

Thistle, D., Ertman, S. C., and Fauchald, K.: The fauna of the HEBBLE site: patterns in standing stock and sediment-dynamic effects, Mar. Geol., 99, 413-422, 1991.

Thistle, D. and Wilson, G. D. F.: Is the HEBBLE isopod fauna hydrodynamically modified - a second test, Deep-Sea Res., 43, 545-554, 1996.

Thistle, D.: The deep-sea floor: an overview, in: Ecosystems of the World, Vol. 28, Ecosystems of the Deep Oceans, edited by: Tyler, P. A., Elsevier, Amsterdam, 5-39, 2003.

Thomas, E. and Gooday, A. J.: Cenozoic deep-sea benthic foraminifers: Tracers for changes in oceanic productivity?, Geology, 24, 355-358, 1996.

Thomas, E. and Shackleton, N. J.: The Paleocene-Eocene benthic foraminiferal exctinction and stable isotope anomalies, in: Correlation in the early paleocene in Northwestern Europe, edited by: Knox, R. W. O. B., Corfield, R. M., and Dunnay, R. E., Geol. Soc. Special Publication, 101, 401-441, 1996.

Thomas, E.: Cenozoic mass extinctions in the deep sea: What perturbs the largest habitat on Earth?, in: Large Ecosystem Perturbations: Causes and Consequances, edited by: Monechi, S., Coccioni, R., and Rampino, M. R., Geol. Soc. America Special Paper, 424, 1-23, 2007.

Thomson, C. W.: The Depths of the Sea, McMillan and Co., London, 1873.

Thomson, M. R. A.: Geological and palaeoenvironmental history of the Scotia Sea region as a basis for biological interpretation, Deep-Sea Res. Pt. II, 51, 1467-1487, 2004.

Tietjen, J. H.: Distribution and species diversity of deep-sea nematodes off North Carolina, Deep-Sea Res., 23, 755-768, 1976.

Tietjen, J. H.: Ecology of deep-sea nematodes from the Puerto Rico Trench area and Hatteras Abyssal Plain, Deep-Sea Res., 36, 1579-1594, 1989.

Tittensor, D. P., Baco, A. R., Brewin, P. E., Clark, M. R., Consalvey, M., Hall-Spencer, J., Rowden, A. A., Schlacher, T., Stocks, K. I., and Rogers, A. D.: Predicting global habitat suitability for corals on seamounts, J. Biogeogr., 36, 1111-1128, 2009.

Tizard, T. H., Moseley, H. N., Buchanan, J. Y., and Murray, J.: Challenger Report: Narrative of the cruise of H.M.S. Challenger, with a general account of the scientific results of the expedition, partly illustrated by: Wild, J. J., Her Majesty's Stationery Office, 1110 pp., 1885.

Todo, Y., Kitazato, H., Hashimoto, J., and Gooday, A. J.: Simple foraminifera flourish at the ocean's deepest point, Science, 307, 689, 2005.

Tomczak, M. and Godfrey, J. S.: Regional Oceanography: An Introduction, Pergamon, London, 422 pp., 1994.

Tselepides, A. and Lampadariou, N.: Deep-sea meiofaunal community structure in the Eastern Mediterranean: are trenches benthic hotspots?, Deep-Sea Res. Pt. I, 51, 833-847, 2004.

Tudhope, A. W. and Scoffin, T. P.: Processes of sedimentation in Gollum Channel, Porcupine Seabight: submersible observations and sedimentation analyses: Trans. Roy. Soc. Edinburgh, Earth Sci., 86, 49-55, 1995. 
Tunnicliffe, V.: The Nature and Origin of the Modern Hydrothermal Vent Fauna, Palaios, 7, 338-350, 1992.

Tunnicliffe, V., Fowler, C. M. R., and McArthur, A. G.: Plate tectonic history and hot vent biogeography, in: Tectonic, Magmatic, Hydrothermal and Biological Segmentation of Mid-ocean ridges, edited by: MacLeod, C. J., Tyler, P. A., Young, C. M., and Walker, C. L., Geol. Soc. Lond., 225-238, 1996.

Tunnicliffe, V., Embley, R. W., Holden, J. F., Butterfield, D. A., Massoth, G. J., and Juniper, S. K.: Biological colonization of new hydrothermal vents following an eruption on Juan de Fuca Ridge, Deep-Sea Res. Pt. I, 44, 1627-1644, 1997.

Tunnicliffe, V., McArthur, A. G., and McHugh, D.: A biogeographical perspective of the deep-sea hydrothermal vent fauna, Adv. Mar. Biol., 34, 353-442, 1998.

Tunnicliffe, V., Juniper, K. S., and Sibuet, M.: Reducing environments of the deep-sea floor, in: Ecosystems of the World, Vol. 28, Ecosystems of the deep oceans, edited by: Tyler, P. A., Elsevier, London, 81-110, 2003.

Turchetto, M., Boldrin, A., Langone, L., Miserocchi, S., Tesi, T., and Foglini, F.: Particle transport in the Bari Canyon (southern Adriatic Sea), Mar. Geol., 246, 231-247, 2007.

Tursi, A., Mastrototaro, F., Matarrese, A., Maiorano, P., and D'onghia, G.: Biodiversity of the white coral reefs in the Ionian Sea (Central Mediterranean), Chem. Ecol., 20, 107-116, 2004.

Tyler, P. A.: Seasonality in the deep-sea, Oceanogr. Mar. Biol., 26, 227-258, 1988.

Tyler, P. A. and Ramírez-Llodra, E.: Larval and reproductive strategies on European continental margins, in: Ocean Margin Systems, edited y: Billett, D. S. M., Wefer, G., Hebbeln, D., Jorgensen, B. B., Schluter, M., and Van Weering, T. C. E., Springer, Berlin, 339-350, 2002.

Tyler, P. A., German, C. R., Ramirez-Llodra, E., and Van Dover, C. L.: Understanding the biogeography of chemosynthetic ecosystems, Oceanol. Acta, 25, 227-241, 2003.

Uchida, R. N. and Tagami, D. T.: Groundfish fisheries and research in the vicinity of seamounts in the north Pacific ocean, Mar. Fish. Rev., 46, 1-17, 1984.

UNEP-WCMC: Deep-sea biodiversity and ecosystems: A scoping report for their socio-economy, management and governance, 184, 2007.

Unger, M. A., Harvey, E., Vadas, G. G., and Vecchione, M.: Persistent pollutants in nine species of deep-sea cephalopods, Mar. Pollut. Bull., 56, 1486-1512, 2008.

Van Dover, C. L.: The Ecology of Deep-Sea Hydrothermal Vents, Princeton University Press, Princeton, 424 pp., 2000.

Van Dover, C. L., German, C. R., Speer, K. G., Parson, L. M., and Vrijenhoek, R. C.: Evolution and biogeography of deep-sea vent and seep invertebrates, Science, 295, 1253-1257, 2002.

Van Dover, C. L.: The biological environment of polymetallic sulphides deposits, the potential impact of exploration and mining on this environment, and data required to establish environmental baselines in exploration areas, in: Polymetallic Sulphides and Cobalt-Rich Ferromanganese Crusts Deposits: Establishment of Environmental Baselines and an Associated Monitoring Programme During Exploration, Proceedings of the International Seabed Authority's Workshop held in Kingston, Jamaica, 6-10 September 2004; International Seabed Authority, Kingston, Jamaica, 2007.
Vanaverbeke, J., Martinez-Arbizu, P., Dahms, H. U., and Schminke, H. K.: The metazoan meiobenthos along a depth gradient in the Arctic Laptev Sea with special attention to nematode communities, Polar Biol., 18, 391-401, 1997a.

Vanaverbeke, J., Soetaert, K., Heip, C., and Vanreusel, A.: The metazoan meiobenthos along the continental slope of the Goban Spur (NE Atlantic), J. Sea Res., 38, 93-107, 1997b.

Vanhove, S., Arntz, W., and Vincx, M.: Comparative study of the nematode communities on the southeastern Weddell Sea shelf and slope (Antarctica), Mar. Ecol.-Prog. Ser., 181, 237-256, 1999.

Vanhove, S., Vermeeren, H., and Vanreusel, A.: Meiofauna towards the South Sandwich Trench $(750-6300 \mathrm{~m})$, focus on nematodes, Deep-Sea Res. Pt. II, 51, 1665-1687, 2004.

Vanreusel, A., Clough, L., Jacobsen, K., Ambrose, W., Jivaluk, J., Ryheul, V., Herman, R., and Vincx, M.: Meiobenthos of the central Arctic Ocean with special emphasis on nematode community structure, Deep-Sea Res. Pt. I, 47, 1855-1879, 2000.

Vanreusel, A., Fonseca, G., Danovaro, R., Da Silva, S., Esteves, A. M., Ferrero, T. G. G., Galtsova, V., Gambi, C., da Fonseca Genevois, V., Ingels, J., Ingole, B., Lampadariou, N., Merckx, B., Miljutin, D., Miljutina, M., Muthumbi, A., Netto, S., Portnova, D., Radziejewska, T., Raes, M., Tchesunov, A., Vanaverbeke, J., Van Gaever, S., Venekey, V., Bezerra, T. N., Flint, H., Copley, J., Pape, E., Zeppilli, D., Arbizu Martinez, P., and Galeron, J.: The contribution of deep-sea macrohabitat heterogeneity to global nematode diversity, Mar. Ecol., 31, 6-20, 2010.

Vecchione, M., Bergstad, O. A., Byrkjedal, I., Falkenhaug, R., Gebruk, A. V., Godø, O. R., Gislason, A., Heino, M., Høines, Å. S., Menezes, G., Piatkowski, U., Priede, I. G., Skov, H., Søiland, H., Sutton, T., and de Lange Wenneck, T.: Biodiversity Patterns and Processes on the mid-Atlantic Ridge, in: Life in the World's Oceans: Diversity, Distribution, and Abundance, edited by: McIntyre, A., Chapter 6, Wiley Blackwell, Oxford, 103-121, 2010.

Veillette, J., Sarrazin, J., Gooday, A. J., Galéron, J., Caprais, J.-C., Vangriesheim, A., Etoubleau, J., Christiand, J. R., and Juniper, S. K.: Ferromanganese nodule fauna in the Tropical North Pacific Ocean: Species richness, faunal cover and spatial distribution, Deep-Sea Res. Pt. I, 54, 1912-1935, 2007.

Vetter, E. W. and Dayton, P. K.: Organic enrichment by macrophyte detritus and abundance patterns of megafaunal populations in submarine canyons, Mar. Ecol.-Prog. Ser., 186, 137-148, 1999.

Vetter, E. W., Smith, C. R., and De Leo, F. C.: Megafaunal abundance and diversity in submarine canyons on the oceanic islands of Hawaii, Mar. Ecol., 31, 183-200, 2010.

Vincx, M., Bett, B. J., Dinet, A., Ferrero, T., Gooday, A. J., Lambshead, P. J. D., Pfannkuche, O., Soltwedel, T., and Vanreusel, A.: Meiobenthos of the deep Northeast Atlantic, Adv. Mar. Biol., 30, 2-88, 1994.

Vine, F. J. and Matthews, D. H.: Magnetic anomalies over oceanic ridges, Nature, 199, 947-949, 1963.

Vinogradov, G. M.: Vertical distribution of macroplankton at the Charlie-Gibbs Fracture Zone (North Atlantic), as observed from the manned submersible Mir-1, Mar. Biol., 146, 325-331, 2005.

Vinogradova, N. G.: The geographical distribution of the abyssal and hadal (ultra-abyssal fauna in relation to the vertical zonation of the ocean, Sarsia, 64, 41-49, 1979. 
Vinogradova, N. G.: Zoogeography of the Abyssal and Hadal Zones, in: The biogeography of the oceans, edited by: Gebruk, A. V., Southward, E. C., and Tyler, P. A., Adv. Mar. Biol., 32, 325-387, 1997.

Vitiello, P.: Peuplements de nematodes marins des fonds envasés de Provence II. Fonds détritiques invasés et vases bathyales, Ann. Inst. Oceanogr. Paris, 52, 283-311, 1976.

Wallich, G. C.: The North Atlantic seabed - Comprising a diary of the voyage of HMS Bulldog in 1860 and observations on the presence of animal life and the formation and nature of organic deposits at great depths in the ocean, Published with the sanction of Lords Commisoners of the Admiralty, 1862.

Wareham, V. E. and Edinger, E. N.: Distribution of deep-sea corals in the Newfoundland and Labrador region, Northwest Atlantic Ocean, B. Mar. Sci., 81, 289-313, 2007.

Webb, T. J., Vanden Berghe, E., and O'Dor, R.: Biodiversity's big wet secret: The global distribution of marine biological records reveals chronic under-exploration of the deep pelagic ocean, PLOS One, 5, e10223, doi:10.1371/journal.pone.0010223, 2010.

Weishappel, J. B. F. and Svavarsson, J.: Benthic amphipods (Crustacea: Malacostraca) in Icelandic waters: diversity in relation to faunal patterns from shallow to intermediate deep Arctic and North Atlantic Oceans, Mar. Biol., 131, 133-143, 1998.

Widder, E. A.: Bioluminescence and the pelagic visual environment, Mar. Freshw. Behav. Phy., 35, 1-26, 2002.

Widder, E. A.: Bioluminescence in the ocean: Origins of biological, chemical, and ecological diversity, Science, 328, 704-708, 2010.

Wienberg, C., Beuck, L., Heidkamp, S., Hebbeln, D., Freiwald, A., Pfannkuche, O., and Monteys, X.: Franken Mound: facies and biocoenoses on a newly-discovered "carbonate mound" on the western Rockall Bank, NE Atlantic, Facies, 54, 1-24, 2008.

Wigham, B., Tyler, P. A., and Billett, D. S. M.: Reproductive biology fo the abyssal holothurian Amperima rosea: an oppotunistic response to variable flux of surface derived organic matter?, J. Mar. Biol. Assoc. UK, 83, 175-188, 2003.

Wilson, J. B.: The distribution of the coral Lophelia pertusa (L.) ( $L$. prolifera (Pallas)) in the north-east Atlantic, J. Mar. Biol. Assoc. UK, 59, 149-164, 1979.

Wilson, G. D.: Variation in the Deep-Sea Isopod Eurycope iphthima (Asellota, Eurycopidae): Depth Related Clines in Rostral Morphology and in Population Structure, J. Crustacean Biol., 3, 127-140, 1983.

Wilson, G. and Hessler, R.: The effects of manganese nodule test mining on the benthic fauna in the North Equatorial Pacific, in: Environmental Effects of Deep-Sea Dredging, Final Report to the National Oceanic and Atmospheric Administration, edited by: Spiess, F. N., Hessler, R., Wilson, G., and Weydert, M., Scripps Institution of Oceanography, La Jolla, California, 24-86, 1987.
Wilson, S. P. and Costello, M. J.: Predicting future discoveries of European marine species by using a non-homogenous renewal process, J. Roy. Stat. Soc. C., 54, 897-918, 2005.

Wisshak, M., Neumann, C., Jakobsen, J., and Freiwald, A.: The "living-fossil community" of the cyrtocrinid Cyathidium foresti and the deep-sea oyster Neopycnodonte zibrowii (Azores Archipelago), Palaeogeogr. Palaeoecol., 271, 77-83, 2009.

Witman, J. D., Etter, R. J., and Smith, F.: The relationship between regional and local species diversity in marine benthic communities: a global perspective, P. Natl. Acad. Sci., 101, 15664-15669, 2004.

Wolff, T.: Galathea 2 Report (1957-1961) Scientific Results of The Danish Deep-Sea Expedition Round the World 1950-52, issued by the Galathea committee, 1956.

Wolff, T.: The concept of hadal or ultra abyssal fauna, Deep-Sea Res., 17, 983-1003, 1970.

Worm, B., Lotze, H. K., and Myers, R.: Predator diversity hotspots in the blue ocean, P. Natl. Acad. Sci. USA, 100, 9884-9888, 2003.

Woulds, C., Cowie, G. L., Levin, L. A., Andersson, J. H., Middelburg, J. J., Vandewiele, S., Lamont, P. A., Larkin, K. E., Gooday, A. J., Schumacher, S., Whitcraft, C., Jeffreys, R. M., and Schwartz, M.: Oxygen as a control on seafloor biological communities and their roles in sedimentary carbon cycling, Limnol. Oceanogr., 52, 1698-1709, 2007.

Wyrtki, K.: The oxygen minima in relation to ocean circulation, Deep-Sea Res., 9, 11-23, 1962.

WWF/IUCN: The Mediterranean deep-sea ecosystems: an overview of their diversity, structure, functioning and anthropogenic impacts, Málaga (IUCN) and Rome (WWF), 64 pp., 2004.

Yool, A., Martin, A. P., Fernández, C., and Clark, D. R.: The significance of nitrification for oceanic new production, Nautre, 477, 999-1002, 2007.

Young, C. M.: Reproduction, Development and Life History Traits, in: Ecosystems of the World, Vol. 28, Ecosystems of the Deep Oceans, edited by: Tyler, P. A., Elsevier, London, 381-426, 2003.

Zezina, O. N.: Biogeography of the Bathyal Zone, in: The biogeography of the oceans, edited by: Gebruk, A. V., Southward, E. C., and Tyler, P. A., Adv. Mar. Biol., 389-426, 1997.

Zibrowius, H.: Les Scleractiniairies de la Mediterranee et de l'Atlantic nord-oriental, Mem. Inst. Oceanogr. Monaco, 11, 226 pp., 1980. 